Prepared in cooperation with the City of Cedar Rapids, lowa

\title{
Transport of Nitrogen and Phosphorus in the Cedar River Basin, lowa and Minnesota, 2000-15
}
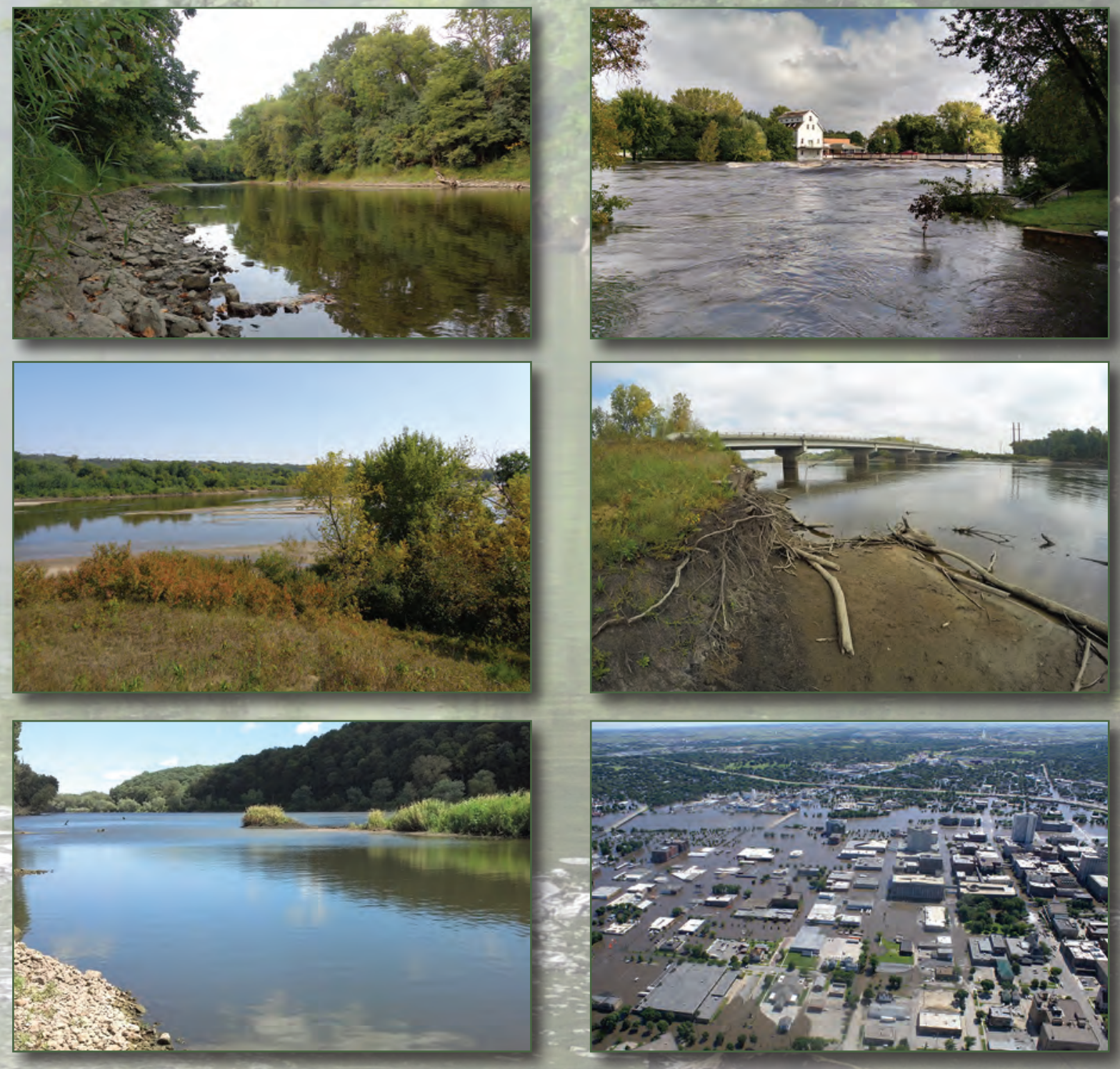

Scientific Investigations Report 2018-5090

U.S. Department of the Interior U.S. Geological Survey 

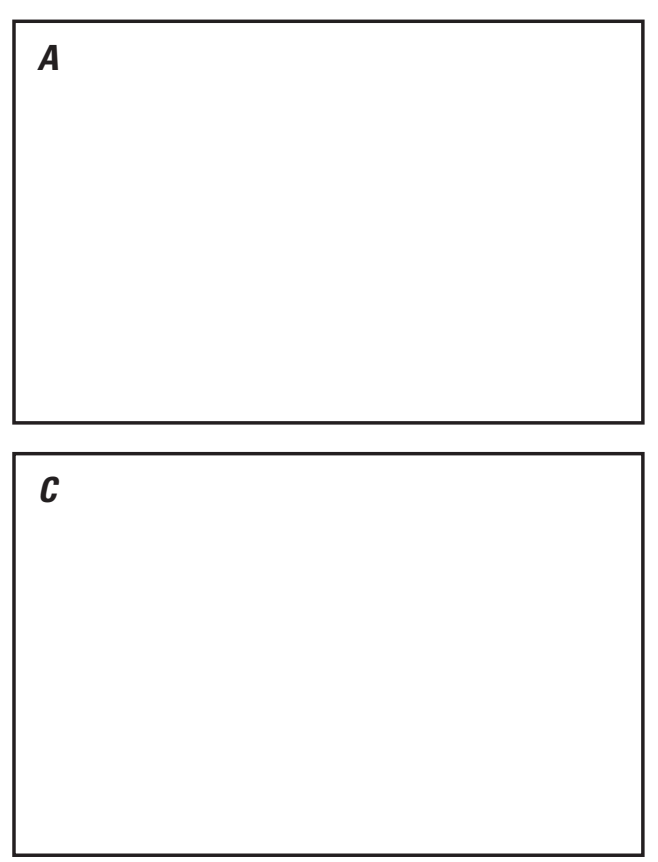

\section{$E$}

Cover photographs. $\quad A$, Winnebago River at Mason City, lowa. Credit: S.J. Kalkhoff, U.S. Geological Survey (USGS). B, Flooding on the Shell Rock River at Shellrock, lowa. Credit: Clint Van Schepen, USGS. C, Cedar River near Urbana, lowa. Credit: S.J. Kalkhoff, USGS. D, Low flow in the Cedar River near Palo, lowa. Credit: S.J. Kalkhoff, USGS. E, Cedar River in Cedar Rapids, lowa. Credit: S.J. Kalkhoff, USGS. F, A record flood in 2008 covered large areas of the city of Cedar Rapids, lowa. Credit: City of Cedar Rapids (used with permission).

Background photograph. Cedar River State Water Trail in Austin Township, south of Austin, Minnesota. Credit: Tim Ruzek, Mower County, Minnesota Soil and Water Conservation District (used with permission). 


\section{Transport of Nitrogen and Phosphorus in the Cedar River Basin, lowa and Minnesota, 2000-15}

By Stephen J. Kalkhoff

Prepared in cooperation with the City of Cedar Rapids, lowa

Scientific Investigations Report 2018-5090 


\title{
U.S. Department of the Interior \\ RYAN K. ZINKE, Secretary
}

\author{
U.S. Geological Survey \\ James F. Reilly II, Director
}

U.S. Geological Survey, Reston, Virginia: 2018

For more information on the USGS - the Federal source for science about the Earth, its natural and living resources, natural hazards, and the environment-visit https://www.usgs.gov or call 1-888-ASK-USGS.

For an overview of USGS information products, including maps, imagery, and publications,

visit https://store.usgs.gov.

Any use of trade, firm, or product names is for descriptive purposes only and does not imply endorsement by the U.S. Government.

Although this information product, for the most part, is in the public domain, it also may contain copyrighted materials as noted in the text. Permission to reproduce copyrighted items must be secured from the copyright owner.

Suggested citation:

Kalkhoff, S.J., 2018, Transport of nitrogen and phosphorus in the Cedar River Basin, lowa and Minnesota, 2000-15: U.S. Geological Survey Scientific Investigations Report 2018-5090, 44 p., https://doi.org/10.3133/sir20185090.

ISSN 2328-031X (print)

ISSN 2328-0328 (online) 


\section{Acknowledgments}

The author would like to acknowledge the City of Cedar Rapids Utilities Water Division for providing support for this project. Long-term monitoring data were collected from the Cedar River in Minnesota by the Minnesota Pollution Control Agency and at lowa sites by lowa State Hygienic Laboratory personnel for the lowa Department of Natural Resources. Monthly water samples for the lowa Department of Natural Resources ambient network were analyzed by the University of lowa State Hygienic Laboratory. Assistance in obtaining Minnesota Pollution Control Agency data was provided by Bill Thompson from the Minnesota Pollution Control Agency Rochester, Minnesota, office.

Water-quality samples also were collected and streamflow was measured by personnel from the U.S. Geological Survey. Casey Lee and Erik Smith of the U.S. Geological Survey reviewed initial drafts of this report and provided invaluable comments and suggestions that greatly improved the report. 



\section{Contents}

Acknowledgments ……...................................................................................................................

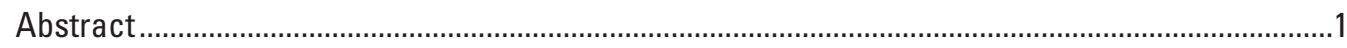

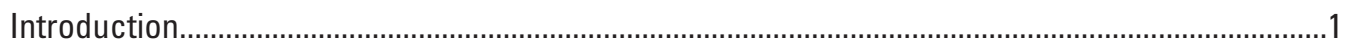

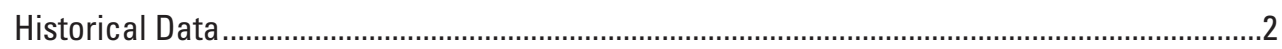

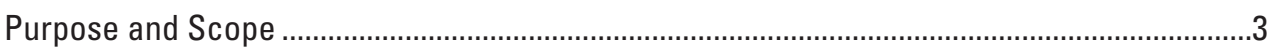

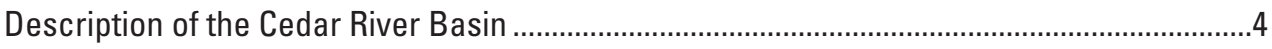

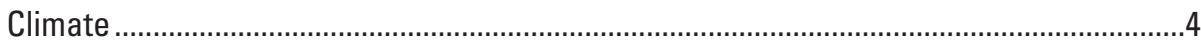

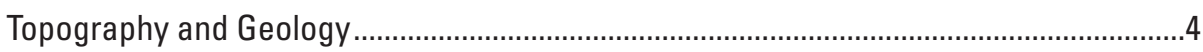

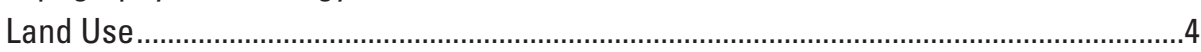

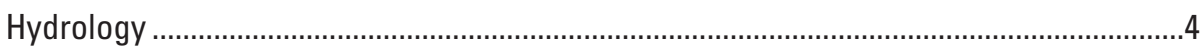

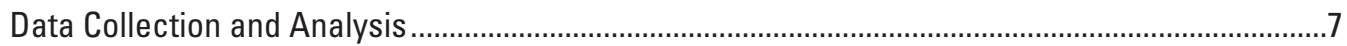

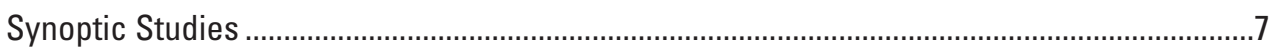

Timing of Sample Collection................................................................................................

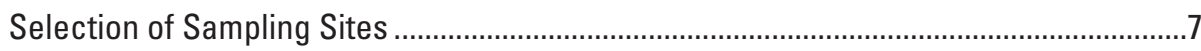

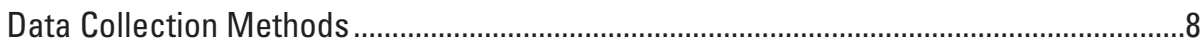

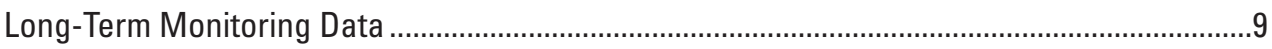

lowa Department of Natural Resources Monitoring .........................................................

Minnesota Pollution Control Agency......................................................................... 10

U.S. Geological Survey Continuous Nitrate Monitoring .................................................11

Long-Term Monitoring Subbasins ......................................................................................

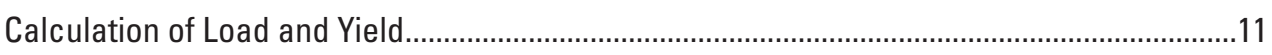

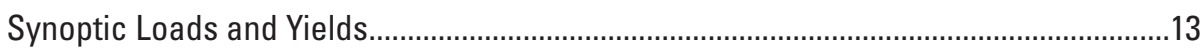

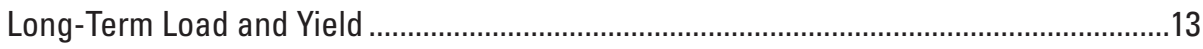

Calculation of Annual Subbasin Loads and Yields .......................................................15

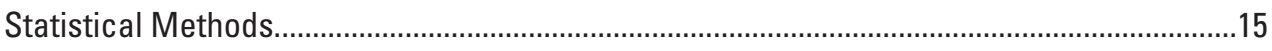

Transport of Nitrogen and Phosphorus During Base-Flow Periods................................................16

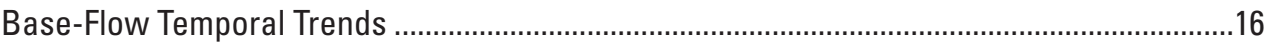

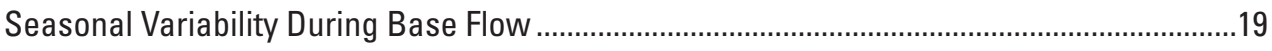

Spatial Differences During Base-Flow Conditions.................................................................19

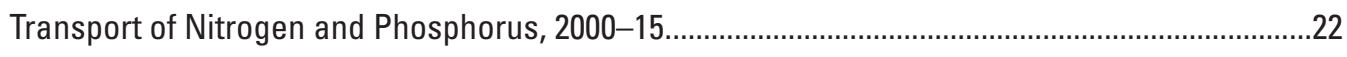

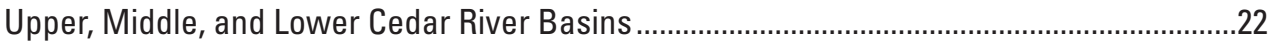

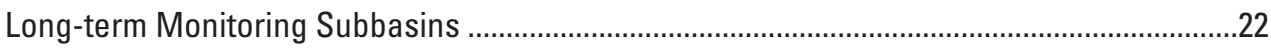

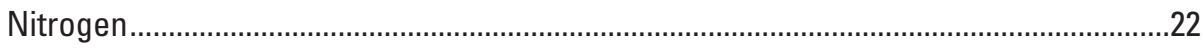

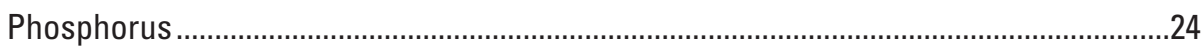

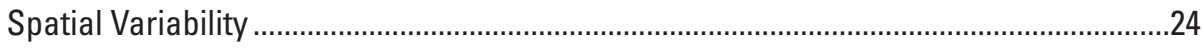

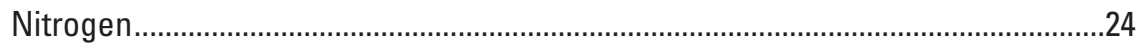

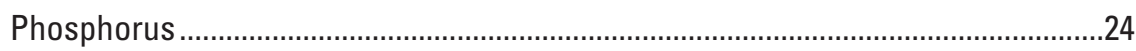

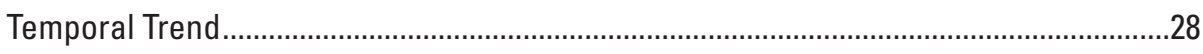

Transport in the Main Stem Upper Cedar River Subbasin ....................................................29

Relation Between Nutrient Transport and Runoff ...................................................................

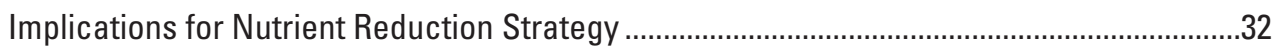

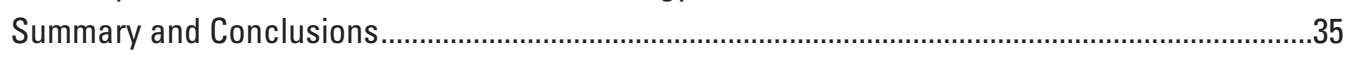

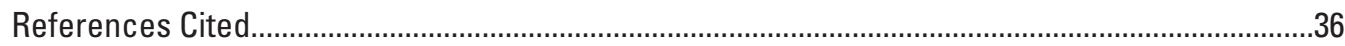


Appendix 1. Long-Term Monitoring Data from the Cedar River Basin, lowa and Minnesota.

\section{Figures}

1. Graph showing historical nitrate concentrations in the Cedar River at Cedar Rapids, lowa

2. Graph showing nitrate plus nitrite nitrogen concentrations in the Cedar River at five main-stem sites, 1984-85

3. Map showing the Cedar River Basin in lowa and Minnesota showing the Upper, Middle, and Lower Cedar River Basins and the locations of synoptic and long-term monitoring sites

4. Graph showing annual average rainfall in the Cedar River Basin, lowa and Minnesota, 2000-15

5. Graph showing annual mean discharge and runoff from the Cedar River Basin .............6

6. Map showing long-term monitoring subbasins and their respective sampling sites in the Cedar River Basin, lowa and Minnesota.

7. Graphs showing observed daily total phosphorus and Kjeldahl nitrogen load in relation to the modeled daily load in the Cedar River near Austin, Minnesota, and in the West Fork Cedar River near Finchford, lowa, 2000-15.

8. Maps showing nitrogen yield during spring (2001, 2011), fall $(2000,2010)$, and dry fall $(2002,2012)$ base-flow conditions in Cedar River subbasins

9. Maps showing phosphorus yield during spring $(2001,2011)$, fall $(2000,2010)$, and dry fall $(2002,2012)$ base-flow conditions in Cedar River subbasins.

10. Maps showing spatial variability of the average annual yield of nitrate nitrogen and total nitrogen in long-term monitoring subbasins in the Cedar River Basin, 2000-15

11. Maps showing spatial variability of the average annual yield of dissolved orthophosphate and total phosphorus in long-term monitoring subbasins in the Cedar River Basin, 2000-15

12. Graphs showing the trend in estimated annual total nitrogen and total phosphorus loads in the Upper Winnebago River and Wolf Creek from 2000 through 2015

13. Graph showing the trend in the transport of total phosphorus from the Main Stem Middle Cedar River and Lower Cedar River subbasins, 2000-15.

14. Graph showing a comparison of the average annual total phosphorus load between the first half (2000-7) and second half (2008-15) of the study in the Main Stem Middle Cedar and Lower Cedar River Basins

15. Map showing spatial variability of the average annual stream runoff from long-term monitoring subbasins in the Cedar River Basin, 2000-15.

16. Graphs showing the relation between annual runoff and total nitrogen and total phosphorus yield in the Upper Winnebago River and Wolf Creek subbasins, 2000-15

17. Graphs showing the relation between stream runoff and total nitrogen and total phosphorus yield from long-term monitoring Cedar River subbasins, 2000-15.....

18. Graphs showing the relation between annual runoff and total nitrogen and total phosphorus yields with current conditions (2000-15) and theoretical 20- and 45-percent yield reductions from the Wolf Creek subbasin. 


\section{Tables}

1. Description of the Cedar River Basin in lowa and Minnesota.............................................6

2. Flow conditions in the Cedar River Basin during base-flow synoptic

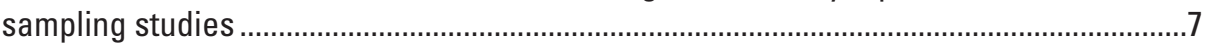

3. Synoptic monitoring sites in the Cedar River Basin.............................................................

4. Long-term monitoring sites in the Cedar River Basin, lowa and Minnesota, 2000-15.

5. Subbasins and their respective sampling sites in the Cedar River Basin, lowa and Minnesota

6. Methods used to estimate nitrogen and phosphorus loads at the long-term monitoring sites in the Cedar River Basin, 2000-15.

7. Seasonal variability in nitrogen and phosphorus concentration and yield at synoptic sampling sites in the Cedar River Basin, 2000-12.

8. Summary of daily nitrogen and phosphorus yields from synoptic subbasins in the Cedar River Basin during the early 2000s in relation to those during the early 2010s

9. Summary of annual nitrogen and phosphorus load and yield from the Upper, Middle, and Lower Cedar River Basins, 2000-15

10. Nitrogen and phosphorus transport from long-term monitoring subbasins in the Cedar River Basin, lowa and Minnesota, 2000-15.

11. Summary of annual nutrient load and yield in Minnesota Cedar River and Main Stem Upper Cedar River subbasins, 2007-15

12. Linear relation between annual stream runoff and annual nitrogen and phosphorus yield in Cedar River subbasins, 2000-15

13. Estimated nitrogen and phosphorus loads transported from long-term monitoring Cedar River subbasins to meet 20- and 45-percent nutrient reduction goals

1.1. Source of long-term monitoring data ......................................................................

1.2. Annual nutrient loads in long-term monitoring subbasins, $2000-15$.............................43

1.3. Annual nutrient yields in long-term monitoring subbasins, 2000-15...............................4 


\section{Conversion Factors}

U.S. customary units to International System of Units

\begin{tabular}{|c|c|c|}
\hline Multiply & By & To obtain \\
\hline \multicolumn{3}{|c|}{ Length } \\
\hline inch (in.) & 2.54 & centimeter $(\mathrm{cm})$ \\
\hline foot $(\mathrm{ft})$ & 0.3048 & meter $(\mathrm{m})$ \\
\hline mile (mi) & 1.609 & kilometer (km) \\
\hline \multicolumn{3}{|c|}{ Area } \\
\hline acre & 4,047 & square meter $\left(\mathrm{m}^{2}\right)$ \\
\hline acre & 0.4047 & hectare (ha) \\
\hline acre & 0.4047 & square hectometer $\left(\mathrm{hm}^{2}\right)$ \\
\hline acre & 0.004047 & square kilometer $\left(\mathrm{km}^{2}\right)$ \\
\hline square foot $\left(\mathrm{ft}^{2}\right)$ & 929.0 & square centimeter $\left(\mathrm{cm}^{2}\right)$ \\
\hline square foot $\left(\mathrm{ft}^{2}\right)$ & 0.09290 & square meter $\left(\mathrm{m}^{2}\right)$ \\
\hline square inch $\left(\mathrm{in}^{2}\right)$ & 6.452 & square centimeter $\left(\mathrm{cm}^{2}\right)$ \\
\hline section (640 acres or 1 square mile) & 259.0 & square hectometer $\left(\mathrm{hm}^{2}\right)$ \\
\hline square mile $\left(\mathrm{mi}^{2}\right)$ & 259.0 & hectare (ha) \\
\hline square mile $\left(\mathrm{mi}^{2}\right)$ & 2.590 & square kilometer $\left(\mathrm{km}^{2}\right)$ \\
\hline \multicolumn{3}{|c|}{ Volume } \\
\hline gallon (gal) & 3.785 & liter $(\mathrm{L})$ \\
\hline gallon (gal) & 0.003785 & cubic meter $\left(\mathrm{m}^{3}\right)$ \\
\hline cubic foot $\left(\mathrm{ft}^{3}\right)$ & 0.02832 & cubic meter $\left(\mathrm{m}^{3}\right)$ \\
\hline acre-foot (acre-ft) & 1,233 & cubic meter $\left(\mathrm{m}^{3}\right)$ \\
\hline \multicolumn{3}{|c|}{ Flow rate } \\
\hline cubic foot per second $\left(\mathrm{ft}^{3} / \mathrm{s}\right)$ & 0.02832 & cubic meter per second $\left(\mathrm{m}^{3} / \mathrm{s}\right)$ \\
\hline inch per year (in/yr) & 25.4 & millimeter per year $(\mathrm{mm} / \mathrm{yr})$ \\
\hline \multicolumn{3}{|c|}{ Mass } \\
\hline ounce, avoirdupois (oz) & 28.35 & $\operatorname{gram}(\mathrm{g})$ \\
\hline pound, avoirdupois (lb) & 0.4536 & kilogram (kg) \\
\hline ton, short $(2,000 \mathrm{lb})$ & 0.9072 & metric ton $(\mathrm{t})$ \\
\hline ton, long $(2,240 \mathrm{lb})$ & 1.016 & metric ton $(\mathrm{t})$ \\
\hline \multicolumn{3}{|c|}{ Application rate } \\
\hline pound per acre per year ([lb/acre]/yr) & 1.121 & kilogram per hectare per year $([\mathrm{kg} / \mathrm{ha}] / \mathrm{yr})$ \\
\hline
\end{tabular}

Temperature in degrees Fahrenheit $\left({ }^{\circ} \mathrm{F}\right)$ may be converted to degrees Celsius $\left({ }^{\circ} \mathrm{C}\right)$ as follows:

$$
{ }^{\circ} \mathrm{C}=\left({ }^{\circ} \mathrm{F}-32\right) / 1.8 .
$$




\section{Supplemental Information}

Load is the rate of constituent transport, as measured by dry mass or volume, that passes a cross section in a given time. It is calculated in units of tons per day as follows: concentration (in milligrams per liter) $\times$ discharge (in cubic feet per second) $\times 0.0027$.

Water year is the 12-month period October 1 through September 30 . The water year is designated by the calendar year in which it ends and which includes 9 of the 12 months. Thus, the year beginning on October 1, 2014, and ending September 30, 2015, is called the "2015 water year."

\section{Abbreviations}

EPA U.S. Environmental Protection Agency

IADNR lowa Department of Natural Resources

MPCA Minnesota Pollution Control Agency

SHL University of lowa State Hygienic Laboratory

USGS U.S. Geological Survey

WRTDS Weighted Regressions on Time, Discharge, and Season 



\title{
Transport of Nitrogen and Phosphorus in the Cedar River Basin, lowa and Minnesota, 2000-15
}

\author{
By Stephen J. Kalkhoff
}

\section{Abstract}

Nitrate concentrations in the Cedar River in Iowa and Minnesota have increased from an average of less than 1.0 milligram per liter in the early 1900 s to more than 5.0 milligrams per liter in the 2000s and have resulted in periodic water-quality impairment of the river. Spatial differences and temporal changes in nitrogen and phosphorus transport in the Cedar River Basin are described for the period from 2000 to 2015. Data used to estimate nitrogen and phosphorus transport were collected by the U.S. Geological Survey as part of six base-flow synoptic studies and by the Minnesota Pollution Control Agency and the Iowa Department of Natural Resources as part of their long-term stream and river monitoring programs. The Cedar River transported an annual average of 53,100 tons of total nitrogen and 2,510 tons of total phosphorus during 2000-15. Three subbasins yielded an annual average of more than 30 pounds per acre (lb/acre) of nitrogen to the Cedar River, whereas two subbasins yielded an annual average of less than $20 \mathrm{lb} /$ acre of nitrogen. The average annual total phosphorus yield from the Little Cedar River subbasin $(0.35 \mathrm{lb} / \mathrm{acre})$ was only about 16 percent of the yield from the greatest total phosphorus yielding Lower Cedar River subba$\sin$ (more than $1.0 \mathrm{lb} / \mathrm{acre}$ ). The annual total nitrogen and total phosphorus loads did not change significantly during the study. The relation between annual stream runoff and annual total nitrogen and total phosphorus yields was not spatially uniform across the Cedar River Basin. The Beaver Creek, Black Hawk Creek, and Wolf Creek subbasins yielded the most, and the Main Stem Middle Cedar River, the Lower Cedar River, and the Little Cedar River subbasins yielded the least amount of nitrogen for a given amount of runoff. The Lower Cedar River and Wolf Creek subbasins yielded the most and the West Fork Cedar River and the Little Cedar River subbasins yielded the least phosphorus for a given amount of runoff. The results of this study describe nutrient transport during 2000-15 that can be used to evaluate future progress of nutrient reduction strategies in the Cedar River Basin.

\section{Introduction}

Water in streams and rivers in the Cedar River Basin is an important resource for the citizens of Iowa and Minnesota. Water is used for recreation, cooling water, and a source of municipal and industrial water supply. Municipalities have used the Cedar River as a source of supply by pumping directly from the river and indirectly when pumping from alluvial wells that induce infiltration from the Cedar River (Schulmeyer and Schnoebelen, 1998); however, high nitrate concentrations in the Cedar River may limit its use as a water supply for communities in the watershed and downstream along the Mississippi River. Minnesota and Iowa basins, including the Cedar River Basin, have been identified (Jones and others, 2017; Goolsby and others, 2001) as large contributors of nitrogen to the Gulf of Mexico.

Pumping by the city of Cedar Rapids, Iowa, from municipal wells adjacent to the river induces flow from the Cedar River into the aquifer (Boyd, 1998). Although microbialcatalyzed redox reactions reduce the concentration of nitrate in water infiltrating from the Cedar River into the shallow parts (5-20 $\mathrm{ft}$ below land surface) of the alluvial aquifer, the reduction generally does not occur in water infiltrating to deeper zones of the alluvial aquifer (Boyd, 1999). Because of the small reduction in the aquifer, nitrate concentrations in municipal supply wells often can reflect those in the Cedar River. Supply wells may be shut off when high nitrate concentrations in the river affect supply wells and if the system demands allow it (Tariq Baloch, Water Utility Plant Manager, City of Cedar Rapids, Iowa, Utilities, written commun., February 6, 2018)

The States of Iowa (Iowa Department of Agriculture and Land Stewardship and others, 2014) and Minnesota (Minnesota Pollution Control Agency, 2014) recently have identified methods to reduce nutrient transport to rivers and streams to meet reduction goals. Funds from the City of Cedar Rapids have been provided to assist landowners in the implementation of nutrient reduction strategies. Funds have been awarded to Middle Cedar River watersheds in Black Hawk, Benton, and Tama Counties to support demonstration practices deemed appropriate for a variety of conditions. 


\section{Historical Data}

Results of periodic monitoring of the Cedar River indicate that average nitrate as nitrogen (nitrate) concentrations have increased substantially from an average of less than 1.0 milligram per liter $(\mathrm{mg} / \mathrm{L})$ in $1906-13$ to almost $6.0 \mathrm{mg} / \mathrm{L}$ in the 2000s (fig. 1). The Cedar River first was monitored in the early 1900 s as part of a national program to determine the suitability of waters for use in industrial applications (Dole, 1909). Samples were collected daily from the Cedar River at Cedar Rapids from September 1906 through September 1907 (Dole, 1909). Ten daily samples were composited for analysis of selected major ions including nitrate. During this 2-year period, nitrate concentrations ranged from less than 0.01 to $1.81 \mathrm{mg} / \mathrm{L}$ (Dole, 1909) and averaged $0.65 \mathrm{mg} / \mathrm{L}$ (Clarke, 1924).

Average nitrate concentrations in the Cedar River nearly doubled from 1906-13 to 1944-51 (fig. 1). The average dissolved nitrate concentration in the Cedar River at Cedar Rapids for 1944-51 was $1.59 \mathrm{mg} / \mathrm{L}$ (Hershey, 1955); the maximum concentration was $3.84 \mathrm{mg} / \mathrm{L}$. Yearly averages ranged from $1.17 \mathrm{mg} / \mathrm{L}$ in 1949 (Paulsen, 1953) to $2.13 \mathrm{mg} / \mathrm{L}$ in 1951 (Love, 1956). Discharge from municipal sewage was identified as a contributor to water-quality issues in the Cedar River in the 1950s (Iowa Natural Resources Council, 1955).

By the mid to late 1970s, average nitrate concentrations in the Cedar River were equal to the maximum concentrations measured from 1944 to 1951 . The average nitrate concentration in monthly samples collected from the Cedar River near
Palo, Iowa (about 9 miles upstream from Cedar Rapids), from 1977 to 1980 (U.S. Geological Survey, 1977, 1978, 1979, 1980) was $3.81 \mathrm{mg} / \mathrm{L}$. The nitrate concentration in one sample exceeded the $10-\mathrm{mg} / \mathrm{L}$ drinking water standard (fig. 1).

During the late 1980s, the average dissolved nitrate concentration of monthly samples at five main-stem sites on the Cedar River upstream from Cedar Rapids was $4.79 \mathrm{mg} / \mathrm{L}$, whereas the total nitrogen (TN) concentration averaged $6.39 \mathrm{mg} / \mathrm{L}$ (Squillace and Engberg, 1988). The maximum dissolved nitrate was less than $10.0 \mathrm{mg} / \mathrm{L}$ (Squillace and Engberg, 1988). There was little variability in the average and maximum nitrate concentrations from the most upstream site at Floyd (about 100 miles north of Cedar Rapids) to about 7 miles downstream from Cedar Rapids at Bertram, Iowa (fig. 2). In the early 1990s, the average dissolved nitrate concentration at a site on the Cedar River downstream from Cedar Rapids was $9.0 \mathrm{mg} / \mathrm{L}$. Nitrate concentrations exceeded $10.0 \mathrm{mg} / \mathrm{L}$ in almost one-half of the 292 samples collected from August 1989 to July 1991 (Schulmeyer and others, 1995). The Cedar River was documented to be impaired for a segment of the river extending from its confluence with Bear Creek near the city of Palo, Iowa, to where McLoud Run enters the river at Cedar Rapids and was subsequently included on Iowa's 303(d) Impaired Waters Listing for the Cedar River for high nitrate concentrations in the drinking water supply for the City of Cedar Rapids (Iowa Department of Natural Resources, 2006).

During 1996-98, a tributary of the Shell Rock River; Flood Creek near Powersville, Iowa (not shown); Wolf Creek near Dysart, Iowa (site S13, fig. 3); and the Cedar River near

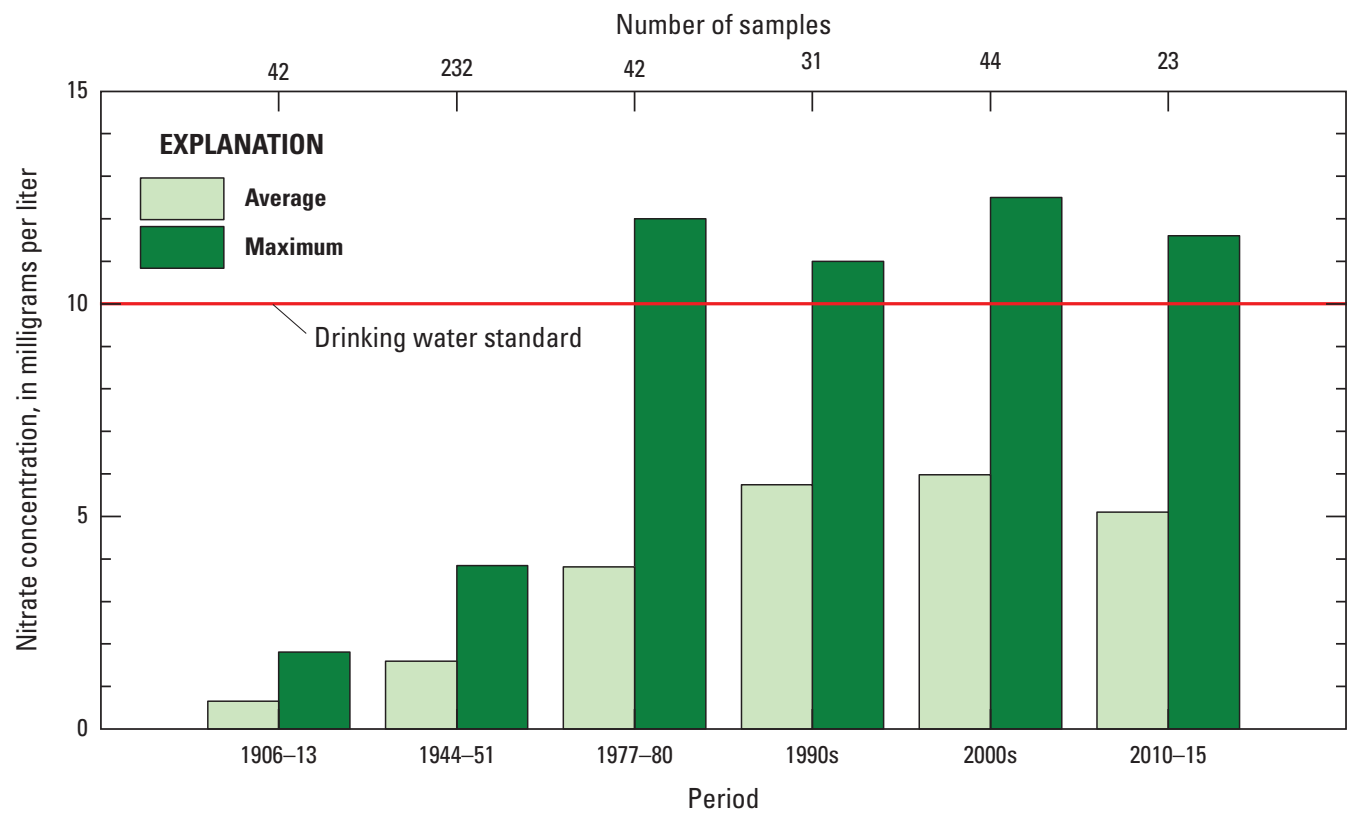

Figure 1. Historical nitrate concentrations in the Cedar River at Cedar Rapids, lowa. [Data from Dole, 1909; Clarke, 1924; Paulsen,1950, 1953; Love, 1956; U.S. Geological Survey, 1977, 1978, 1979, 1980; Littin and Schnoebelen, 2010; Littin, 2012; 1975-79 concentrations from Cedar River near Palo, lowa (U.S. Geological Survey site 05464450)] 
Conesville, Iowa (site 11, fig. 3), were sampled monthly as part of the U.S. Geological Survey (USGS) National WaterQuality Assessment Program (Becher and others, 2001). The median dissolved nitrate concentration in the Cedar River near the mouth (Conesville, Iowa) was $4.9 \mathrm{mg} / \mathrm{L}$ with a maximum concentration of $12.0 \mathrm{mg} / \mathrm{L}$ (Becher and others, 2001). The median TN concentration was $5.5 \mathrm{mg} / \mathrm{L}$, the median orthophosphate as phosphorus (OP) concentration was $0.11 \mathrm{mg} / \mathrm{L}$, and the median total phosphorus (TP) concentration was $0.26 \mathrm{mg} / \mathrm{L}$. Based on these sample concentrations and continuous streamflow data, the Cedar River Basin was estimated to yield between 14.1 and 42.8 pounds per acre (lb/acre) of TN and between 0.69 and $1.07 \mathrm{lb} /$ acre of TP in 1996-98 (Becher and others, 2001).

In the headwaters of the Cedar and Shell Rock Rivers in Minnesota, there was a significant long-term (1960s-2009) increasing trend in nitrate concentrations, but during the 1995-2009 period, nitrate concentrations were significantly increasing in only the headwaters of the Cedar River (Christopherson, 2014). Nitrate plus nitrite concentrations increased annually at an average rate of 2.5 to 3.2 percent at two sites on the Cedar River from 1967 to 2009 and 4.6 percent at one site on the Shell Rock River from 1961 to 2009. There was a consistent increasing nitrate trend through the period in the Cedar River south of Austin, Minnesota, but no significant trend during the latter part of the study period in the Cedar River east of Lansing, Minn. (about 5 miles north of Austin, Minn.), and in the Shell Rock River west of Gordonsville, Minn., near the Iowa-Minnesota State line (Christopherson, 2014).
Phosphorus data from the Cedar River Basin is more limited than nitrogen data. The average OP concentration in monthly samples collected at five main-stem sites on the Cedar River during 1984-85 was $0.14 \mathrm{mg} / \mathrm{L}$ and the average TP concentration was $0.21 \mathrm{mg} / \mathrm{L}$ (Squillace and Engberg, 1988). The maximum concentrations of OP and TP were similar $(0.46 \mathrm{mg} / \mathrm{L}$ and $0.48 \mathrm{mg} / \mathrm{L})$.

In Minnesota, there was a significant decreasing trend in TP concentrations in the Cedar and Shell Rock Rivers in Minnesota (Christopherson, 2014) from the 1960s to 2009. TP decreased at an average annual rate of 1.0 to 2.9 percent. TP concentrations did not change significantly from 1995 to 2009 (Christopherson, 2014).

\section{Purpose and Scope}

The purpose of this report is to document the current (2000-15) transport of nitrogen and phosphorus from the Cedar River Basin to the Iowa River and to document spatial differences in the origin of nitrogen and phosphorus in the Cedar River Basin in Iowa and Minnesota. A secondary objective is to determine if the transport of these nutrients has changed during 2000-15.

Data used for this analysis were collected by the USGS during this study and from stream and river monitoring data collected by the Minnesota Pollution Control Agency (MPCA) and the Iowa Department of Natural Resources (IADNR). Nutrient transport was evaluated in relation to runoff to

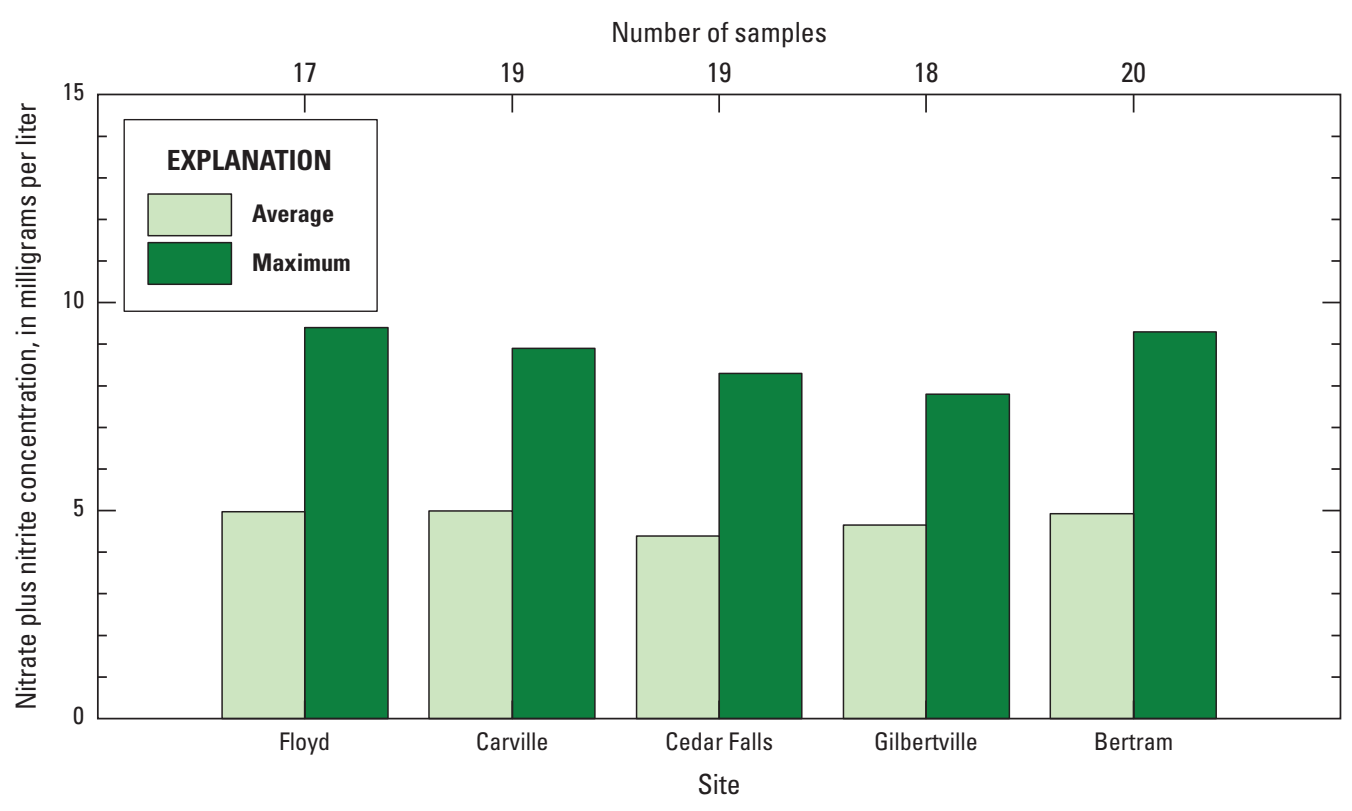

Figure 2. Nitrate plus nitrite nitrogen concentrations in the Cedar River at five main-stem sites, 1984-85. [Data from Squillace and Engberg, 1988] 
understand how streamflow affects transport. Spatial differences and trends in nutrients in the Cedar River Basin are discussed in relation to dissolved and total nitrogen and phosphorus species. Total nitrogen is the sum of nitrate and total Kjeldahl nitrogen. Nitrate is reported as nitrogen in this report. Total phosphorus is an analytically determined concentration. Spatial differences in the source areas of nitrogen and phosphorus were documented using calculated annual nitrogen and phosphorus yields. The scope of this report does not include investigating the causes for spatial difference in transport.

\section{Description of the Cedar River Basin}

The Cedar River originates in southern Minnesota and then flows more than 300 miles south through eastern Iowa draining approximately 7,800 square miles $\left(\mathrm{mi}^{2}\right)$ before joining the Iowa River. The Cedar River Basin commonly is divided into the Upper, Middle, and Lower Cedar River Basins with distinct differences in the physical character and hydrology.

The Upper Cedar River Basin is 4,340 $\mathrm{mi}^{2}$ and includes the Shell Rock, Winnebago, Little Cedar, and West Fork Cedar Rivers and the Cedar River from the headwaters in southern Minnesota to the confluence with the Shell Rock and West Fork Cedar Rivers north of Cedar Falls, Iowa (fig. 3). Four eight-digit hydrologic units (table 1) make up the Upper Cedar River Basin. The Middle Cedar River Basin extends from an area drained by the Cedar River upstream from Cedar Falls, Iowa, to the confluence with Prairie Creek downstream from Cedar Rapids, Iowa, and encompasses 2,410 $\mathrm{mi}^{2}$. Prairie, Beaver, Black Hawk, and Wolf Creeks are the major tributaries to the Cedar River in the Middle Cedar River Basin. The Lower Cedar River Basin is the smallest section of the Cedar River Basin and is 1,060 $\mathrm{mi}^{2}$ in area. The Lower Cedar River Basin encompasses the area drained by the Cedar River downstream from Cedar Rapids to the confluence with the Iowa River. Rock and Sugar Creeks are two larger Cedar River tributaries in the basin.

\section{Climate}

The long-term (1981-2010) average precipitation of the five climatic regions that contain the Cedar River Basin was 34.74 inches (in.) (fig. 4). Annual average rainfall in the Cedar River Basin was variable during the 2000-15 study and ranged from about $10 \mathrm{in}$. below normal in 2012 to about $7 \mathrm{in}$. above normal in 2010, but the annual average for this period was close to the long-term (1981-2010) average. Average annual rainfall during the first part (2000-6) of the study (32.52 in.) was below the long-term average for all years except 2004 when rainfall was slightly greater than the long-term average. In contrast, average annual rainfall during the second part (2007-15) of the study (37.18 in.) was greater than the longterm average for all years but 2011 and 2012. Annual average rainfall in 2012 was near a record low for Iowa and southern Minnesota.

\section{Topography and Geology}

The land surface in the Cedar River Basin ranges from flat to rolling. The land surface in the western and northwestern edges of the basin, the Des Moines Lobe landform (Prior, 1991), extends from Steele County in Minnesota to northeastern Hardin County in Iowa. The Des Moines Lobe is in the headwaters of the Shell Rock River in Minnesota and Iowa and the western part of the Cedar River Basin in Minnesota. The land surface is relatively flat and poorly drained (Prior, 1991) and has remnant prairie potholes that are now mostly drained by subsurface drain tiles.

Except for the Lower part, most of the remainder of the Cedar River Basin is in the Iowan Surface landform (Prior, 1991), which has a slightly to gently rolling land surface with a well-established drainage network. Thin layers of windblown loess cover drift deposits. Bedrock is near the surface in the northern part of the basin.

The Lower part of the Cedar River Basin downstream from Cedar Rapids, Iowa, is in the Southern Iowa Drift Plain landform region (Prior, 1991). The Southern Iowa Drift Plain is characterized by a broad flat drainage divide that covers much of the Lower Cedar River Basin downstream from Cedar Rapids, Iowa. Variable thickness of windblown loess covers glacial till, which is drained by a well-defined network of streams and rivers.

An extensive flood plain borders the Cedar River in Muscatine County that is part of the Mississippi Alluvial Plain. The lower reach of the Cedar River flows through the Mississippi Alluvial Plain in Muscatine County before it joins the Iowa River. The Mississippi Alluvial Plain contains numerous oxbow ponds and sand and clay deposits that reflect the effects of flowing water (Prior, 1991).

\section{Land Use}

Abundant rainfall combined with relatively flat land surface having rich soils, which formed on the loess and drift deposits, provide an ideal environment for the growth of row crops in the Cedar River Basin. More than 80 percent of the basin is used for agricultural purposes, mostly for corn and soybean production with some pasture land, hay, and small grains (Iowa Department of Natural Resources, 2006). The 2010 population of incorporated cities and towns in the Cedar River Basin was about 515,000 (U.S. Census Bureau, 2010). The major cities with populations greater than 10,000 include Austin and Albert Lea in Minnesota and Mason City, Cedar Falls, Waterloo, Marion, and Cedar Rapids in Iowa (fig. 3).

\section{Hydrology}

The annual mean discharge from the Cedar River (fig. 5) was highly variable from 2000 to 2015 and reflected the pattern of rainfall in eastern Iowa and southern Minnesota. The annual mean stream discharge from the Cedar River 


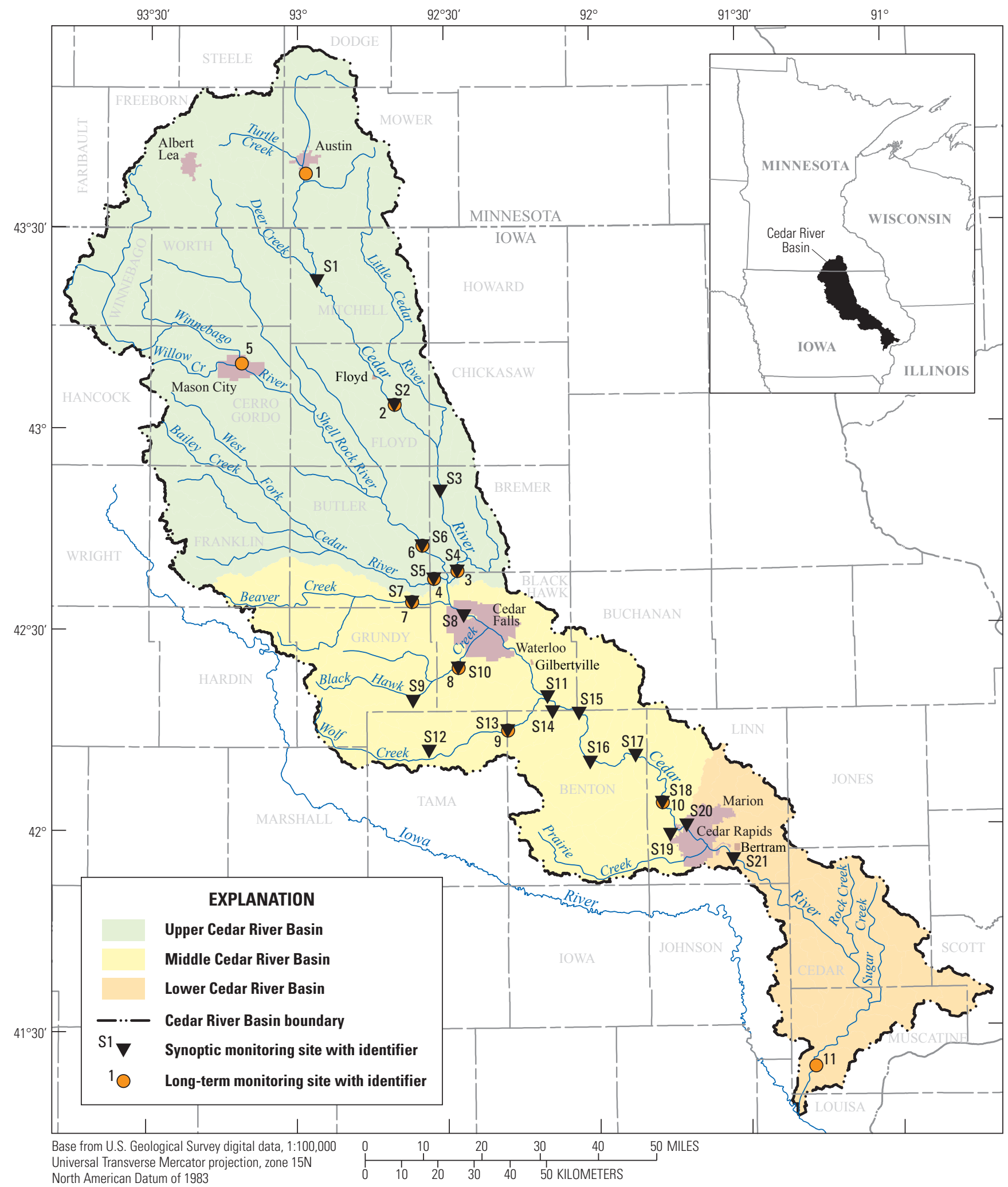

Figure 3. The Cedar River Basin in lowa and Minnesota showing the Upper, Middle, and Lower Cedar River Basins and the locations of synoptic and long-term monitoring sites. 
Table 1. Description of the Cedar River Basin in lowa and Minnesota.

[HUC, hydrologic unit code; $\mathrm{mi}^{2}$, square mile. Hydrologic units from Seaber and others, 1987]

\begin{tabular}{cclr}
\hline Basin & HUC & \multicolumn{1}{c}{ Description } & \multicolumn{1}{c}{$\begin{array}{c}\text { Area } \\
\left(\mathbf{m i} \mathbf{2}^{\mathbf{}}\right)\end{array}$} \\
\hline Upper Cedar River & 07080201 & Upper Cedar River & 1,730 \\
& 07080202 & Shell Rock River & 1,060 \\
& 07080203 & Winnebago River & 704 \\
& 07080204 & West Fork Cedar River & 850 \\
Middle Cedar River & 07080205 & Middle Cedar River & 2,410 \\
Lower Cedar River & 07080206 & Lower Cedar River & 1,060 \\
\hline
\end{tabular}

Basin (fig. 5) ranged from 2,590 cubic feet per second $\left(\mathrm{ft}^{3} / \mathrm{s}\right)$ in 2012 to $14,100 \mathrm{ft}^{3} / \mathrm{s}$ in 2008 . The annual mean discharge corresponds to runoff (the depth to which the basin would be covered if annual discharge were distributed on it uniformly) from 4.53 in. in 2012 to 24.6 in. in 2008 . Annual mean stream discharge in 2012 was the 10th smallest since continuous discharge measurements began in 1940. In contrast, annual mean discharge in 2008 and 2010 were the second and third largest on record, respectively. Generally, stream discharge was at or below the long-term average during the first part of the study and generally was greater than the long-term average during the second part of the study (fig. 5). Because of the wide range, discharge during the study period was representative of extremely dry to extremely wet flow conditions in the Cedar River Basin.
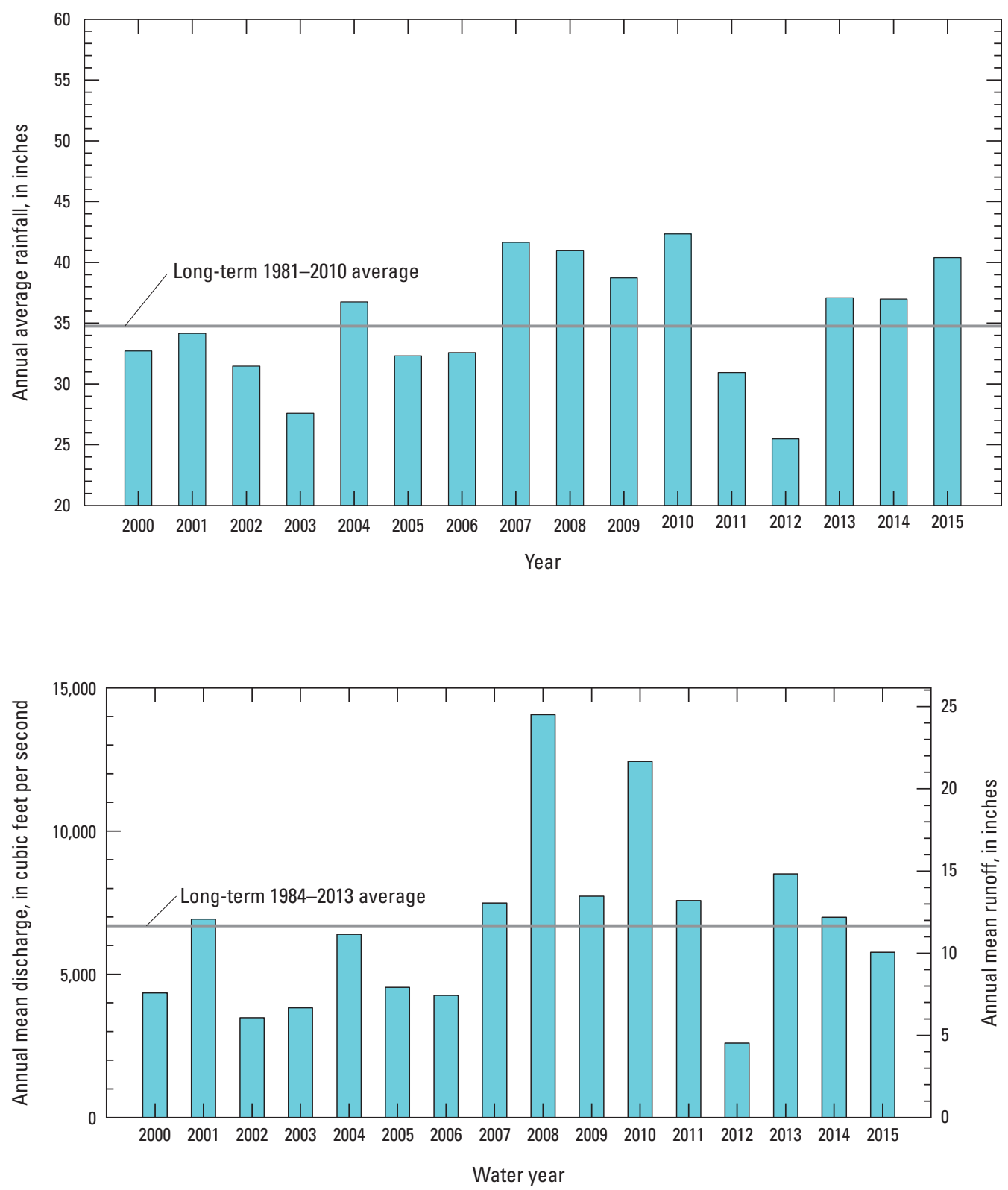

Figure 4. Annual average rainfall in the Cedar River Basin, lowa and Minnesota, 2000-15. [Annual average rainfall is the average from lowa climatic regions 2 , 3,5 , and 6 and Minnesota climatic region 8 (Midwestern Regional Climate Center, 2015)]
Figure 5. Annual mean discharge and runoff from the Cedar River Basin. [Measured in the Cedar River near Conesville, lowa; U.S. Geological Survey site 05465000 , from U.S. Geological Survey (2017); long-term average discharge from Eash and others (2015)] 


\section{Data Collection and Analysis}

Data to quantify contributing areas for nitrogen and phosphorus in the Cedar River Basin were obtained by completing short-term synoptic studies during stable, base-flow conditions and from long-term monitoring completed by the IADNR, the MPCA, and the USGS.

\section{Synoptic Studies}

Short-term synoptic studies were designed to measure nutrient concentrations and to quantify nutrient transport during periods when most of the water in the Cedar River and its tributaries originated from groundwater (including tile-line discharge) and point-source discharges. Synoptic studies were completed in the spring and fall from 2000 to 2002 to document base-flow conditions and again a decade later in 2010-12 to document water-quality changes over time.

\section{Timing of Sample Collection}

Synoptic studies were scheduled during stable base-flow conditions generally after an extended period without rain. Samples were collected over several days with stable flow that ensured all samples were collected under the same flow conditions and that results were not affected by rainfall runoff. Because base flow is not consistent throughout the year, low base-flow that generally is in the fall and high base flow that generally is in the spring were sampled.

Low base-flow synoptic studies were completed in the fall (September or October) when lesser amounts of rainfall generate relatively low base-flow conditions (Eash and others, 2015). Dry late summer and early fall conditions limit the infiltration of water to the water table and shallow alluvial aquifers, resulting in less inflow from tile-line discharge and groundwater. Samples also were collected in spring (May) after snowmelt and spring rains have recharged the shallow alluvial aquifers typically resulting in high base-flow conditions.
The initial low and high base-flow synoptic study was completed in November 2000 and May 2001. A followup study was completed in September 2002 after a drier than normal summer (table 2). The second set of synoptic samples was collected a decade later in October 2010 and May 2011 to evaluate changes in nutrient concentrations and source areas. As with the initial synoptic studies in the early 2000s, a followup study (September 2012) was completed after below normal rainfall and discharge in the Cedar River Basin (figs. 4 and 5) in 2012.

Unlike the previous synoptic sampling studies, the flow conditions were not stable during the May 2001 synoptic study. Rain fell in the Cedar River Basin during the week of May 21-25, 2001 (Midwestern Regional Climate Center, 2015 ) while the samples were being collected. Additional rain fell during the weekend of May 26-27, 2001 (Midwestern Regional Climate Center, 2015), before sampling recommenced on May 29, 2001. This rain resulted in a substantial increase in streamflow between May 25 and May 29. Samples collected on May 29-31, 2001, probably were not representative of stable base-flow conditions and are not directly comparable to those collected the previous week.

\section{Selection of Sampling Sites}

A total of 21 sites in the Upper and Middle Cedar River Basins were selected for sampling as part of the synoptic studies (fig. 3, table 3). A total of 12 sampling sites were selected on the main stem of the Cedar River from St. Ansgar in northern Iowa downstream to the Highway 30 Bridge near Bertram, Iowa, to document variability in nutrient concentrations and loads. Sampling sites on nine Cedar River tributaries were selected to quantify the amount and location of nutrient transported to the Cedar River. Data collection in the Upper Cedar River Basin primarily was focused on the main stem (four sites) and two major tributaries, the Shell Rock and West Fork Cedar Rivers (fig. 3). All but 1 of the remaining sampling sites were in the Middle Cedar River Basin; 7 sites on the main stem and 7 sites on tributaries. The most downstream

Table 2. Flow conditions in the Cedar River Basin during base-flow synoptic sampling studies.

[Monthly mean discharge data from U.S. Geological Survey, 2017]

\begin{tabular}{llcc}
\hline Sample month & Season & $\begin{array}{r}\text { Percentage of monthly mean discharge in the sample month in relation } \\
\text { to mean monthly discharge for study period, 2000-15 }\end{array}$ \\
\cline { 3 - 4 } & & $\begin{array}{r}\text { Cedar River at Charles City, lowa } \\
\text { Cedar River at Cedar Rapids, lowa }\end{array}$ \\
\hline September 2002 & Dry fall & 31 & 64 \\
September 2012 & Dry fall & 19 & 21 \\
November 2000 & Fall & 95 & 63 \\
October 2010 & Fall & 143 & 162 \\
May 2001 & Spring & 162 & 144 \\
May 2011 & Spring & 104 & 108 \\
\hline
\end{tabular}


synoptic site was on the Cedar River near Bertram (fig. 3) in the Lower Cedar River Basin. The drainage area (subbasin) contributing water and nutrients to the synoptic sampling sites (table 3) ranged from $17 \mathrm{mi}^{2}$ on Morgan Creek (site S19) to $1,746 \mathrm{mi}^{2}$ on the Shell Rock River (site S6).

\section{Data Collection Methods}

Data needed to quantify nutrient transport during baseflow conditions include stream discharge and concentrations of dissolved nitrate, total ammonia plus organic nitrogen as nitrogen (TKN), dissolved orthophosphate (OP), and TP.
Stream discharge measurements were made at the time of sample collection using the midsection method (Turnipseed and Sauer, 2010) with an Acoustic Doppler Velocity meter (ADVM) for wading measurements and a cable-mounted Acoustic Doppler Current Profiler (ADCP) for main-stem sites where wading was not possible. Streamflow from several sites was not measured directly but was obtained from permanent USGS streamgages at the sampling site or was estimated using the flow duration curve transfer method (Linhart and others, 2012). Data are available from the USGS National Water Information System (U.S. Geological Survey, 2017).

Nutrient data were obtained from the analysis of representative discrete water samples collected at each site.

Table 3. Synoptic monitoring sites in the Cedar River Basin.

[USGS, U.S. Geological Survey; mi², square mile; IA, Iowa; Hwy, Highway]

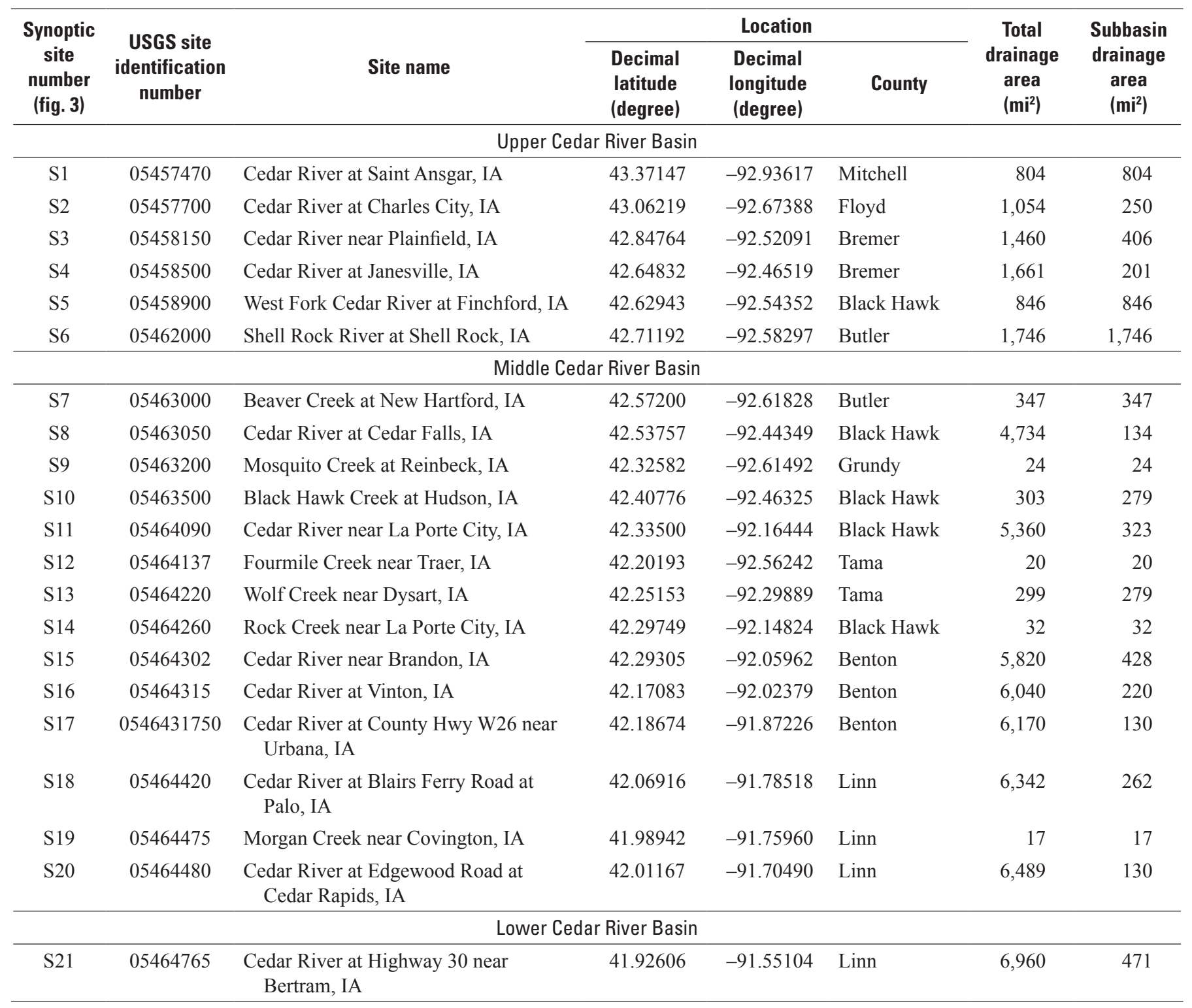


Individual stream samples were a composite of depth integrated samples from a minimum of 10 equal width verticals across the stream (U.S. Geological Survey, 2006). Water samples from each vertical were collected with a hand-held or cable mounted isokinetic depth-integrating sampler (U.S. Geological Survey, variously dated) and were composited into a Teflon churn for mixing. Water analyzed for TP and TKN concentrations was poured directly from the churn into a polyethylene bottle. Water analyzed for nitrate and OP was pumped from the churn through a polyethersulfone capsule filter with a nominal 0.45 -micrometer pore size into a brown polyethylene bottle (Wilde and others, 2004). The unfiltered sample was preserved by acidifying to a $\mathrm{pH}$ less than 2.0 with $4.5 \mathrm{~N}$ sulfuric acid. The filtered and unfiltered samples were chilled and shipped on ice overnight to the USGS National Water Quality Laboratory in Denver, Colorado. Samples were analyzed for nitrate (Patton and Kryskalla, 2011) and OP and TP (Fishman, 1993) using colorimetric methods. Samples were analyzed for TKN by a Kjeldahl digestion (Patton and Truitt, 2000). Data are available from the USGS National Water Information System (U.S. Geological Survey, 2017).

Sampling equipment that included samplers, sample churns, and tubing was cleaned before each sample to prevent cross contamination. Detailed cleaning instructions are provided in Wilde (2004) and are summarized here. The sampling equipment was soaked in a nonphosphate detergent solution and scrubbed, if needed, to remove any adhering material. The equipment was rinsed, first with tap water and then with deionized water, to remove any remaining detergent. If not immediately needed, the sampling equipment was air dried and then stored in sealed plastic bags.

\section{Long-Term Monitoring Data}

Synoptic studies provided a detailed "snapshot" of waterquality conditions and nutrient source areas in the Cedar River Basin during six periods of stable base flow from 2000 to 2012, but additional comprehensive temporal data are needed to define the transport of nitrogen and phosphorus from 2000 through 2015. Temporal water-quality data from 11 sites (fig. 3, table 4) were obtained from monitoring programs led by the IADNR (10 sites), the MPCA ( 1 site), and the USGS (same as IADNR site 10 until October 2012). Data were from various periods (appendix 1) but generally covered the study period. Daily streamflow data (U.S. Geological Survey, 2017) used to calculate loads and yields were from USGS streamgages at or near the long-term monitoring sites. Discharge at seven of the sampling sites was estimated by using the drainage area ratio method (Hirsch, 1979) with nearby streamflow-gaging stations (appendix 1).

\section{lowa Department of Natural Resources Monitoring}

Nitrate loads from 1999 through 2015 at 10 IADNR monitoring sites (fig. 3, appendix 1) in the Cedar River Basin were provided by Calvin Wolter (Iowa Department of Natural Resources, written commun., April 2016). Analytical data for TKN, OP, and TP at the 10 IADNR sites were downloaded from the Iowa AQuIA Water Quality database (https://programs.iowadnr.gov/aquia/).

The IADNR long-term water-quality monitoring sites used in this study are mainly in the Upper and Middle Cedar River Basins (table 4). Two IADNR Upper Cedar River Basin sites are on the main stem of the Cedar River near Charles City and at Janesville, Iowa. Two sites are near the mouth of three major tributaries to the Cedar River. Two of these sites are on the West Fork Cedar River at Finchford, Iowa, and the Shell Rock River upstream from Shell Rock, Iowa. Another site, Winnebago River upstream from Mason City, Iowa, is nested in the Shell Rock Basin. Three sites on tributaries and one on the Cedar River are in the Middle Cedar River Basin. The tributary sites are on Beaver Creek near Cedar Falls, Black Hawk Creek at Waterloo, and Wolf Creek at La Porte City. The site on the main stem of the Cedar River upstream from Cedar Rapids, Iowa, is near the outlet of the Middle Cedar River Basin. The most downstream site, Cedar River near Conesville, Iowa, is near the mouth of the Cedar River in the Lower Cedar River Basin.

IADNR samples were collected monthly by the University of Iowa State Hygienic Laboratory (SHL) Limnology Section personnel. The standard operating procedures used by the SHL to sample rivers and streams were provided by Michael Schueller (SHL, written commun., January 26, 2017). Grab samples were collected by dipping a high-density polyethylene bucket into the midstream flowing well-mixed section of the river or stream. The sampling bucket was rinsed twice with river water from the sampling site before sample collection. Once collected, the sample then was split into appropriate containers for analysis of nutrients and other water-quality constituents. Samples were stored on ice until transported to the laboratory. Split and blank samples are collected on 10 to 15 percent of all samples to ensure data accuracy.

Samples were analyzed by the SHL using U.S. Environmental Protection Agency (EPA) analytical methods (Michael Schueller, University of Iowa State Hygienic Laboratory, written commun., January 26, 2017). Laboratory analysis of an unfiltered sample for nitrate plus nitrite nitrogen concentrations was by EPA method 353.2 (O’Dell, 1993b), total Kjeldahl nitrogen was by EPA method 351.2 (O'Dell, 1993a), and TP was by EPA method 365.4 (U.S. Environmental Protection Agency, 1974). A filtered sample was analyzed for orthophosphate by EPA method 365.1 (O'Dell, 1993c). 
Table 4. Long-term monitoring sites in the Cedar River Basin, lowa and Minnesota, 2000-15.

[STORET, U.S. Environmental Protection Agency Storage and Retrieval System; mi², square mile; MPCA, Minnesota Pollution Control Agency; MN, Minnesota; IADNR, Iowa Department of Natural Resources; IA, Iowa]

\begin{tabular}{|c|c|c|c|c|c|c|c|}
\hline $\begin{array}{l}\text { Map number } \\
\text { (fig. 3) }\end{array}$ & $\begin{array}{c}\text { STORET } \\
\text { identification } \\
\text { number }\end{array}$ & $\begin{array}{l}\text { Monitoring } \\
\text { agency }\end{array}$ & Station name & $\begin{array}{l}\text { Decimal } \\
\text { latitude } \\
\text { (degree) }\end{array}$ & $\begin{array}{c}\text { Decimal } \\
\text { longitude } \\
\text { (degree) }\end{array}$ & County & $\begin{array}{l}\text { Drainage area } \\
\qquad\left(\mathrm{mi}^{2}\right)\end{array}$ \\
\hline \multicolumn{8}{|c|}{ Upper Cedar River Basin } \\
\hline 1 & S000-001* & MPCA & $\begin{array}{l}\text { Cedar River near } \\
\text { Austin, MN }\end{array}$ & 43.637185 & -92.974637 & Mower & 399 \\
\hline 2 & 10340001 & IADNR & $\begin{array}{l}\text { Cedar River near Charles } \\
\text { City, IA }\end{array}$ & 43.062195 & -92.673884 & Floyd & 1,054 \\
\hline 3 & 10090001 & IADNR & $\begin{array}{l}\text { Cedar River at } \\
\text { Janesville, IA }\end{array}$ & 42.648316 & -92.465186 & Bremer & 1,661 \\
\hline 4 & 10070003 & IADNR & $\begin{array}{l}\text { West Fork Cedar River } \\
\text { at Finchford, IA }\end{array}$ & 42.629426 & -92.543522 & Black Hawk & 846 \\
\hline 5 & 10170002 & IADNR & $\begin{array}{l}\text { Winnebago River } \\
\text { upstream of Mason } \\
\text { City, IA }\end{array}$ & 43.192887 & -93.210464 & Cerro Gordo & 454 \\
\hline \multicolumn{8}{|c|}{ Middle Cedar River Basin } \\
\hline 7 & 10070001 & IADNR & $\begin{array}{l}\text { Beaver Creek near Cedar } \\
\text { Falls, IA }\end{array}$ & 42.573170 & -92.506701 & Butler & 347 \\
\hline 8 & 10070004 & IADNR & $\begin{array}{l}\text { Black Hawk Creek at } \\
\text { Waterloo, IA }\end{array}$ & 42.442995 & -92.431825 & Black Hawk & 326 \\
\hline 9 & 10070006 & IADNR & $\begin{array}{l}\text { Wolf Creek at La Porte } \\
\text { City, IA }\end{array}$ & 42.315824 & -92.193794 & Tama & 327 \\
\hline 10 & 10570002 & IADNR & $\begin{array}{l}\text { Cedar River upstream of } \\
\text { Cedar Rapids, IA }\end{array}$ & 42.069163 & -91.785180 & Linn & 6,342 \\
\hline
\end{tabular}

*MPCA site identification number.

\section{Minnesota Pollution Control Agency}

Water-quality data from the Cedar River near Austin, Minn., were collected as part of the MPCA Watershed Pollutant Load Monitoring Network and were used to quantify nutrient transport from the Minnesota section of the Cedar River Basin. Sampling for the Watershed Pollutant Load Monitoring Network began in 2007. About 35 samples were collected annually with emphasis placed on intensive sampling of major rain events (Minnesota Pollution Control Agency, 2015). Detailed sampling procedures are described in the MPCA's standard operating procedures and guidance for the Watershed Pollutant Load Monitoring Network (Minnesota Pollution Control Agency, 2015). Briefly, all sampling equipment was rinsed with distilled water before sample collection. Samples were collected about 1 foot below the surface in the deepest part of the stream with a weighted bucket, with a Van Dorn sampler, or by filling the sample bottle directly. Samples were collected for the analysis of nitrate, TKN, OP, and TP. Sulfuric acid was added to preserve the TP, nitrate, and TKN samples. All samples were shipped on ice to the laboratory. OP samples generally were collected unfiltered from March 2007 until May 2013. OP samples collected after May 4, 2013, were filtered before analysis.

Laboratory analysis of nitrate plus nitrite nitrogen concentrations was by EPA method 353.2 (O'Dell, 1993b); TKN was by EPA method 351.2 (O'Dell, 1993a); and OP and TP were by EPA method 365.1 (O’Dell, 1993c). Water-quality data were downloaded from the Minnesota Department of Natural Resources/MPCA Cooperative Stream Gaging web page (https://cf.pca.state.mn.us/eda/stationInfo.php?ID=S000001\&ORG=MNPCA\&wdip=2). Only MPCA data collected from 2007 to 2015 were used for this report. The MPCA uses the analytical results with daily streamflow to estimate nutrient loads using the "Flux32" load estimation program (Minnesota Pollution Control Agency, 2012). 


\section{U.S. Geological Survey Continuous Nitrate Monitoring}

Nitrate concentrations in the Cedar River near the outlet of the Middle Cedar River Basin have been measured at 15-minute intervals during the ice-free season (March or April through November) using an instream optical nitrate sensor since 2009. The nitrate sensor $\left(\operatorname{Hach}^{\circledR}\right.$ NITRATAX plus sc) initially was installed at the Cedar River at Cedar Rapids, Iowa, USGS gaging station (05464500). The sensor was operated at this site until October 2012, when it was moved upstream about 14 miles to the Cedar River at Blairs Ferry Road at Palo, Iowa, USGS gaging station (05464420).

The sensor uses the absorbance of ultraviolet light by nitrate, which is measured by a photometer and is converted to a nitrate concentration (Pellerin and others, 2013). Nitrate concentrations are recorded at 15-minute intervals, which then are used to calculate daily mean nitrate concentrations. Field maintenance for the nitrate sensor includes site inspection, instrument inspection and cleaning, field-blank or calibration checks, and discrete sample collection (Pellerin and others, 2013). Field maintenance was scheduled on 6-week intervals or more frequently if needed. The daily mean nitrate concentrations were downloaded from the USGS National Water Information System database (U.S. Geological Survey, 2017).

\section{Long-Term Monitoring Subbasins}

Water sampled at the 11 long-term monitoring sites is a composite of water entering the river upstream from the sampling site. This water includes overland flow; groundwater inflow, direct and from subsurface drainage; and municipal discharge. The quality of water sampled is representative of the water entering the river upstream from the sampling site. If another sampling site is farther upstream, the water and nutrient contributions from separate subbasins can be quantified. One subbasin would be the area draining to the river above the upstream sampling site and the second subbasin would be the area draining to the river below the upstream sampling site and above the downstream sampling site.

The 11 long-term monitoring sites resulted in 11 subbasins whose boundaries were delineated using the basin delineation function of the USGS Geographic Information System StreamStats program (Ries and others, 2008). The subbasins were named for descriptive purposes for this report. The longterm subbasins (fig. 6, table 5) are described briefly below.

Minnesota Cedar River.-This subbasin includes $399 \mathrm{mi}^{2}$ in Minnesota that drains to the Cedar River upstream from the sampling site near Austin, Minn. The Minnesota Cedar River subbasin includes the city of Austin, Minn. Several creeks are important tributaries to the Cedar River in the subbasin (Minnesota Pollution Control Agency, 2012).

Main Stem Upper Cedar River.-This subbasin includes $655 \mathrm{mi}^{2}$ in Minnesota and Iowa that drain to the Cedar River downstream from the sampling site near Austin, Minn., and upstream from the sampling site near Charles City, Iowa.
Little Cedar River.-This subbasin includes $607 \mathrm{mi}^{2}$ in Minnesota and Iowa that drain to the Little Cedar River and to the main stem of the Cedar River downstream from the sampling site near Charles City, Iowa, and upstream from the sampling site at Janesville, Iowa.

Upper Winnebago River.-This subbasin includes $526 \mathrm{mi}^{2}$ in Minnesota and Iowa that drain to the Winnebago River upstream from the sampling site upstream from Mason City, Iowa. The city of Albert Lea, Minn., is in the Upper Winnebago River subbasin.

Shell Rock River.-This subbasin includes $1,220 \mathrm{mi}^{2}$ that drain to the Shell Rock River (excluding the Upper Winnebago River subbasin) upstream from the sampling site at Shell Rock, Iowa. This subbasin includes Mason City, Iowa.

West Fork Cedar River.-This subbasin includes $846 \mathrm{mi}^{2}$ that drain to the West Fork Cedar River upstream from the sampling site at Finchford, Iowa.

Beaver Creek.-This subbasin includes $347 \mathrm{mi}^{2}$ that drain to Beaver Creek upstream from the sampling site near Cedar Falls, Iowa.

Black Hawk Creek.-This subbasin includes $326 \mathrm{mi}^{2}$ that drain to Black Hawk Creek upstream from the sampling site at Waterloo, Iowa.

Wolf Creek.-This subbasin includes $327 \mathrm{mi}^{2}$ that drain to Wolf Creek upstream from the sampling site at La Porte City, Iowa.

Main Stem Middle Cedar River.-This subbasin includes $614 \mathrm{mi}^{2}$ that drain to the main stem of the Cedar River downstream from the sampling site at Janesville, Iowa, and upstream from the sampling site upstream from Cedar Rapids, Iowa. The Main Stem Middle Cedar River subbasin does not include drainage from the Shell Rock River (Shell Rock River and Upper Winnebago River subbasins), the West Fork Cedar River subbasin, Beaver Creek subbasin, Black Hawk Creek subbasin, and Wolf Creek subbasin. The Main Stem Middle Cedar River includes the Cedar Falls/Waterloo metropolitan area.

Lower Cedar River.-This subbasin includes 1,445 $\mathrm{mi}^{2}$ that drain to the Cedar River downstream from the sampling site upstream from Cedar Rapids, Iowa, and upstream from the sampling site near Conesville, Iowa. The Lower Cedar River subbasin includes the Cedar Rapids/Marion metropolitan area.

\section{Calculation of Load and Yield}

A load is a mass of constituent transported past a given site for a defined unit of time and a yield is the load divided by contributing drainage area. The transport of nitrogen and phosphorus in rivers and streams in the Cedar River Basin was quantified by estimating the daily load and yield at the synoptic study sites and by estimating the annual load and yield at the long-term monitoring sites. Subbasin loads were calculated by subtracting the load estimated at the upstream site(s) (if any) from the load at the sampling site at the mouth of the subbasin. Subbasin yields, given in pounds per acre, were calculated by dividing the subbasin load, in pounds, by the 


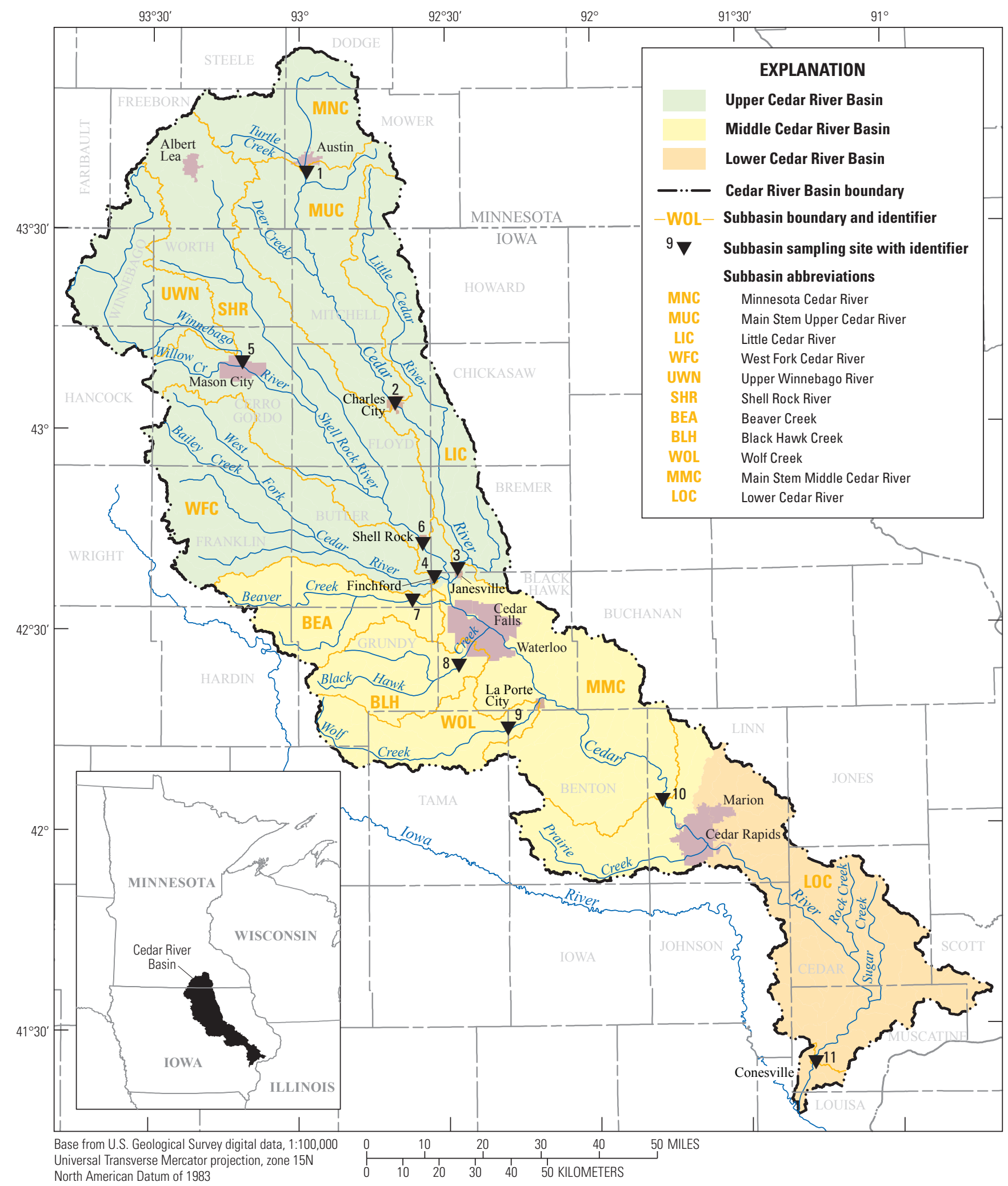

Figure 6. Long-term monitoring subbasins and their respective sampling sites in the Cedar River Basin, lowa and Minnesota. 
Table 5. Subbasins and their respective sampling sites in the Cedar River Basin, lowa and Minnesota.

$\left[\mathrm{mi}^{2}\right.$, square mile; MN, Minnesota; IA, Iowa $]$

\begin{tabular}{clcr}
\hline $\begin{array}{c}\text { Map identifier } \\
\text { (fig. 6) }\end{array}$ & \multicolumn{1}{c}{ Subbasin name } & \multicolumn{1}{c}{ Subbasin sampling site name } & $\begin{array}{c}\text { Subbasin drainage } \\
\text { area (mi) }\end{array}$ \\
\hline MNC & Minnesota Cedar River & Upper Cedar River Basin & 399 \\
MUC & Main Stem Upper Cedar River & Cedar River near Austin, MN & 655 \\
LIC & Little Cedar River & Cedar River near Charles City, IA & 607 \\
WFC & West Fork Cedar River & West Fork Cedar River at Finchford, IA & 846 \\
UWN & Upper Winnebago River & Winnebago River upstream from Mason City, IA & 526 \\
SHR & Shell Rock River & Shell Rock River at Shell Rock, IA & 1,220 \\
\hline BEA & Beaver Creek & Middle Cedar River Basin & 347 \\
BLH & Black Hawk Creek & Beaver Creek near Cedar Falls, IA & 326 \\
WOL & Wolf Creek & Black Hawk Creek at Waterloo, IA & 327 \\
MMC & Main Stem Middle Cedar River & Cedar River upstream from Cedar Rapids, IA & 614 \\
\hline & & Lower Cedar River Basin \\
\hline LOC & Lower Cedar River & Cedar River near Conesville, IA \\
\hline
\end{tabular}

difference in drainage area, in acres, between the sampling site and the drainage area at the next upstream sampling site(s).

\section{Synoptic Loads and Yields}

Water-quality and streamflow data were collected for each synoptic study in 2 or 3 days, and thus nutrient loads are reported in terms of pounds per day and nutrient yields in terms of pounds per day per square mile. Because flow conditions generally were stable during each synoptic study, the stream discharge measured at the time of sample collection and the concentration of each nitrogen and phosphorus species were assumed to be constant during the synoptic study. Daily loads and yields were estimated by multiplying the stream discharge by the concentration and by the appropriate conversion factor to obtain daily load values in pounds per day. The daily load then was divided by the drainage area in square miles to obtain the daily yield in pounds per day per square mile.

\section{Long-Term Load and Yield}

Nitrate, TN, OP, and TP loads were calculated at each long-term monitoring site on an annual basis to quantify the amount transported from each subbasin. Annual nutrient loads were calculated in tons per year. Annual nitrate, TN, OP, and TP yields were used to directly compare transport from subbasins irrespective of their drainage areas. Nutrient yields were calculated in pounds per acre per year.

Annual nutrient loads and yields were estimated for 11 subbasins within the Cedar River Basin and were based on data collected at the long-term monitoring sites. The drainage areas for the 11 subbasins are given in table 5. Annual nitrogen and phosphorus have been estimated using a number of methods (Lee and others, 2016), which at times have produced conflicting results (Schilling and others, 2017a). Load estimation techniques used for this report were those selected by the IADNR to estimate statewide nitrate loads and those identified by Lee and others (2016) that provide greater accuracy and lower bias for estimating TP loads.

Daily nitrate, TN, OP, and TP loads at each long-term monitoring site were calculated from the daily constituent concentration and daily mean discharge. The daily mean discharge was obtained from a USGS streamgage at or near the long-term monitoring site. The drainage area ratio method (Hirsch, 1979) is used by the IADNR to adjust streamflow at sites where the streamgage is not collocated at the sampling site because it is assumed that flow at the USGS streamgage in relation to the sampling site is equal to the ratio of the drainage area at the streamgage and sampling site. For consistency, the drainage area ratio method is used for this report. Drainage area ratios for each long-term site are listed in appendix 1.

Daily nitrate concentrations in the Cedar River upstream from Cedar Rapids were from the continuous nitrate measurements made at Cedar Rapids (2009-12) and from the Cedar River at Blairs Ferry Road at Palo (2012-15). Because of the short distance between these two sites (about 14.0 miles), nitrate concentrations measured in the Cedar River at Cedar Rapids were assumed to represent those measured upstream in the Cedar River at Palo. Missing data were filled using the IADNR data from Cedar River above Cedar Rapids and linear interpolation. Daily concentrations upstream from Cedar Rapids were estimated generally during late fall, winter, and 
early spring when the nitrate sensor was not deployed. Linear interpolation was used to estimate daily nitrate concentrations from monthly IADNR samples collected from the Cedar River above Cedar Rapids.

Daily nitrate loads were provided by the IADNR (Calvin Wolter, written commun., 2016). Daily TN, OP, and TP concentrations were estimated based on periodic samples collected from the 11 long-term monitoring sites in the Cedar River Basin (table 4). TN concentrations were not analyzed directly in the laboratory but were calculated by summing the dissolved nitrate and total organic nitrogen as nitrogen plus ammonia nitrogen (TKN) loads. Concentrations of dissolved nitrate and OP were estimated on days between samples using the fillMissing linear interpolation function in the smwrBase package (Lorenz, 2015), part of the USGS R library. Linear interpolation methods were used for nitrate for consistency (Schilling and others, 2017b) with the IADNR load estimation procedures. Dissolved OP was assumed to be transported through the environment similar to dissolved nitrate, and thus linear interpolation was used to estimate daily OP concentrations. Few examples of estimating daily OP concentrations and loads were in the literature; however, Schilling and others (2017a) and Garrett (2012) used regression models (LOADEST) with daily streamflow as an independent variable to estimate OP loads.

The linear interpolation method provides less accurate estimates for nondissolved constituents such as TKN and TP (Lee and others, 2016). The Weighted Regressions on Time, Discharge, and Season (WRTDS) model accurately estimates TN and TP loads (Lee and others, 2016) for long-term datasets. Based on previous research, the WRTDS model was the first choice for estimating daily TN and TP concentrations. The WRTDS model was used in the "R" EGRET package (Hirsch and De Cicco, 2015). If the WRTDS model estimates produced a load bias greater than 10 percent, indicating that the WRTDS model produced a poor estimate of the actual concentration, an alternative " $\mathrm{R}$ " version of the LOADEST regression model (Runkel and others, 2004) then was used to estimate concentrations. Although the LOADEST can produce biased results (Hirsch, 2014), evaluation of the model bias statistic (table 6) indicated that for constituents at several sites, the LOADEST model that used only a streamflow factor produced estimates with a load bias of 10 percent or less. Unbiased load models for two constituents (TKN and TP)

Table 6. Methods used to estimate nitrogen and phosphorus loads at the long-term monitoring sites in the Cedar River Basin, $2000-15$.

[N, nitrogen; P, phosphorus; MN, Minnesota; LINT, linear interpolation; NA, not applicable; WRTDS, Weighted Regressions on Time, Discharge, and Season; IA, Iowa; LDEST(1), LOADEST model 1; none, load calculated directly from mean daily nitrate concentrations and streamflow]

\begin{tabular}{|c|c|c|c|c|c|c|c|c|c|}
\hline \multirow{3}{*}{$\begin{array}{l}\text { Long-term } \\
\text { monitoring } \\
\text { site number } \\
\text { (fig. } 3 \text { ) }\end{array}$} & \multirow{3}{*}{ Station name } & \multicolumn{8}{|c|}{ Load model } \\
\hline & & \multicolumn{2}{|c|}{ Nitrate-N } & \multicolumn{2}{|c|}{ Kjeldahl-N } & \multicolumn{2}{|c|}{ Ortho-P } & \multicolumn{2}{|c|}{ Total-P } \\
\hline & & Model & $\begin{array}{c}\text { Bias } \\
\text { statistic }\end{array}$ & Model & $\begin{array}{c}\text { Bias } \\
\text { statistic }\end{array}$ & Model & $\begin{array}{c}\text { Bias } \\
\text { statistic }\end{array}$ & Model & $\begin{array}{c}\text { Bias } \\
\text { statistic }\end{array}$ \\
\hline \multicolumn{10}{|c|}{ Upper Cedar River Basin } \\
\hline 1 & Cedar River near Austin, MN & LINT & NA & WRTDS & 0.065 & LINT & NA & WRTDS & 0.048 \\
\hline 3 & Cedar River at Janesville, IA & LINT & NA & WRTDS & 0.019 & LINT & NA & LDEST(1) & -8.38 \\
\hline 4 & $\begin{array}{l}\text { West Fork Cedar River at Finch- } \\
\text { ford, IA }\end{array}$ & LINT & NA & WRTDS & -0.002 & LINT & NA & WRTDS & -0.015 \\
\hline 5 & $\begin{array}{l}\text { Winnebago River upstream from } \\
\text { Mason City, IA }\end{array}$ & LINT & NA & WRTDS & -0.002 & LINT & NA & WRTDS & 0.000 \\
\hline 7 & $\begin{array}{l}\text { Beaver Creek near Cedar Falls, } \\
\text { IA }\end{array}$ & LINT & NA & WRTDS & 0.056 & LINT & NA & WRTDS & 0.022 \\
\hline 8 & $\begin{array}{l}\text { Black Hawk Creek at Waterloo, } \\
\text { IA }\end{array}$ & LINT & NA & $\operatorname{LDEST}(1)$ & 4.960 & LINT & NA & $\operatorname{LDEST}(1)$ & -3.95 \\
\hline 9 & Wolf Creek at La Porte City, IA & LINT & NA & $\operatorname{LDEST}(1)$ & -28.51 & LINT & NA & $\operatorname{LDEST}(1)$ & -11.49 \\
\hline 10 & $\begin{array}{l}\text { Cedar River upstream from } \\
\text { Cedar Rapids, IA }\end{array}$ & $\begin{array}{l}\text { LINT/ } \\
\text { none }\end{array}$ & NA & WRTDS & -0.022 & LINT & NA & WRTDS & 0.018 \\
\hline \multicolumn{10}{|c|}{ Lower Cedar River Basin } \\
\hline 11 & Cedar River near Conesville, IA & LINT & NA & WRTDS & -0.025 & LINT & NA & WRTDS & -0.227 \\
\hline
\end{tabular}


from the Wolf Creek site were difficult to obtain. The "best" model (table 6) substantially underestimated the actual TKN and TP load. Because TKN is a small part of the TN load, this load bias probably had little effect on the estimated TN load in Wolf Creek. The TP estimates from the LOADEST model are used in this report as the best estimates available for Wolf Creek; however, they should be used with care. Examples showing the observed daily load estimated with the WRTDS model in relation to the observed daily load at two selected sites are shown in figure 7. All nitrogen and phosphorus concentration data from the periodic samples were used to develop the load models.

\section{Calculation of Annual Subbasin Loads and Yields}

Nutrient loads and yields in each subbasin were estimated using methods described for the long-term monitoring sites. On nested Cedar River main-stem sites, annual nutrient loads in subbasins were determined by difference. The annual load transported from the Little Cedar River, Shell Rock River, Main Middle Cedar River, and Lower Cedar River subbasins
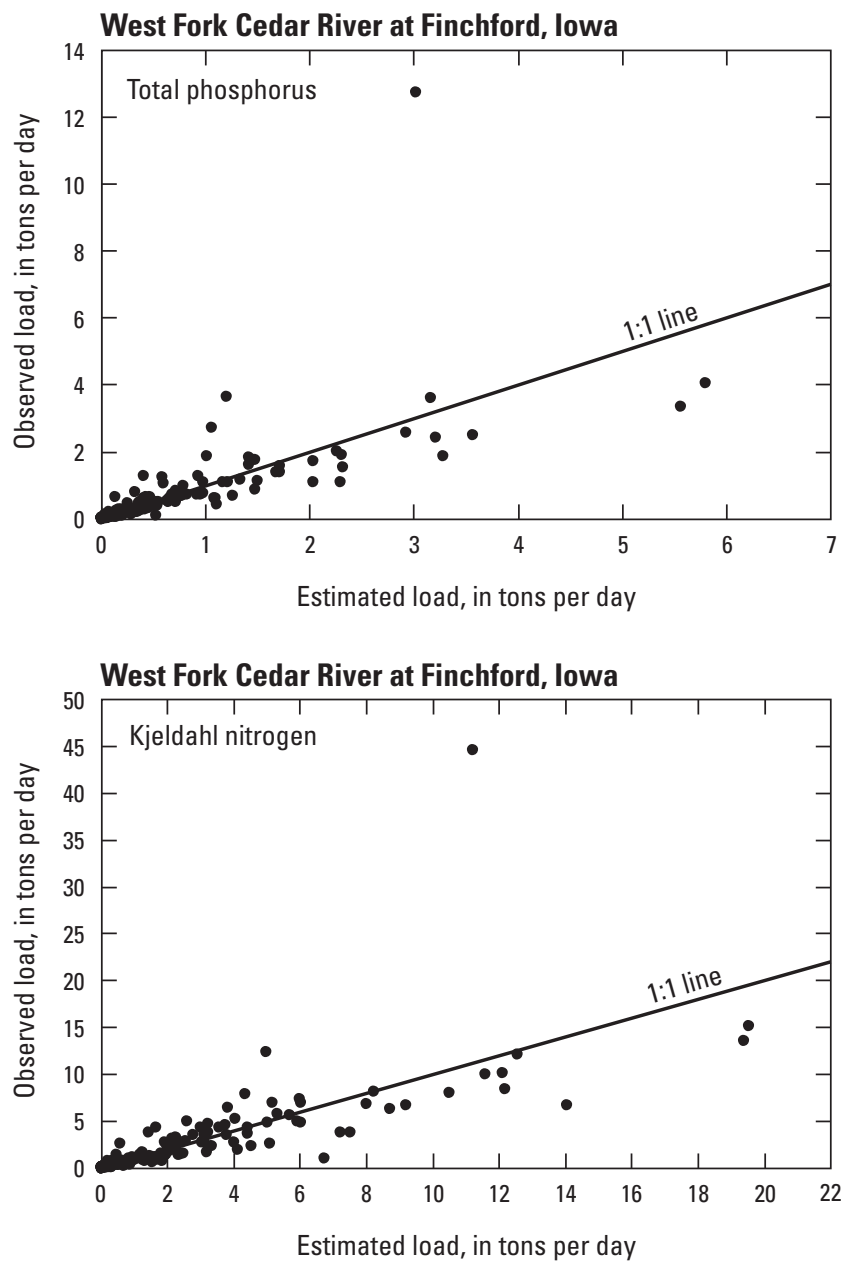

is the difference between the annual load at the downstream sampling site and the annual load at the upstream sampling site. Annual yield in the subbasin was the resulting load divided by the drainage area of the subbasin. Nutrient loads and yields for the Main Stem Upper Cedar River are based on the basin upstream from the sampling site at Charles City and include the Minnesota Cedar River subbasin.

\section{Statistical Methods}

Common nonparametric statistical methods that include the Kruskal-Wallis Test and the Wilcoxon Rank Sum Test were used to understand the magnitude of differences between nitrogen and phosphorus concentration, load, and yield in data grouped temporally and spatially (Helsel and Hirsch, 2002).

Nonparametric statistics were used because grouped datasets were relatively small and could not be assumed to be normally distributed. The Kruskal-Wallis Test was used to test if the median of two or more groups was the same. The Wilcoxon Rank Sum Test was used to test if median ranks from two related groups differ. Comparison between the relation
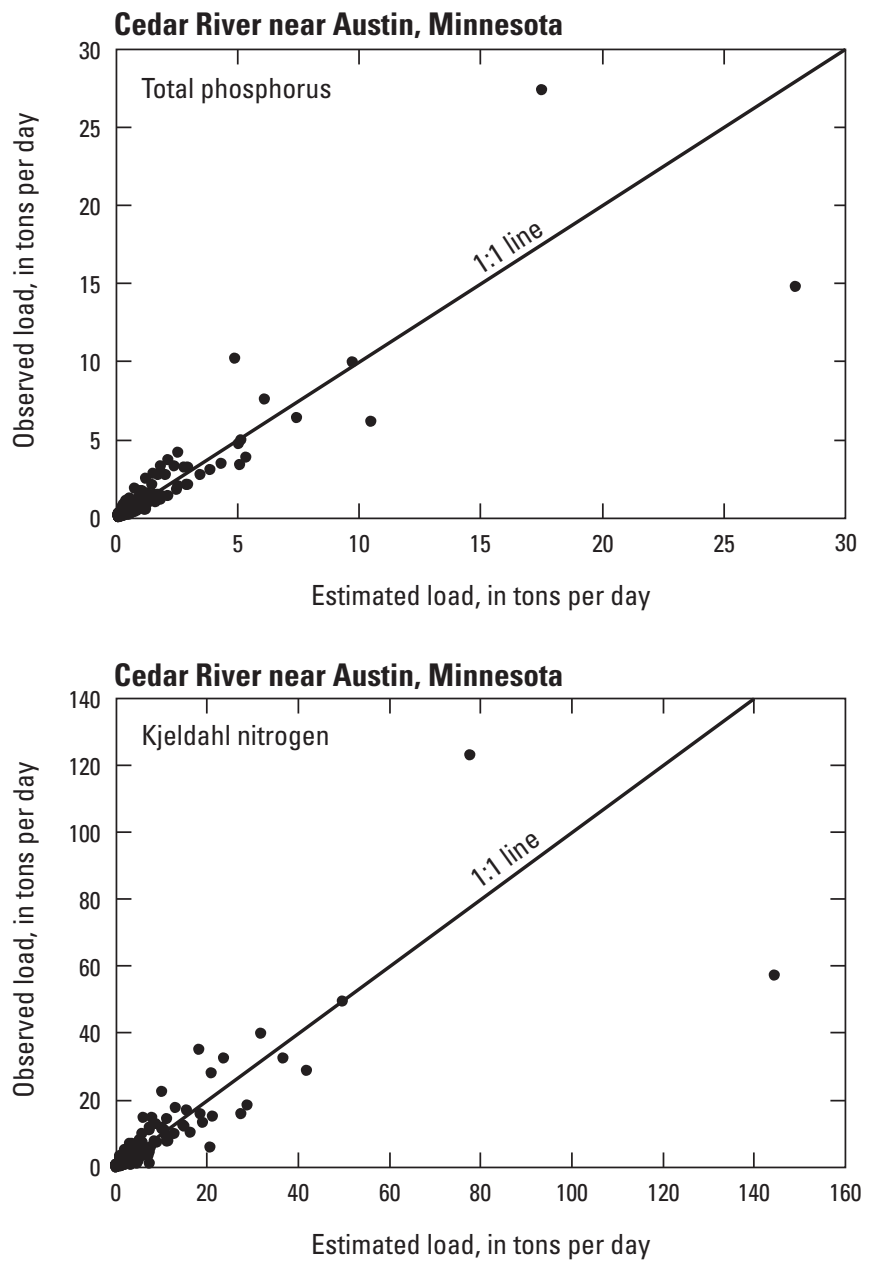

Figure 7. Observed daily total phosphorus and Kjeldahl nitrogen load in relation to the modeled daily load in the Cedar River near Austin, Minnesota, and in the West Fork Cedar River near Finchford, lowa, 2000-15. 
(regression line) of annual stream runoff and constituent yield in different subbasins was made using analysis of covariance (ANCOVA) (McDonald, 2014). ANCOVA was used to determine whether the slope or intercept of the regression lines are significantly different

\section{Transport of Nitrogen and Phosphorus During Base-Flow Periods}

The concentrations of the nitrogen and phosphorus species varied seasonally during base-flow conditions in the Cedar River Basin. The average nitrate and TN concentrations at the synoptic sampling sites were significantly $(p<0.05$, Kruskal-Wallis Test) less during dry fall conditions than during normal fall and spring conditions. Nitrate concentrations ranged from 0.04 to $8.02 \mathrm{mg} / \mathrm{L}$ during the dry fall conditions but ranged from $3.28 \mathrm{mg} / \mathrm{L}$ to $12.6 \mathrm{mg} / \mathrm{L}$ during more normal fall conditions (table 7). Nitrate concentrations at the synoptic sampling sites were greatest during spring when concentrations ranged from $5.01 \mathrm{mg} / \mathrm{L}$ to $17.4 \mathrm{mg} / \mathrm{L}$.

As with nitrate concentrations, TN concentrations were significantly ( $p<0.05$, Kruskal-Wallis Test) less during dry fall conditions than during normal fall conditions and spring conditions. The mean TN concentration during fall $(7.89 \mathrm{mg} / \mathrm{L})$ was more than twice the average concentration $(3.84 \mathrm{mg} / \mathrm{L})$ during dry fall conditions. The average $\mathrm{TN}$ concentration during spring was 36 percent greater than during fall and ranged from $6.11 \mathrm{mg} / \mathrm{L}$ to $17.7 \mathrm{mg} / \mathrm{L}$.

The proportion of nitrogen in the dissolved phase (nitrate) was not significantly different ( $p>0.05$, Kruskal-Wallis Test) during spring and normal fall conditions. Nitrate, on average, composed more than 90 percent of the nitrogen measured at the synoptic sites; however, this was not the case during dry fall base-flow conditions when, on average, nitrate composed 65 percent of the TN. The proportion of nitrate to TN also was extremely variable during dry fall conditions ranging from 1.3 to 96 percent. A significantly ( $p<0.05$, Kruskal-Wallis Test) greater proportion of the nitrogen in the streams during this period was in the particulate form (table 7), possibly incorporated into living organic compounds such as aquatic plants and algae.

Unlike nitrate, OP concentrations were greater during the fall base-flow conditions than during spring base flow. Average OP concentrations in the Cedar River Basins were $0.060 \mathrm{mg} / \mathrm{L}$ during the fall and $0.025 \mathrm{mg} / \mathrm{L}$ in the spring (table 7); however, during dry fall base-flow conditions, the average OP concentration was $0.039 \mathrm{mg} / \mathrm{L}$, slightly greater than the average spring concentration.

Concentrations of TP were not significantly $(p>0.05$ Kruskal-Wallis Test) different at the synoptic sites during spring, fall, or dry fall base-flow conditions. The average annual TP concentration in spring was $0.126 \mathrm{mg} / \mathrm{L}$ and was $0.121 \mathrm{mg} / \mathrm{L}$ in fall. Although there was much less water flowing in the streams and rivers, the average TP concentration $(0.185 \mathrm{mg} / \mathrm{L})$ was slightly greater during dry fall conditions than during normal fall base-flow and spring base-flow conditions.

The proportion of phosphorus in the dissolved phase (OP) was significantly greater $(p<0.05$, Kruskal-Wallis Test) during fall base-flow conditions than during spring and dry fall base-flow conditions. OP composed almost 49 percent of the phosphorus at the synoptic sites during fall, but composed an average of 30 percent and 21 percent of the TP during spring and dry fall conditions, respectively.

\section{Base-Flow Temporal Trends}

The nitrogen and phosphorus yield in subbasins in the Cedar River Basin was highly variable during base-flow conditions. Although differences were observed at a number of sites, there was no significant $(p>0.05)$ trend in nitrogen and phosphorus yields as whole from the beginning of the study period in the early 2000 s to the end of the study period in the early 2010s. The most significant differences were observed among spring high base flow, fall low base flow, and dry fall base-flow conditions. Spatial differences in yields were observed seasonally.

Nitrogen and phosphorus yield from 21 Cedar River subbasins generally were greater during spring and dry fall conditions in the early 2000 s than in the early 2010 s (table 8 ); for example, there was a significantly greater $(p<0.05$, Wilcoxon rank sum) average yield of nitrate, TN, and OP in May 2001 than in May 2011. A similar trend was observed during dry conditions when the average nitrate, TN, OP, and TP yields were significantly $(p<0.05$, Wilcoxon rank sum) greater earlier in the study period than in the latter part (table 8). In contrast, the average TN yield was significantly greater $(p<0.05$, Wilcoxon rank sum) during the latter part of the study in the fall of 2010 compared to the fall of 2000.

Nitrogen and phosphorus yields during dry fall conditions were consistently greater in 2002 than in 2012. The average nitrate, TN, OP, and TP yields were significantly $(p<0.05$, Wilcoxon rank sum) greater in 2002 than 2012 (table 8). These differences most likely were not the result of a long-term trend during the study but rather were the result of climatic conditions at the time each synoptic study was completed. Annual rainfall in 2012 was less than one-half that in 2002 in the study area (fig. 4), resulting in substantially less discharge in 2012 than in 2002 (fig. 5). Decreased transport from contributing basins, increased instream uptake by algae and plants, and increased instream denitrification (Mosley, 2015) during a period of smaller streamflow may result in smaller yields during increasingly dry conditions. 
Table 7. Seasonal variability in nitrogen and phosphorus concentration and yield at synoptic sampling sites in the Cedar River Basin, 2000-12.

[N, nitrogen; $\mathrm{P}$, phosphorus; $<$, less than $]$

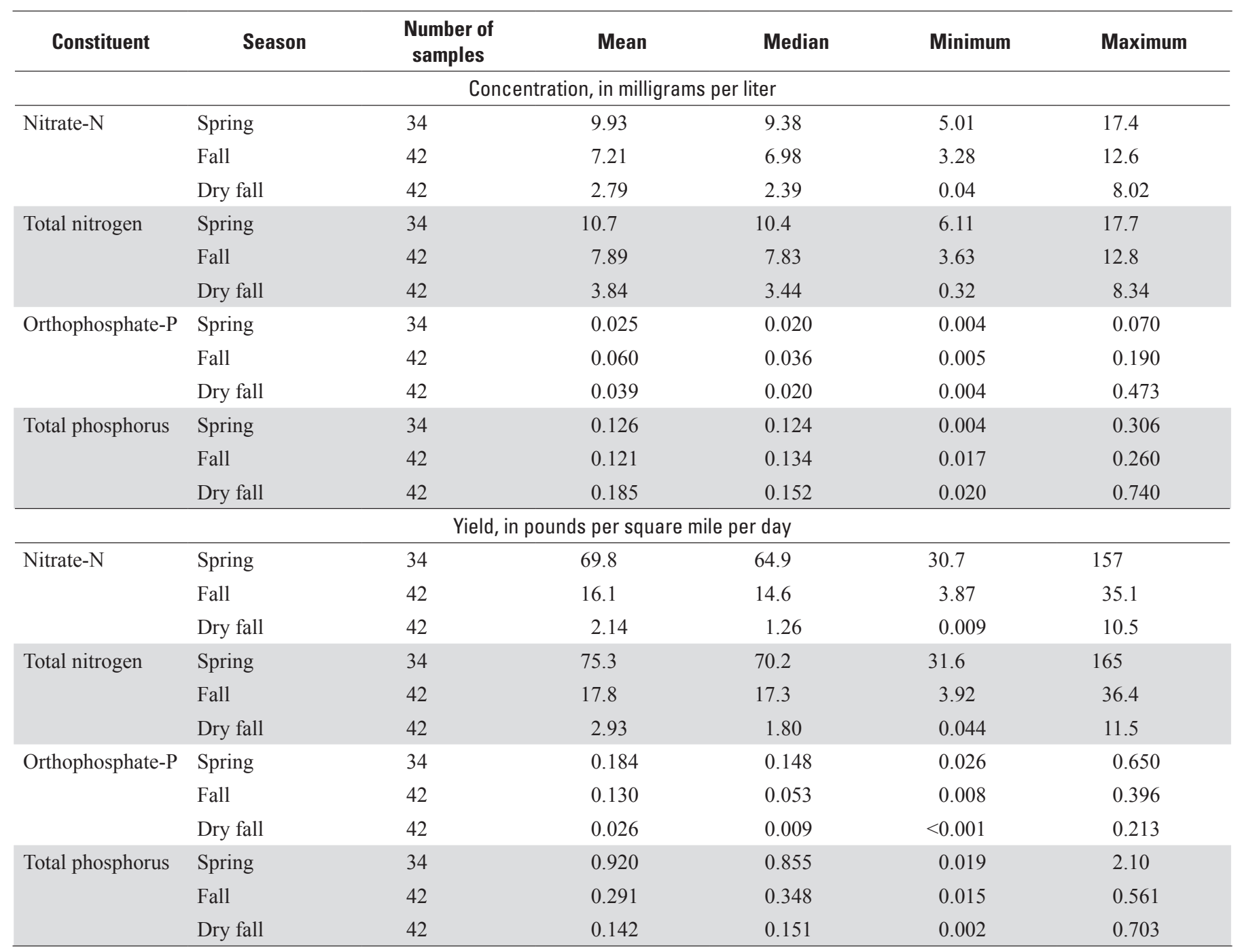


Table 8. Summary of daily nitrogen and phosphorus yields from synoptic subbasins in the Cedar River Basin during the early 2000 s in relation to those during the early 2010 s.

[N, nitrogen; $\mathrm{P}$, phosphorus; bold font indicates yield is significantly greater $(p<0.05$, Wilcoxon rank sum) $]$

\begin{tabular}{|c|c|c|c|c|c|c|}
\hline \multirow{2}{*}{ Date } & \multirow{2}{*}{ Constituent } & \multirow{2}{*}{$\begin{array}{l}\text { Number of } \\
\text { subbasins }\end{array}$} & \multicolumn{4}{|c|}{ Constituent yield, in pounds per square mile per day } \\
\hline & & & Minimum & Maximum & Mean & Median \\
\hline \multicolumn{7}{|c|}{ Spring } \\
\hline May 2011 & Nitrate-N & 21 & 30.7 & 86.2 & 57.0 & 50.8 \\
\hline May 2001 & Total nitrogen & 13 & 62.2 & 165 & 96.6 & 85.0 \\
\hline May 2001 & Orthophosphate-P & 13 & 0.049 & 0.650 & 0.280 & 0.298 \\
\hline May 2011 & Orthophosphate-P & 21 & 0.026 & 0.378 & 0.125 & 0.057 \\
\hline May 2001 & Total phosphorus & 13 & 0.019 & 1.79 & 1.04 & 1.32 \\
\hline May 2011 & Total phosphorus & 21 & 0.194 & 2.10 & 0.844 & 0.855 \\
\hline \multicolumn{7}{|c|}{ Fall } \\
\hline October 2010 & Total nitrogen & 21 & 4.26 & 36.4 & 20.7 & 18.9 \\
\hline November 2000 & Orthophosphate-P & 21 & 0.008 & 0.396 & 0.199 & 0.273 \\
\hline October 2010 & Orthophosphate-P & 21 & 0.008 & 0.272 & 0.061 & 0.025 \\
\hline November 2000 & Total phosphorus & 21 & 0.015 & 0.542 & 0.274 & 0.341 \\
\hline October 2010 & Total phosphorus & 21 & 0.048 & 0.561 & 0.307 & 0.356 \\
\hline \multicolumn{7}{|c|}{ Dry fall } \\
\hline September 2002 & Nitrate-N & 21 & 1.14 & 10.54 & 3.75 & 2.92 \\
\hline September 2012 & Nitrate-N & 21 & 0.01 & 3.04 & 0.52 & 0.40 \\
\hline
\end{tabular}




\section{Seasonal Variability During Base Flow}

Cedar River subbasins yielded more nitrogen and phosphorus during spring base-flow conditions than during fall base-flow conditions. Most of the nitrogen was in the dissolved species, but this varied by constituent and season.

The TN yield was significantly greater during spring when base flow and nitrogen concentrations are greater. The average TN yield in spring was 75.3 pounds per square mile per day $\left(\mathrm{lb} / \mathrm{mi}^{2} /\right.$ day $)$, more than 4.0 times the average yield $\left(17.8 \mathrm{lb} / \mathrm{mi}^{2} /\right.$ day) during fall base flow (table 7). During the dry falls of 2002 and 2012, the average TN yield was even less $\left(2.93 \mathrm{lb} / \mathrm{mi}^{2} /\right.$ day $)$ than during a fall with normal rainfall. Most of the nitrogen from the subbasins is in the dissolved form, nitrate. The average nitrate during the spring was $69.8 \mathrm{lb} / \mathrm{mi}^{2} /$ day and was $16.1 \mathrm{lb} / \mathrm{mi}^{2} /$ day during fall base-flow conditions. The average nitrate yield during spring was 93 percent of the average TN yield. The proportion of the TN in the form of nitrate during the fall was slightly less (about 90 percent). During dry fall base flow conditions, a smaller proportion (73 percent) of the TN yield was as nitrate.

As with nitrogen, subbasins in the Cedar River Basin on average yielded greater amounts of TP during spring base-flow conditions than were yielded during fall base-flow conditions. Average TP yield in spring was $0.92 \mathrm{lb} / \mathrm{mi}^{2} /$ day; more than 3.0 times the average yield $\left(0.29 \mathrm{lb} / \mathrm{mi}^{2} /\right.$ day $)$ during fall base flow (table 7). During the dry falls of 2002 and 2012, the average TP yield was even less $\left(0.14 \mathrm{lb} / \mathrm{mi}^{2} /\right.$ day $)$ than during a fall with normal rainfall. Most of the phosphorus transported from the subbasins is in the particulate form. The average OP yield during spring was about 20 percent of the average TP yield. The proportion of the TP in the form of OP during the fall was slightly greater (about 45 percent). During dry fall base-flow conditions, 18 percent of the TP yield was as OP.

\section{Spatial Differences During Base-Flow Conditions}

In addition to the seasonal variability in nitrogen and phosphorus yields, there were distinct spatial differences in nitrogen and phosphorus yields among subbasins during baseflow conditions.

The average $\mathrm{TN}$ yields during the two spring base-flow synoptic studies were greater than $50 \mathrm{lb} / \mathrm{mi}^{2} /$ day in all subbasins except for three subbasins adjacent to the main stem of the Cedar River downstream from Waterloo (fig. 8) where the average $\mathrm{TN}$ yields were less than $25 \mathrm{lb} / \mathrm{mi}^{2} /$ day. However, the average nitrate yields during spring base flow were greater than $50 \mathrm{lb} / \mathrm{mi}^{2} /$ day only in subbasins upstream from Waterloo in the Upper Cedar River Basin and in Blackhawk, Beaver, and Wolf Creek subbasins in the Middle Cedar River Basin (fig. 8). Spring nitrate yields from subbasins along the main stem of the Cedar River downstream from Waterloo generally were less than $25 \mathrm{lb} / \mathrm{mi}^{2} /$ day (fig. 8). The difference in yield between the TN and nitrate in the Lower four subbasins indicates that these areas contributed a greater proportion of organic nitrogen and ammonia in relation to nitrate than did subbasins upstream from Waterloo.

Generally, the nitrate and TN yield were more uniform throughout the Cedar River Basin in the fall. The TN yield in several main stem Cedar River Basins was 0.0 or less. A zero or negative calculated yield indicates that the amount of nitrogen leaving the subbasin was equal to or less than what was entering the subbasin. Conditions in the river in the fall were suitable for uptake of nitrogen by algae and plants and streambed denitrification; processes that could remove nitrogen from the water column.

During dry fall conditions, the nitrate and TN yields are uniform throughout the Cedar River Basin. Except for the Cedar River just upstream of Cedar Falls, the average nitrate and TN yield was less than $25 \mathrm{lb} / \mathrm{mi}^{2} /$ day (fig. 8).

Phosphorus yield was not uniform across the Cedar River Basin during base-flow conditions in the early 2000s and 2010s. The average OP and TP yield for each subbasin ranged from $0.0 \mathrm{lb} / \mathrm{mi}^{2} /$ day or less (net loss) to more than $1.5 \mathrm{lb} / \mathrm{mi}^{2} /$ day and was variable from parts of the Cedar River Basin during spring and fall base-flow conditions (fig. 9).

Several basins had a net yield of $0.0 \mathrm{lb} / \mathrm{mi}^{2} /$ day or a loss of OP and TP. These subbasins may have contributed small amounts of phosphorus during the synoptic studies, but the yield may have been less than could be measured using the techniques described earlier. Subbasins that yielded no measurable OP in spring included parts of the Upper Cedar River (site S3) and several Cedar River main stem subbasins downstream from Waterloo, Iowa (sites S11, S15, and S16). During the fall, several subbasins (sites S2, S4, S15, and S20) scattered throughout the Cedar River Basin yielded no OP (fig. 9A). During dry fall conditions, an area upstream from Waterloo, Iowa, along the main stem of the Cedar River did not contribute additional OP to the river (fig. $9 \mathrm{~A}$ ). A net loss or $0.0 \mathrm{lb} / \mathrm{mi}^{2} /$ day yield of TP was only at a small number of sites during low base-flow conditions in the fall (fig. $9 B$ ).

There was a consistent pattern of the largest OP and TP yields in the western subbasins in the Upper and Middle Cedar River Basin during spring base-flow conditions. These subbasins were drained by the Shell Rock and the West Fork Cedar Rivers, and Beaver, Black Hawk, and Wolf Creeks. Only two subbasins (sites S15 and S21) on the main stem of the Cedar River yielded more TP than these subbasins.

As expected, the OP and TP yields during fall base flow generally was less than during spring base-flow conditions and the greatest yields now were in subbasins that included the cities of Waterloo and Cedar Rapids, Iowa. 

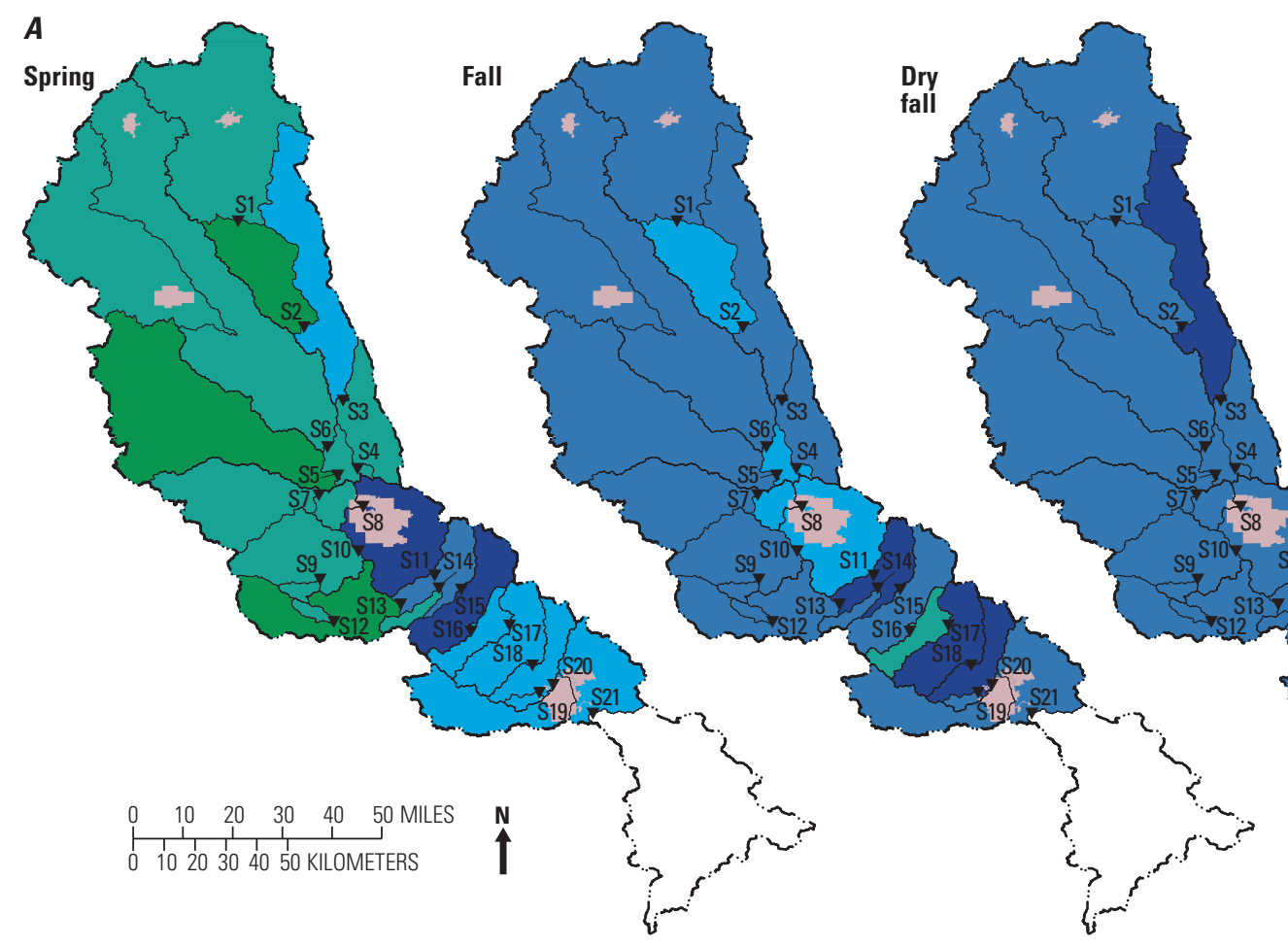

EXPLANATION

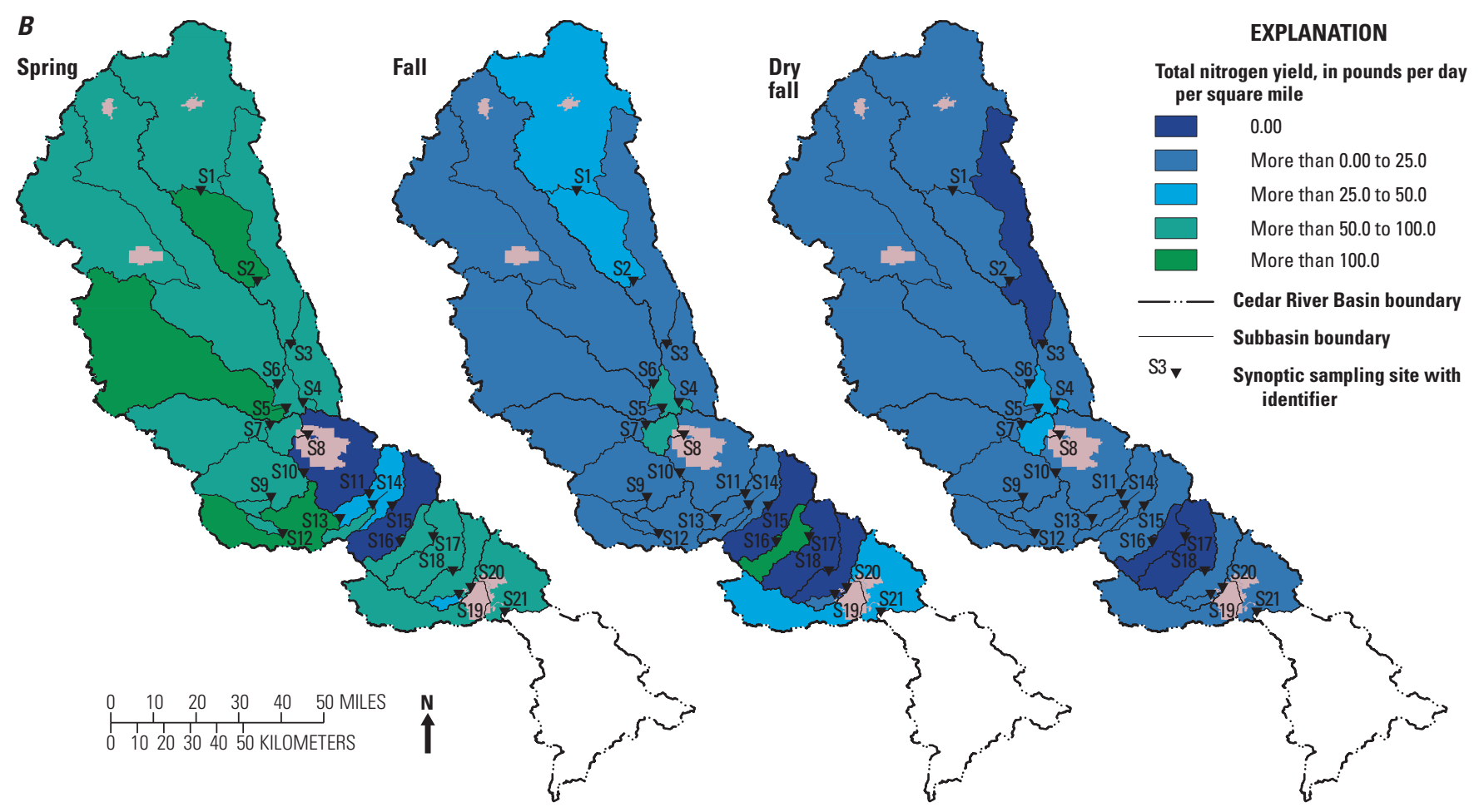

Figure 8. Nitrogen yield during spring $(2001,2011)$, fall $(2000,2010)$, and dry fall $(2002,2012)$ base-flow conditions in Cedar River subbasins. $A$, nitrate nitrogen yield. $B$, total nitrogen yield. 
A

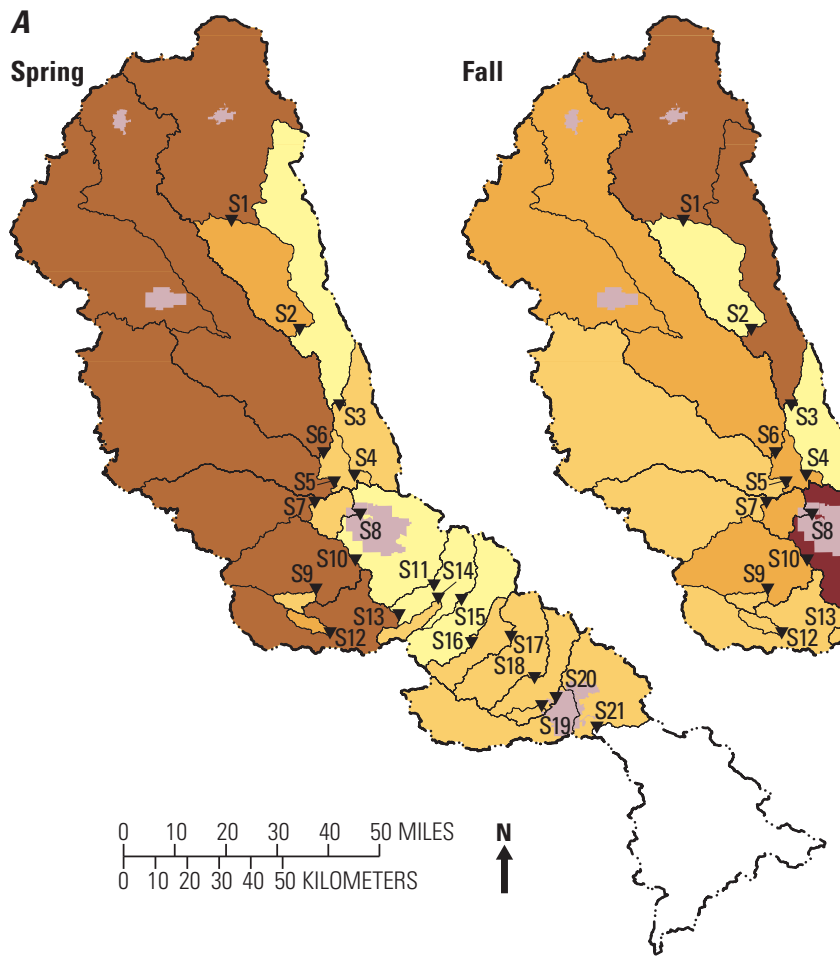

\section{B}

B

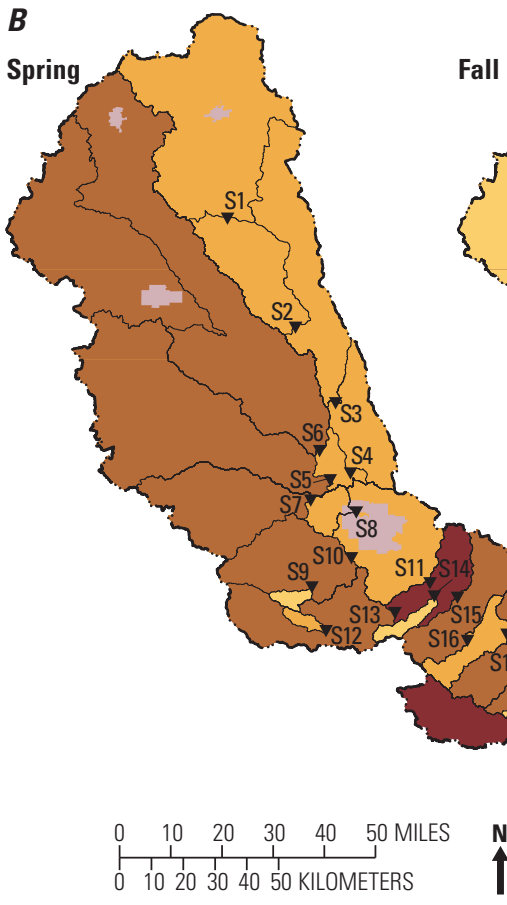

Dry<smiles>C1=CCCCC1</smiles><smiles>C1CCCCC1</smiles><smiles>C1CC2CCCC2C1</smiles><smiles>C1C2CC3CC1C3C2</smiles><smiles>C1CCC2CCCC2C1</smiles><smiles>C1CCCC1</smiles><smiles>C1CCCCC1</smiles>

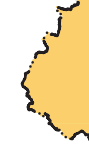
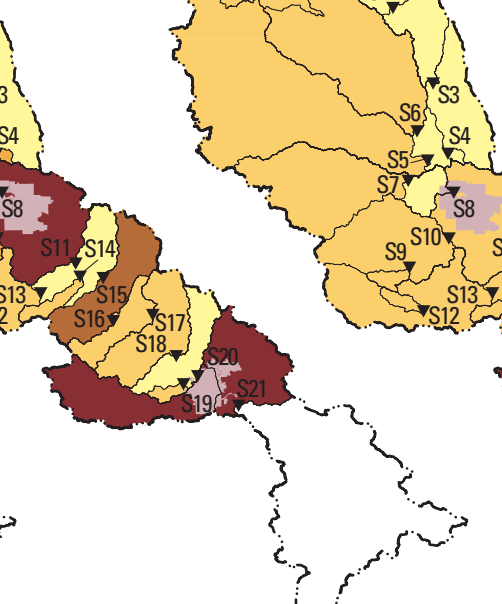

\section{EXPLANATION}

Orthophosphate phosphorus yield,

in pounds per day per square mile 0.00

More than 0.00 to 0.10

More than 0.10 to 0.20

More than 0.20 to 0.50

More than 0.50

Cedar River Basin boundary

Subbasin boundary

Synoptic sampling site with identifier
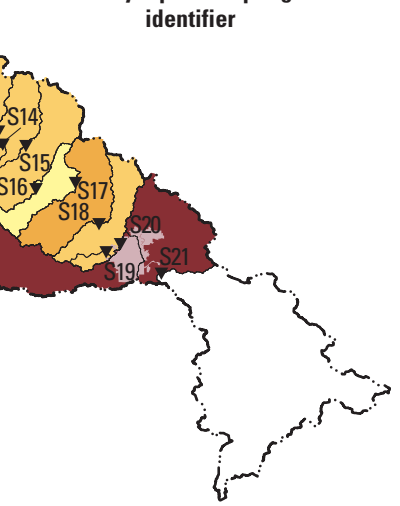

\section{EXPLANATION}

Total phosphorus yield, in pounds per day per square mile

More than 0.00 to 0.50

More than 0.50 to 1.00

More than 1.00 to 1.50

More than 1.50

Cedar River Basin boundary

Subbasin boundary

Synoptic sampling site with identifier

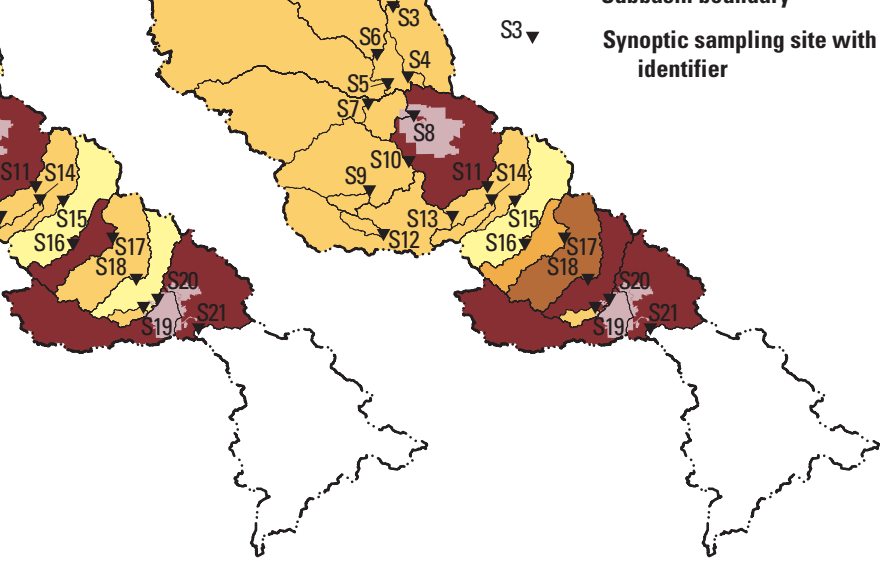

Figure 9. Phosphorus yield during spring $(2001,2011)$, fall $(2000,2010)$, and dry fall $(2002,2012)$ base-flow conditions in Cedar River subbasins. $A$, Orthophosphate. $B$, Total phosphorus. 


\section{Transport of Nitrogen and Phosphorus, 2000-15}

The annual average TN load transported from the Cedar River Basin to the Iowa River from 2000 to 2015 was 53,100 tons (table 9 ). The annual load varied substantially from 15,400 tons in 2012, which was drier than normal (annual runoff of $4.53 \mathrm{in}$.), to 102,000 tons in 2008 during wet (annual runoff of 24.6 in.) climatic conditions. Most (about 82 percent) of the nitrogen transported from the Cedar River Basin was in the dissolved nitrate form. The annual dissolved nitrate load averaged 43,900 tons and ranged from 10,900 to 84,700 tons/yr. As with TN loads, the smallest annual nitrate loads were in 2012 and the largest in 2008. The annual average nitrogen load transported from the Cedar River Basin represents a yield (loss) of $21.3 \mathrm{lb} /$ acre and $17.6 \mathrm{lb} / \mathrm{acre}$ for TN and nitrate, respectively (table 9). The 2000-15 TN yield was less than the estimated average annual TN yield of $26.6 \mathrm{lb} / \mathrm{acre}$ from the Cedar River Basin in 1996-98 (Becher and others, 2001).

The annual average TP load transported from the Cedar River Basin in 2000-15 was 2,510 tons and ranged from 934 to 5,970 tons (table 9). The smallest amount of TP was during 2012 and the greatest during 2008. The annual OP load averaged 930 tons and ranged from 251 tons in 2002 to 2,060 tons in 2008. In contrast to nitrogen, much of the phosphorus transported from the Cedar River Basin was in the particulate form. An average of 37 percent of the phosphorus was transported as dissolved OP. The average annual phosphorus load transported from the Cedar River Basin represents an annual phosphorus loss of $1.01 \mathrm{lb} /$ acre of TP and $0.37 \mathrm{lb} / \mathrm{acre}$ of OP. The annual yield for 2000-15 was greater than the estimated annual TP yield of $0.86 \mathrm{lb} /$ acre for 1996-98 (Becher and others, 2001).

\section{Upper, Middle, and Lower Cedar River Basins}

The Upper Cedar River Basin contributed the largest amount of nitrogen from the Cedar River Basin in 2000-15. On average, about 30,000 tons per year (tons/yr) of TN were transported from the Upper Cedar River Basin followed by 14,900 tons/yr of TN from the Middle Cedar River Basin and 9,760 tons/yr from the Lower Cedar River Basin (table 9). The average amount of TN lost per acre per year was similar in the Upper (22.0 lb/acre) and Middle (22.3 lb/acre) Cedar River Basins during the 2000-15 study. A slightly smaller amount of TN was lost $(21.1 \mathrm{lb} / \mathrm{acre})$ from the Lower Cedar River Basin. Much of the nitrogen transported was in the form of dissolved nitrate. Of the 30,000 tons/yr transported from the Upper Cedar River Basin, an average of about 87 percent (26,000 tons) was as nitrate (table 9). Nitrate constituted about 84 percent $(12,500$ tons/yr) of the nitrogen transported from the Middle Cedar River Basin and about 70 percent (6,860 tons/yr) of the nitrogen transported from the Lower Cedar River Basin.
Nitrogen transport from 2000 to 2015 in the Upper, Middle, and Lower Cedar River Basins was highly variable. Nitrogen transport was greatest in 2008, when runoff was the highest, and lowest in 2012 during drought conditions that resulted in little runoff. TN and nitrate transport in 2008 were commonly an order of magnitude greater than in 2012. The maximum TN transport was 53,600 tons/yr from the Upper Cedar River Basin, 28,700 tons/yr from the Middle Cedar River Basin, and 23,400 tons/yr from the Lower Cedar River Basin. The annual yield of TN in the Upper, Middle, and Lower Cedar River Basins ranged from less than $4.0 \mathrm{lb} / \mathrm{acre}$ to $50 \mathrm{lb} /$ acre or more.

In contrast to nitrogen, the largest amount of phosphorus was transported from the Lower Cedar River Basin. An annual average of 1,020 tons/yr of TP was transported from the Lower Cedar River Basin. This annual average was 187 tons/yr more than from the Upper Cedar River Basin (833 tons/yr) and 290 tons/yr more than from the Middle Cedar River Basin (730 tons/yr) (table 9). The dissolved OP constituted about 39 percent of the TP transported from the Upper Cedar River Basin, about 37 percent of the TP transported from the Middle Cedar River Basin, and 31 percent of the TP transported from the Lower Cedar River Basin. As with nitrogen, phosphorus transport was extremely variable from 2000 to 2015 . The maximum annual TP transported from the Upper and Middle Cedar River Basins differed by more than an order of magnitude. Annual TP transported was more uniform in the Lower Cedar River Basins, ranging from 470 tons/yr in 2012 to 1,960 tons/yr in 2008. Loss of phosphorus from the Lower Cedar River Basin (TP yield of $2.21 \mathrm{lb} / \mathrm{acre}$ ) was more than 2 times that from the Middle Cedar River Basin (TP yield of $1.09 \mathrm{lb} / \mathrm{acre})$ and 3.6 times that from the Upper Cedar River Basin (TP yield of $0.61 \mathrm{lb} / \mathrm{acre}$ ).

\section{Long-Term Monitoring Subbasins}

Although the amount of nitrogen and phosphorus transported from the Upper and Middle Cedar River Basins was similar, transport was variable from smaller subbasins within the basins. The load and yield varied from year to year.

\section{Nitrogen}

As expected, larger amounts of nitrogen and phosphorus were transported from the larger subbasins. The largest average annual TN load for the 2000-15 study period was from the Lower Cedar River subbasin. The largest average annual TN load was 9,470 tons from this 1,445- $\mathrm{mi}^{2}$ subbasin (table 10). The 655-mi ${ }^{2}$ Main Stem Upper Cedar River subbasin had the second greatest average annual TN load with 9,380 tons, and the third greatest annual average ( 8,130 tons) was from the

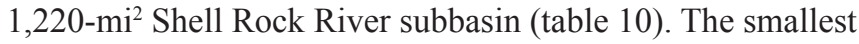
average annual TN load (2,760 tons) was transported from the 526-mi ${ }^{2}$ Upper Winnebago River subbasin (table 10), which is nested within the Shell Rock River subbasin. The Little 


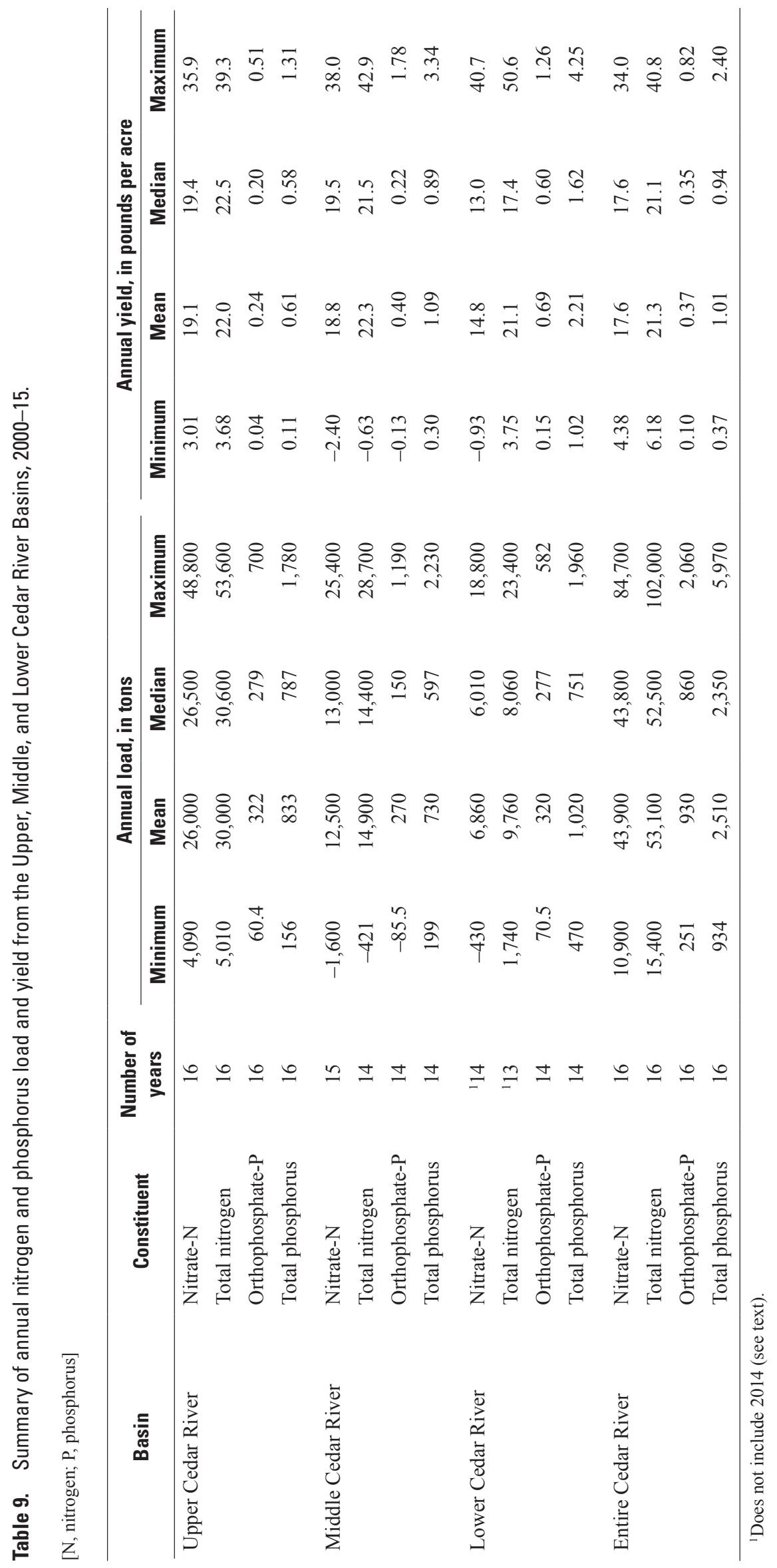


Cedar River subbasin contributed one of the smallest average annual TN loads ( 3,170 tons). Three Cedar River tributaries, Beaver, Black Hawk, and Wolf Creeks in the Middle Cedar River Basin, discharged an annual average of 3,400 tons or less (table 10).

Most of the nitrogen transported in rivers and streams was in the dissolved nitrate form. The dissolved part of the TN load varied from subbasin to subbasin in the Cedar River Basin. Dissolved nitrate comprised more than 80 percent of the TN transported from all but two subbasins (the Main Stem Middle Cedar River and the Lower Cedar River). The largest percentage of TN transported as nitrate was more than 90 percent in the Black Hawk Creek and West Fork Cedar River subbasins. In the remaining seven subbasins, between 80 and 90 percent of the TN was transported as nitrate; however, the largest amounts of nitrate were not always transported from the largest subbasins. An annual average of 6,700 tons of nitrate was transported from the largest subbasin, the Lower Cedar River (table 10). This was almost 1,500 tons/yr less than from the third largest subbasin, the Main Stem Upper Cedar River, and was similar to the nitrate (6,790 tons/yr) transported from the Shell Rock River, the second largest subbasin.

Although average annual TN loads were some of the smallest measured, Beaver Creek, Black Hawk Creek, and Wolf Creek subbasins in the Middle Cedar River Basin yielded the largest amount of TN on a per acre basis. These subbasins yielded an annual average of more than $30 \mathrm{lb} / \mathrm{acre}$, of which more than $25 \mathrm{lb} /$ acre were as nitrate. The smallest annual TN yield was from the Main Stem Middle Cedar River subbasin and the Little Cedar River subbasin. The two Shell Rock River subbasins (Upper Winnebago River and Shell Rock River) also yielded some of the smallest amounts of TN (table 10).

\section{Phosphorus}

The average annual TP load ranged from 63 tons in the Little Cedar River subbasin to 981 tons from the Lower Cedar River subbasin. As with TN, the largest average annual load originated from the largest subbasin, but TP loads did not always correlate with the size of the subbasin; for example, the second greatest annual average load (381 tons) was transported from the Main Stem Middle Cedar River subbasin, a subbasin about one-half the size (table 5) of the second largest subbasin (Shell Rock River). The Main Stem Upper Cedar River and Shell Rock River subbasins transported more than 260 tons of TP yearly.

The dissolved OP load generally was less than 50 percent of the TP load, but this proportion varied throughout the Cedar River Basin; however, the average proportion of OP to TP was 59 and 55 percent in the Minnesota Cedar River and Main Middle Cedar River subbasins, respectively. The dissolved OP load part of the TP load was less than 20 percent in the Wolf Creek subbasin, which is less than reported in other Iowa agricultural basins (Schilling and others, 2017b).

The average annual OP yield ranged from 0.160 tons/acre to 0.800 tons/acre, and the average annual TP yield ranged from 0.351 tons/acre to 2.12 tons/acre. Generally, the subbasin with the largest average annual loads of OP and TP were the same subbasins with the largest yields of these constituents on a per acre basis. The Lower Cedar River subbasin yielded $2.12 \mathrm{lb} / \mathrm{acre}$ of TP and $0.800 \mathrm{lb} / \mathrm{acre}$ of OP. Beaver Creek, Wolf Creek, and Main Stem Middle Cedar River subbasins also yielded more than $1.00 \mathrm{lb} /$ acre (table 10). In contrast, the average annual TP yield from the Little Cedar River subbasin $(0.351 \mathrm{lb} / \mathrm{acre})$ was only about 16 percent of the yield from the greatest TP yielding Lower Cedar River subbasin.

\section{Spatial Variability}

The transport of nitrogen and phosphorus was not uniform across subbasins in the Cedar River Basin in the decade and a half that extended from 2000 to 2015. Instead, the annual nitrogen and phosphorus yields varied spatially (see appendix 1).

\section{Nitrogen}

The greatest nitrogen yielding areas were from subbasins drained by Cedar River tributaries in the Middle Cedar River Basin (fig. 10). The average annual TN yield from the Beaver Creek, Black Hawk Creek, and Wolf Creek subbasins exceeded $30 \mathrm{lb} / \mathrm{acre}$. The smallest TN yielding subbasins were the Little Cedar River, Upper Winnebago River, Shell Rock River, and Main Middle Cedar River subbasins. The annual average yield in these subbasins was from 15 to about $20 \mathrm{lb} /$ acre. Nitrate, which composes most of the TN transported in the Cedar River (see previous discussion), was lost from subbasins in a similar pattern. The smallest nitrate yielding subbasins were in the most downstream part of the Cedar River Basin. The nitrate yield in the Main Stem Middle Cedar River and the Lower Cedar River subbasins was $15 \mathrm{lb} /$ acre or less (fig. 10). The nitrate yield from major Cedar River tributaries, West Fork Cedar River, Beaver Creek, Black Hawk Creek, and Wolf Creek as well as the Upper Cedar River subbasins Minnesota Cedar River and Main Stem Upper Cedar River subbasins was from 20 to $30 \mathrm{lb} / \mathrm{acre}$. The Shell Rock River and its nested subbasin, the Upper Winnebago River, and the Little Cedar River subbasins yielded from 15 to $20 \mathrm{lb} /$ acre (fig. 10).

\section{Phosphorus}

The average annual TP yield generally increased from the headwaters in Minnesota to the mouth of the Cedar River in Iowa (fig. 11). The average annual TP ranged from $0.50 \mathrm{lb} /$ acre or less in the Upper Cedar River Basin to $2.0 \mathrm{lb} / \mathrm{acre}$ or less in the Middle Cedar River Basin and more than $2.0 \mathrm{lb} / \mathrm{acre}$ in the Lower Cedar River Basin (fig. 11).

The greatest average annual OP yields were in the most upstream Minnesota Cedar River subbasin and the most downstream Main Stem Middle Cedar River and the Lower Cedar River subbasins that contain large urban areas. The average annual TP yield was less than $1.00 \mathrm{lb} / \mathrm{acre}$ in all Upper Cedar River subbasins (fig. 11). 


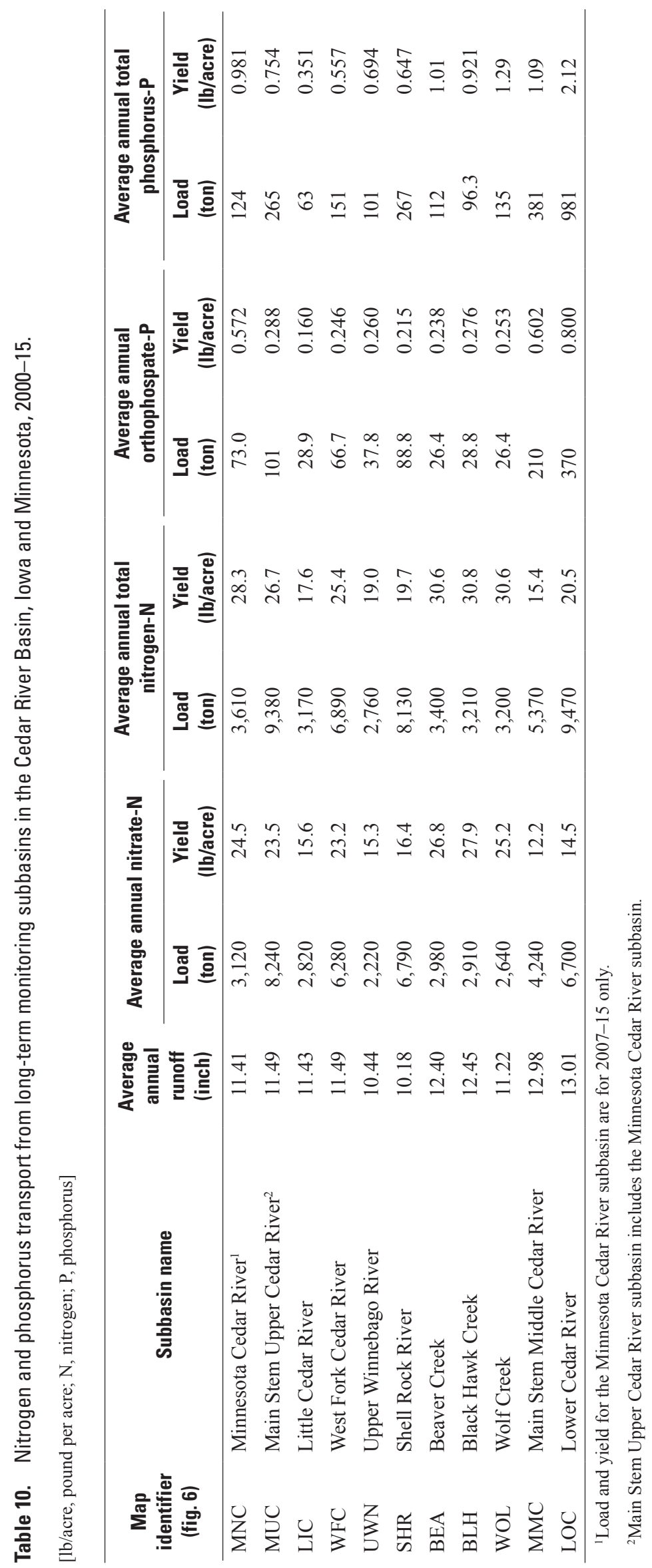




\section{A. Nitrate nitrogen}

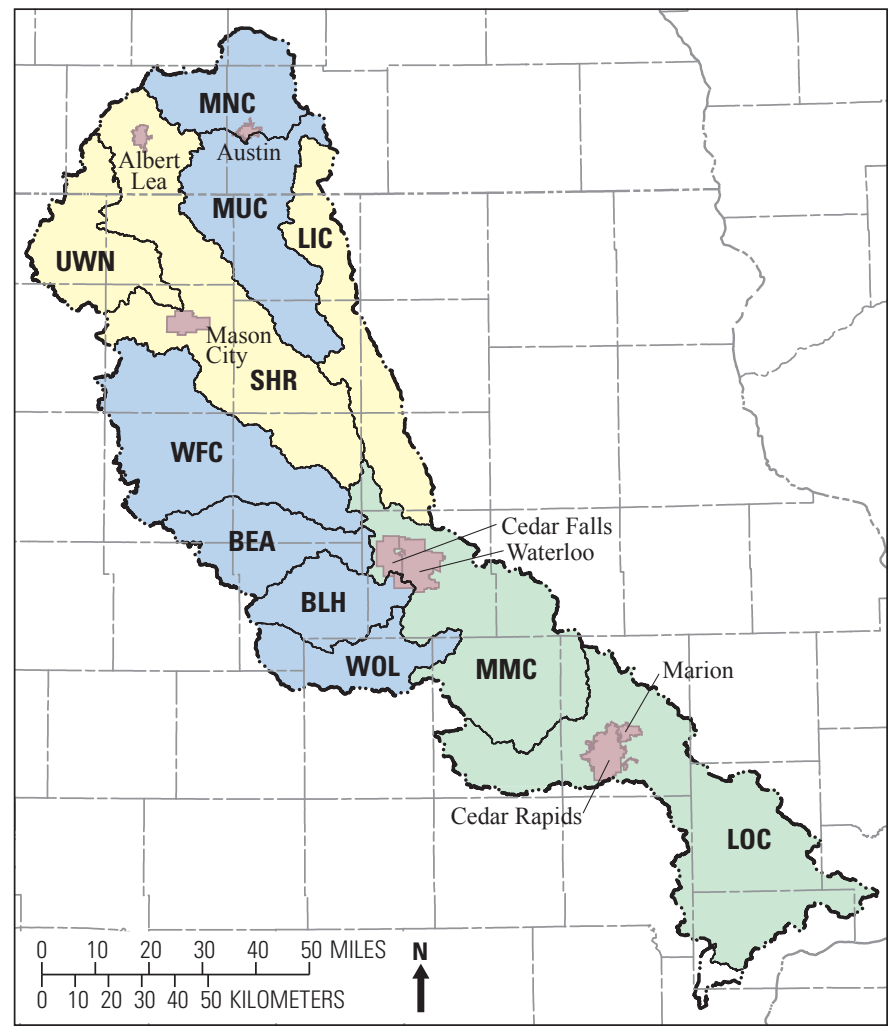

B. Total nitrogen as nitrogen

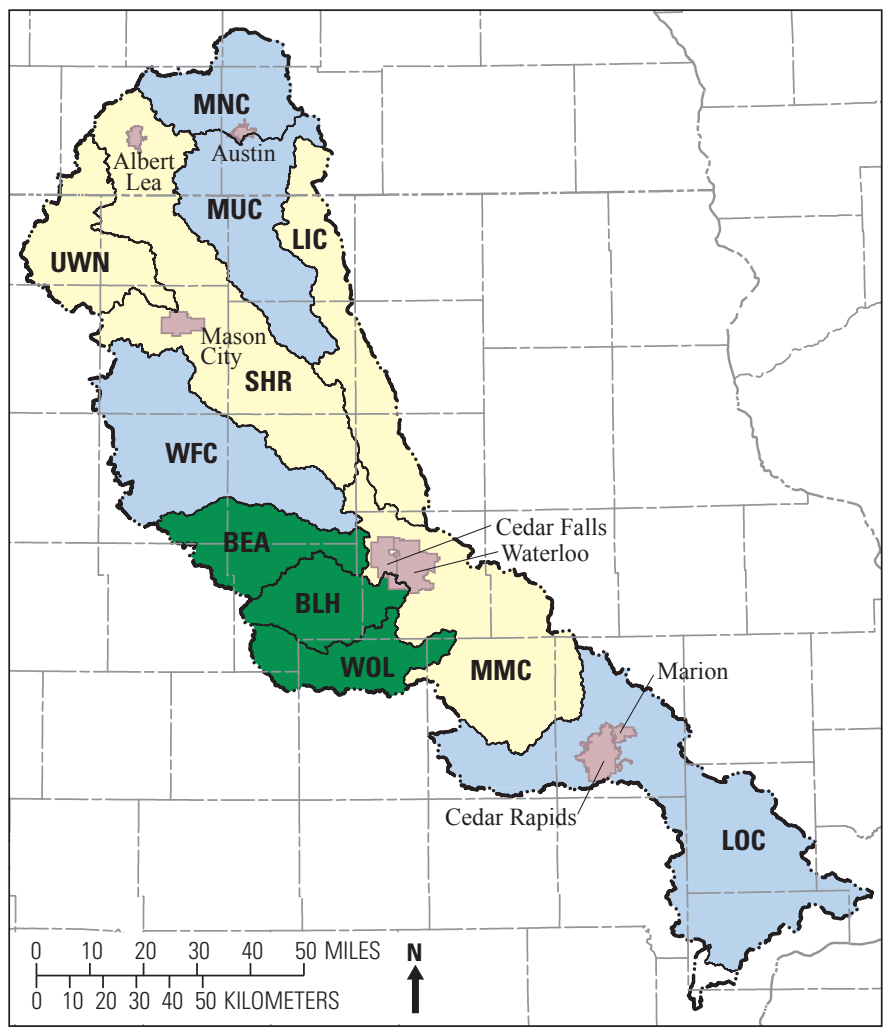

\section{EXPLANATION}

\begin{tabular}{|c|c|}
\hline \multicolumn{2}{|c|}{ Average annual yield, in pounds per acre } \\
\hline 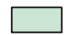 & 15.0 or less \\
\hline & More than 15.0 to 20.0 \\
\hline & More than 20.0 to 30.0 \\
\hline & More than 30.0 \\
\hline & Cedar River Basin boundary \\
\hline HB & Subbasin boundary and identif \\
\hline & Subbasin abbreviations \\
\hline MNC & Minnesota Cedar River \\
\hline MUC & Main Stem Upper Cedar River \\
\hline LIC & Little Cedar River \\
\hline WFC & West Fork Cedar River \\
\hline UWN & Upper Winnebago River \\
\hline SHR & Shell Rock River \\
\hline BEA & Beaver Creek \\
\hline BLH & Black Hawk Creek \\
\hline WOL & Wolf Creek \\
\hline MMC & Main Stem Middle Cedar Rive \\
\hline LOC & Lower Cedar River \\
\hline
\end{tabular}

Figure 10. Spatial variability of the average annual yield of nitrate nitrogen and total nitrogen in long-term monitoring subbasins in the Cedar River Basin, 2000-15. 
A. Dissolved orthophosphate phosphorus

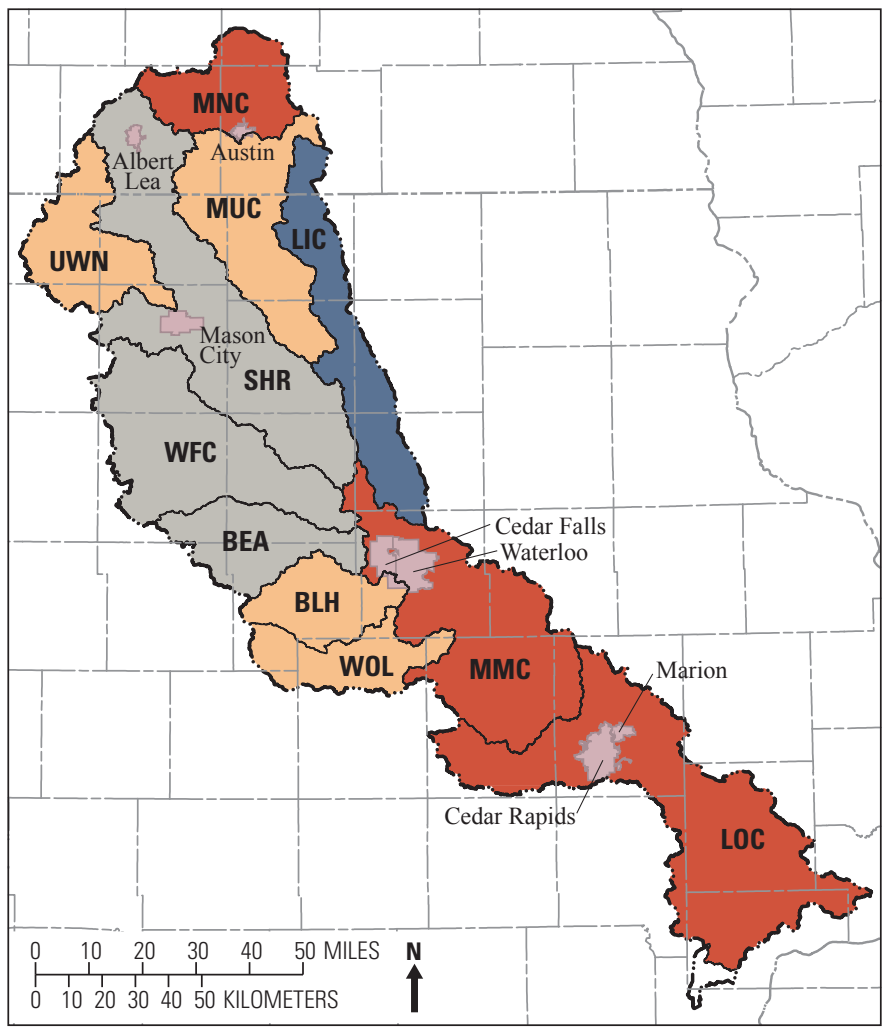

B. Total phosphorus

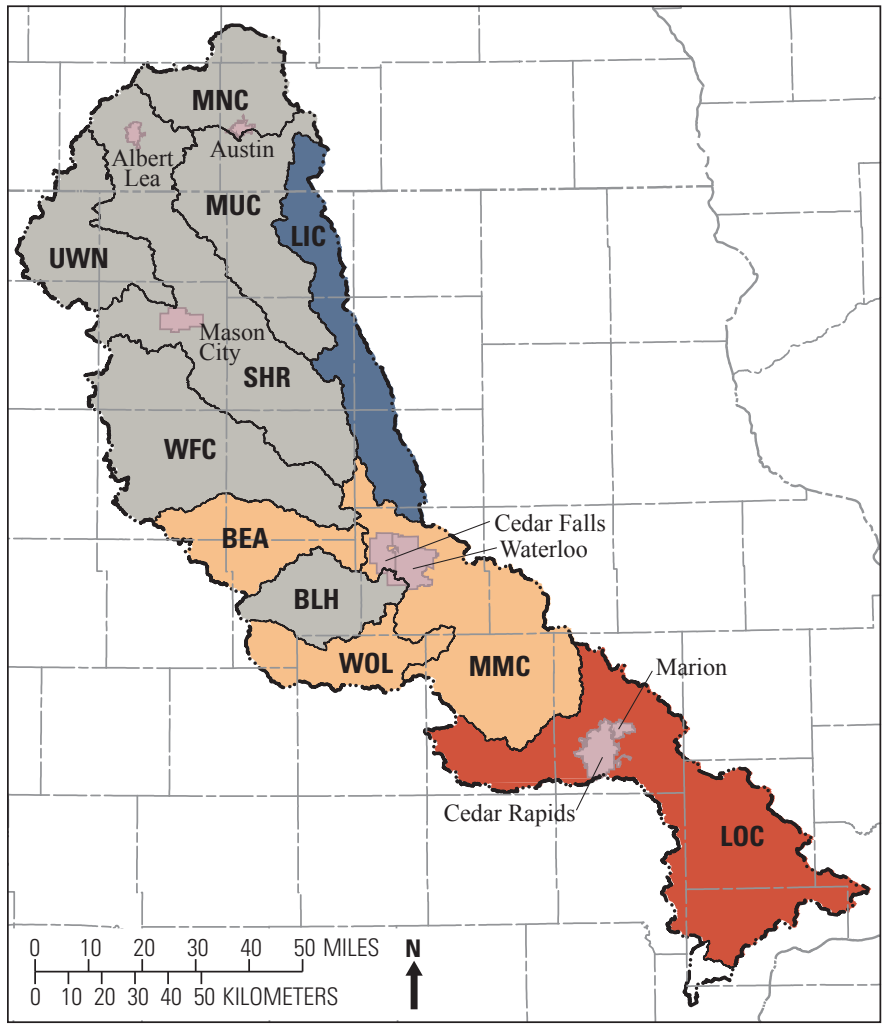

\section{EXPLANATION}

Average annual yield of dissolved orthophosphate phosphorus, in pounds per acre

0.20 or less

More than 0.20 to 0.25

More than 0.25 to 0.30

$\square \quad$ More than 0.30

$\begin{array}{cc}\text { _-.._ } & \text { Cedar River Basin boundary } \\ \text {-SHR - } & \text { Subbasin boundary and identifier } \\ & \text { Subbasin abbreviations } \\ \text { MNC } & \text { Minnesota Cedar River } \\ \text { MUC } & \text { Main Stem Upper Cedar River } \\ \text { LIC } & \text { Little Cedar River } \\ \text { WFC } & \text { West Fork Cedar River } \\ \text { UWN } & \text { Upper Winnebago River } \\ \text { SHR } & \text { Shell Rock River } \\ \text { BEA } & \text { Beaver Creek } \\ \text { BLH } & \text { Black Hawk Creek } \\ \text { WOL } & \text { Wolf Creek } \\ \text { MMC } & \text { Main Stem Middle Cedar River } \\ \text { LOC } & \text { Lower Cedar River }\end{array}$

Average annual total phosphorus yield, in pounds per acre

0.50 or less

More than 0.50 to 1.00

More than 1.00 to 2.00

More than 2.00

Figure 11. Spatial variability of the average annual yield of dissolved orthophosphate and total phosphorus in long-term monitoring subbasins in the Cedar River Basin, 2000-15. 


\section{Temporal Trend}

The transport of nitrogen and phosphorus varied spatially among subbasins and varied year to year from 2000 to 2015 . The amount of nitrogen and phosphorus transported from 11 subbasins within the Cedar River Basin, except for TP from two subbasins, did not change significantly $(p>0.05)$ during $2000-15$. Transport was correlated significantly $(p<0.05)$ with river streamflow, and thus the annual nitrate, TN, OP, and TP generally were smallest in 2002 and 2012, the driest years, and largest in 2008, the wettest year during the study. The annual variability and trends in TN and TP transport from typical subbasins in the Upper (Upper Winnebago River) and Middle (Wolf Creek) Cedar River Basins are shown in figure 12. There generally was a weak nonsignificant upward trend in the amount of TN transported from the subbasins during 2000-15. One explanation of this weak trend may be that rainfall, and subsequently runoff, was greater in the second half of the study period than in the first half (figs. 4 and 5). Similar to the lack of a trend in TP concentrations in the Cedar River Basin (Wang and others, 2016), there was no change in the amount of TP transported from most subbasins during 2000-15.

TP transport from most subbasins did not change from 2000 through 2015, with two notable exceptions. A statistically significant $(p<0.05)$ linear increase in TP load (fig. 13) from 2000 to 2015 was in two main stem Cedar River subbasins that include the Waterloo and Cedar Rapids urban areas. Based on the linear trend, the estimated (fig. 13) annual load transported from the Main Stem Middle Cedar River subbasin increased from 106 tons in 2002 to 673 tons in 2014. The estimated annual load transported from the Lower Cedar River subbasin increased from 485 tons in 2001 to 1,560 tons in 2014 (fig. 13). The annual rate of increase was about 8 percent per year from both subbasins.

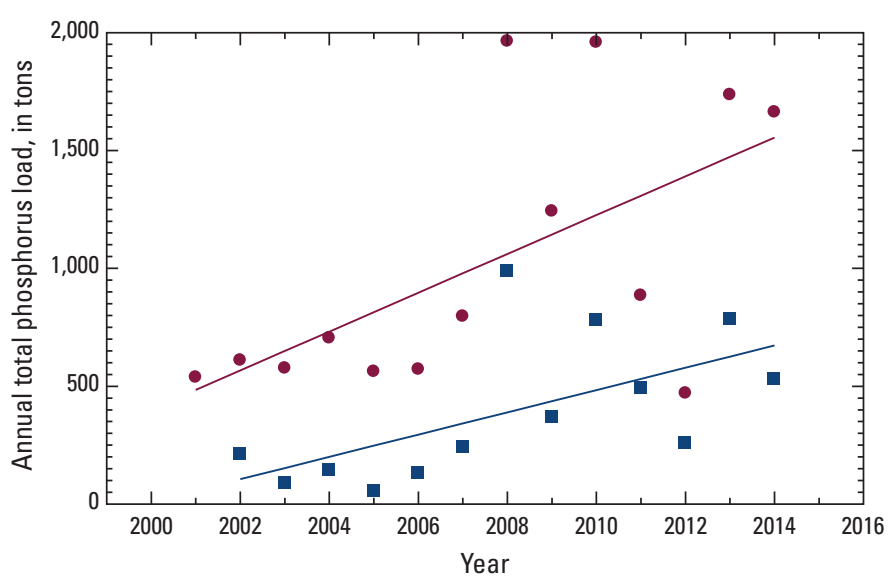

EXPLANATION

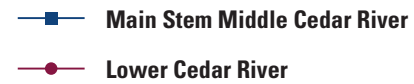

Figure 13. The trend in the transport of total phosphorus from the Main Stem Middle Cedar River and Lower Cedar River subbasins, 2000-15. [Main Stem Middle Cedar River; $R^{2}=0.37$; annual load = year (47.243)-94,474; Lower Cedar River coefficient of determination $\left(R^{2}\right)=0.36$; annual load = year $\left.(82.341)-164,279\right]$
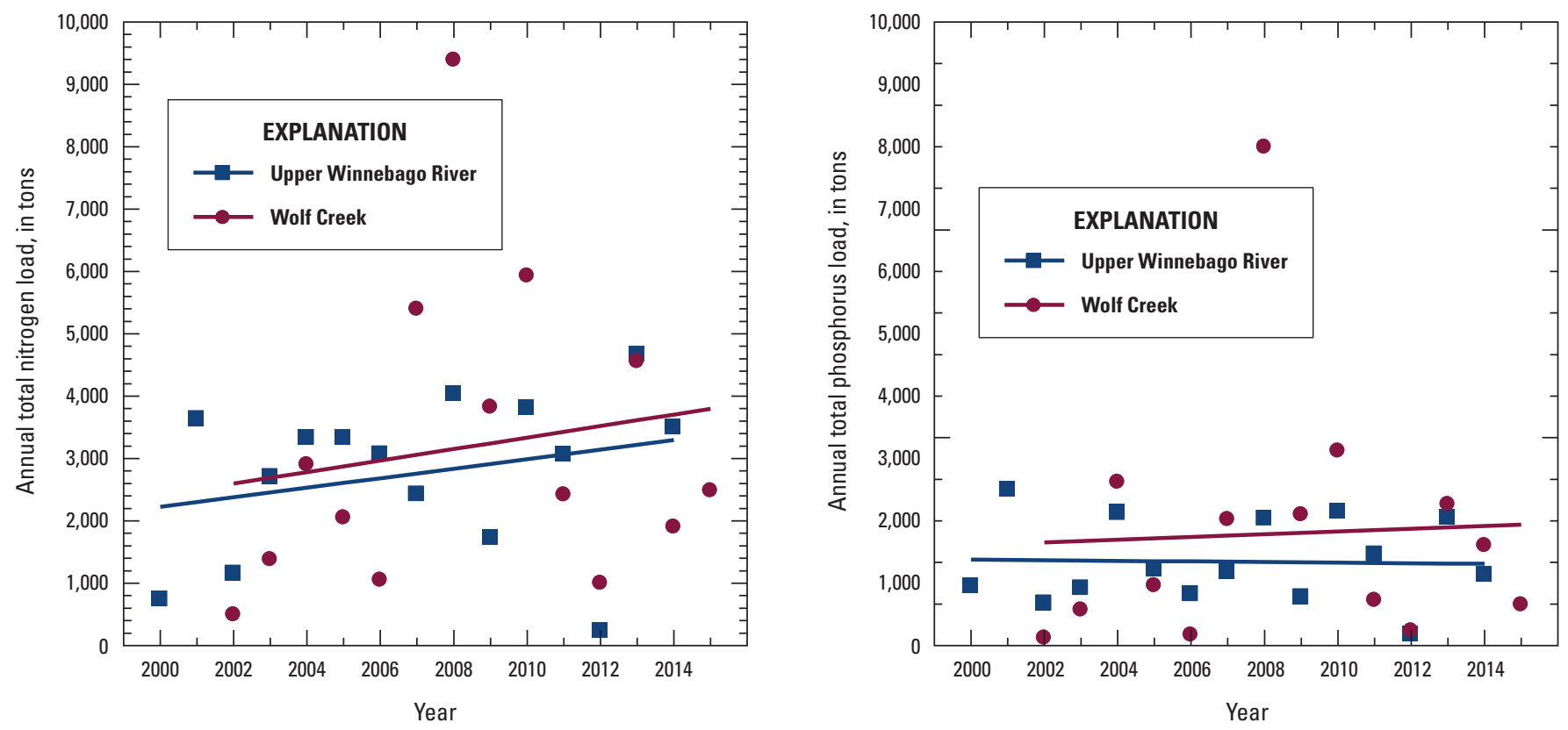

Figure 12. The trend in estimated annual total nitrogen and total phosphorus loads in the Upper Winnebago River and Wolf Creek from 2000 through 2015. 
The increasing trend in TP load may be described more accurately by a step trend rather than a linear trend. Precipitation in the Cedar River Basin (fig. 4) was significantly greater during the second half of the study than the first half. The annual TP transport was significantly greater $(p<0.05$, Wilcoxon rank sum) from the Main Stem Middle Cedar River and Lower Cedar River subbasins during the second half (2008-15) than during the first half (2000-7) of the study period. The average annual TP load transported from the Main Stem Middle Cedar River subbasin more than quadrupled from 144 tons during the first half of the study to 600 tons during the second half of the study (fig. 14). Similarly, the average annual TP load transported from the Lower Cedar River subbasin more than doubled from 623 tons during the first half of the study to 1,420 tons during the second half of the study (fig. 14). The average annual runoff from both subbasins during the second half of the study was about twice the runoff during the first half of the study.

\section{Transport in the Main Stem Upper Cedar River Subbasin}

Because of the shorter period of available data for the Minnesota Cedar River subbasin, nutrient load and yields for the Main Stem Upper Cedar River subbasin were compared with those in other subbasins. Water-quality and stream discharge data for the Minnesota Cedar River subbasin were only available from 2007 to 2015 . This 9 -year dataset is sufficient to partition out nutrient loads from the nested Minnesota Cedar River subbasin from loads in the Main Stem Upper Cedar River subbasin. The Minnesota Cedar River subbasin is 26.7 percent of the area of the Cedar River Basin upstream from the Charles City, Iowa (Main Stem Upper Cedar River) sampling site.

The Minnesota Cedar River subbasin on average contributed about one-third of the nitrogen and between 44 and 65 percent of the phosphorus load from the Main Stem Upper

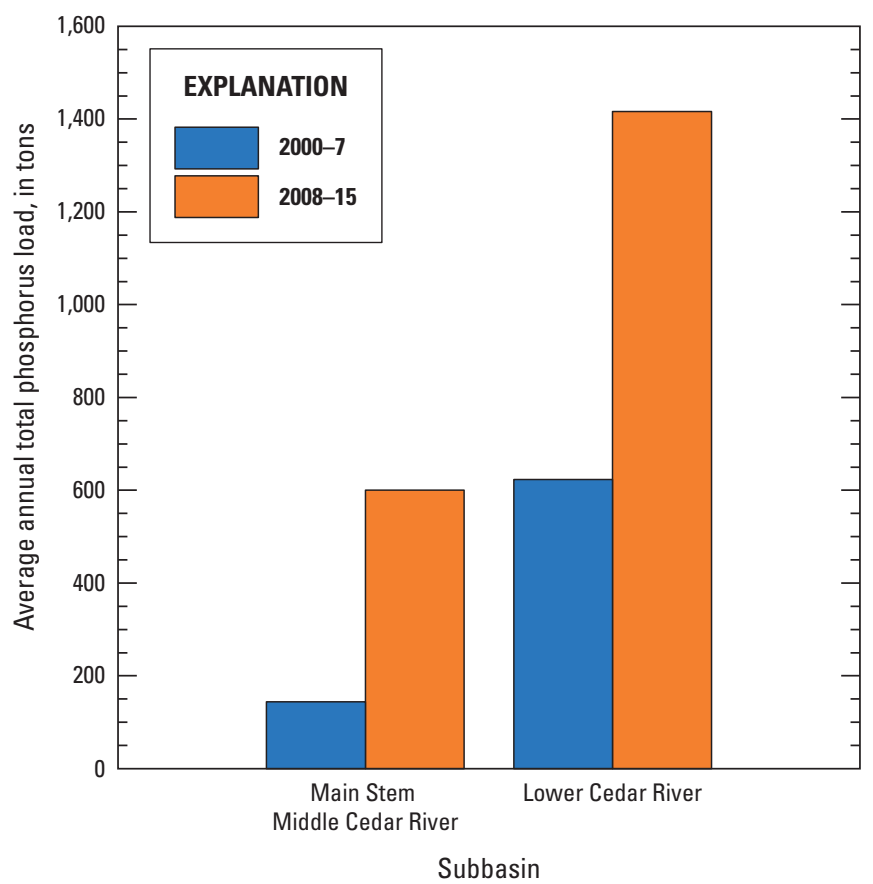

Figure 14. A comparison of the average annual total phosphorus load between the first half (2000-7) and second half (2008-15) of the study in the Main Stem Middle Cedar and Lower Cedar River Basins. Annual loads are significantly greater during the second half of the study.

Cedar River subbasin (table 11). The average annual loss (yield) of TN and nitrate in pounds per acre was not substantially different between the two subbasins (table 11). Loss of phosphorus was greatest in the Minnesota Cedar River subbasin. The average annual OP yield in the Minnesota Cedar River subbasin was 3.6 times greater than from the Main Stem Upper Cedar River subbasin. The average annual TP yield in the Minnesota Cedar River subbasin was 1.4 times greater than from the Main Stem Upper Cedar River subbasin.

Table 11. Summary of annual nutrient load and yield in Minnesota Cedar River and Main Stem Upper Cedar River subbasins, $2007-15$.

[N, nitrogen: P, phosphorus]

\begin{tabular}{|c|c|c|c|c|c|c|c|c|c|c|}
\hline $\begin{array}{c}\text { Map } \\
\text { identifier } \\
\text { (fig. 6) }\end{array}$ & Subbasin name & Constituent & \multicolumn{4}{|c|}{ Load, in tons } & \multicolumn{4}{|c|}{ Yield, in pounds per acre } \\
\hline \multirow[t]{4}{*}{$\mathrm{MNC}$} & \multirow{4}{*}{$\begin{array}{l}\text { Minnesota Cedar } \\
\text { River }\end{array}$} & Nitrate-N & 563 & 3,120 & 3,010 & 5,800 & 4.41 & 24.5 & 23.6 & 45.4 \\
\hline & & Total nitrogen & 658 & 3,610 & 3,410 & 6,300 & 5.16 & 28.3 & 26.7 & 49.4 \\
\hline & & Orthophosphate-P & 30.4 & 73.0 & 71.4 & 118 & 0.238 & 0.572 & 0.559 & 0.924 \\
\hline & & Total phosphorus & 50.3 & 124 & 126 & 176 & 0.394 & 0.979 & 1.02 & 1.37 \\
\hline \multirow[t]{4}{*}{ MUC } & \multirow{4}{*}{$\begin{array}{l}\text { Main Stem } \\
\text { Upper Cedar } \\
\text { River }\end{array}$} & Nitrate-N & 1,130 & 6,050 & 5,160 & 11,300 & 5.08 & 27.1 & 23.1 & 50.7 \\
\hline & & Total nitrogen & 1,270 & 6,780 & 5,900 & 12,600 & 5.68 & 30.4 & 26.4 & 56.5 \\
\hline & & Orthophosphate-P & 0.0 & 40.0 & 35.0 & 81.0 & 0.000 & 0.179 & 0.155 & 0.364 \\
\hline & & Total phosphorus & 12.0 & 156 & 155 & 284 & 0.055 & 0.701 & 0.694 & 1.27 \\
\hline
\end{tabular}




\section{Relation Between Nutrient Transport and Runoff}

Rainfall, and subsequent runoff, has been a major factor in the transport of nutrients from the landscape. Increasing amounts of runoff yield increasing amounts of nitrogen and phosphorus. Generally, the smallest nitrogen and phosphorus yielding subbasins corresponded to the smallest stream runoff (table 10), indicating that rainfall also was an important factor in the transport of these nutrients from the Cedar River Basin in Iowa and Minnesota from 2000 to 2015.

Rainfall that was extremely variable from year to year during the study period (fig. 4) generated streamflow (runoff) that ranged from near record lows in 2012 to record highs in 2008. The average annual runoff for this period thus represents a wide range of flow conditions. As with rainfall, runoff generally increases from the northwest to the southeast in the Cedar River Basin (fig. 15). The average annual runoff increased from 10.18 in. from the Shell Rock River subbasin to 13.01 in. from the Lower Cedar River subbasin (table 10).

In the Cedar River Basin, the relation between annual runoff and annual TN and TP yields was highly variable but was statistically significant $(p<0.05)$ in all subbasins during the study period. The relation between runoff and nutrient yield is variable, although the amount of annual nutrient transport increases with increases in annual runoff. An example of the difference in the relation between runoff and TN and TP yields from the Wolf Creek and Upper Winnebago River subbasins is shown in figure 16. Annual runoff in Wolf Creek ranged from $2.27 \mathrm{in.}$ to $30.5 \mathrm{in}$., annual TN yield ranged from $4.73 \mathrm{lb} /$ acre to $89.7 \mathrm{lb} / \mathrm{acre}$, and TP ranged from $0.08 \mathrm{lb} / \mathrm{acre}$ to $5.73 \mathrm{lb} / \mathrm{acre}$. During the same period, the runoff in the Upper Winnebago River ranged from 2.28 in. to 16.5 in., TN ranged from $1.64 \mathrm{lb} /$ acre to $32.1 \mathrm{lb} / \mathrm{acre}$, and TP ranged from $0.09 \mathrm{lb} /$ acre to $1.10 \mathrm{lb} / \mathrm{acre}$ (fig. 16). Annual yields of TN and TP are highly correlated $(p<0.05)$ and are linearly related to annual runoff (table 12). The regression slope of the relation between annual runoff and annual TN and TP yields was significantly $(p<0.05$, ANCOVA) greater for Wolf Creek than for the Upper Winnebago River, which indicates that for a given amount of runoff, more TN or TP was transported from the Wolf Creek subbasin than from the Upper Winnebago River subbasin. Slopes of the regression represent rates of loss (yield) in relation to runoff from each subbasin; for example, the predicted annual TN yield with an annual runoff of $15 \mathrm{in}$. is about 31 percent less from the Upper Winnebago River subbasin $(27.3 \mathrm{lb} / \mathrm{acre})$ than from the Wolf Creek subbasin ( $39.4 \mathrm{lb} / \mathrm{acre})$. Similarly, the predicted annual TP yield with an annual runoff of 15 in. is 46 percent less from the Upper Winnebago River subbasin $(1.00 \mathrm{lb} / \mathrm{acre})$ than from the Wolf Creek subbasin (1.86 lb/acre).

There was a highly correlated, statistically significant $(p<0.05)$ relation between annual runoff and nitrate, TN, OP, and TP in all studied Cedar River subbasins. This relation was not uniform from subbasin to subbasin (fig. 17). Several

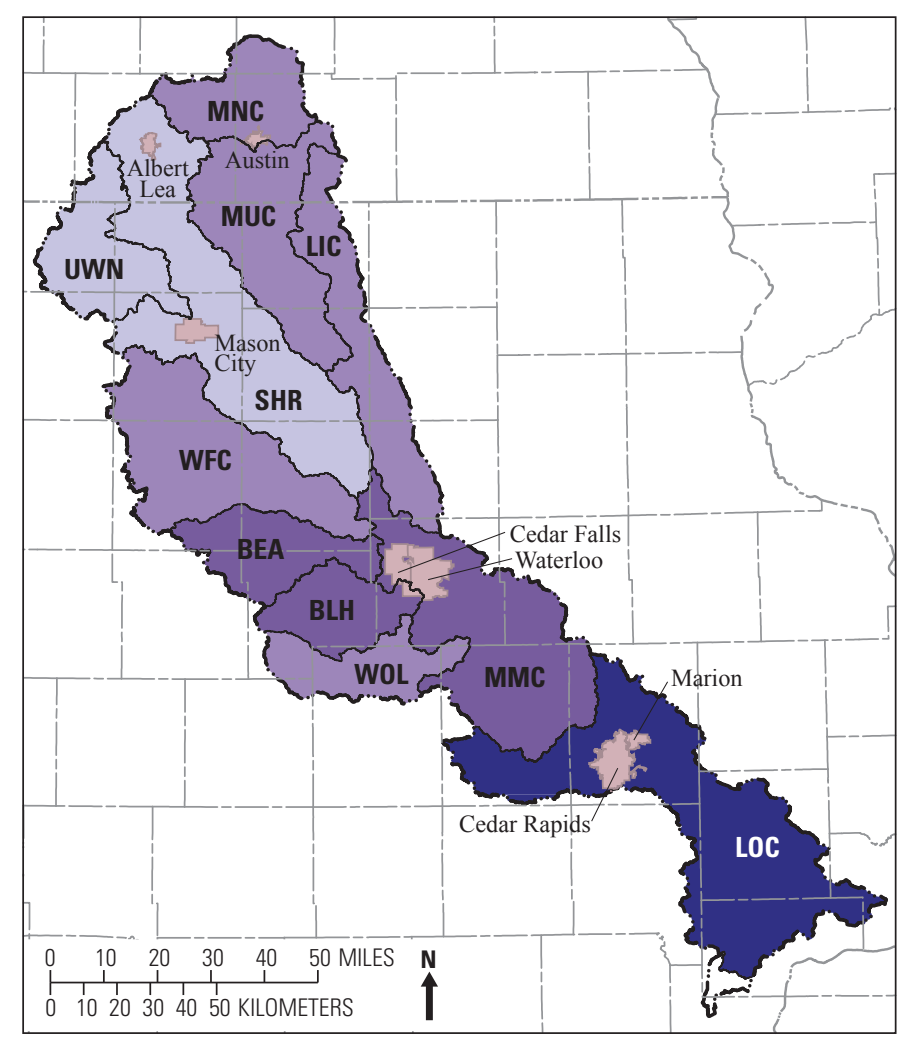

EXPLANATION

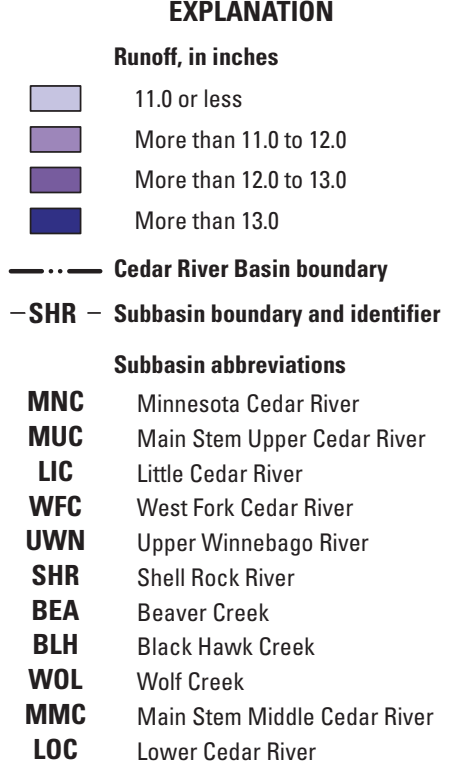

Figure 15. Spatial variability of the average annual stream runoff from long-term monitoring subbasins in the Cedar River Basin, 2000-15.

factors probably affect the runoff/yield relation. Linear regression equations quantifying the relation between annual runoff and the annual yield of nitrate, TN, OP, and TP are listed in table 12. Equations were developed by forcing the regression through the origin; in other words, no stream runoff would result in no nutrient transport. 
Based on the resulting TN/runoff regression slope, subbasins were categorized into three groups. The first group of subbasins that yielded the largest amount of TN for a given amount of runoff (table 12) includes three Middle Cedar River subbasins: Beaver Creek, Black Hawk Creek, and Wolf Creek. A subbasin in the Upper Cedar River, the Main Stem Upper Cedar River, which includes the Minnesota Cedar River subbasin, also was among the top four yielding subbasins. Slopes of the annual TN/runoff regression for this group of subbasins ranged from 2.393 to 2.633 with an average of 2.491 (table 12).

The second group of subbasins includes three from the Upper Cedar River with intermediate annual TN/runoff regression slopes that ranged from 1.819 to 2.182 with an average of 1.997. These subbasins included the Shell Rock River and its nested subbasin, the Upper Winnebago River, and the West Fork Cedar River. The TN yield in relation to runoff from this group of subbasins was significantly ( $p<0.05$, ANCOVA) less than the first group.

The Main Stem Middle Cedar River and the Lower Cedar River along with the Little Cedar River had the smallest regression slopes (table 12). The three subbasins with the smallest TN runoff/yield ratios were from 40 to 60 percent less than the three subbasins with the greatest rates of TN to runoff. These subbasins generally correspond to those with the smallest annual TN loads but do not correspond to subbasins with the smallest runoffs; for example, the Main Stem Middle Cedar River and the Lower Cedar River subbasins had the largest average annual runoffs (table 10) but were two of the lowest yielding subbasins. The lack of correlation between the amount of runoff and the runoff/yield ratio indicates that

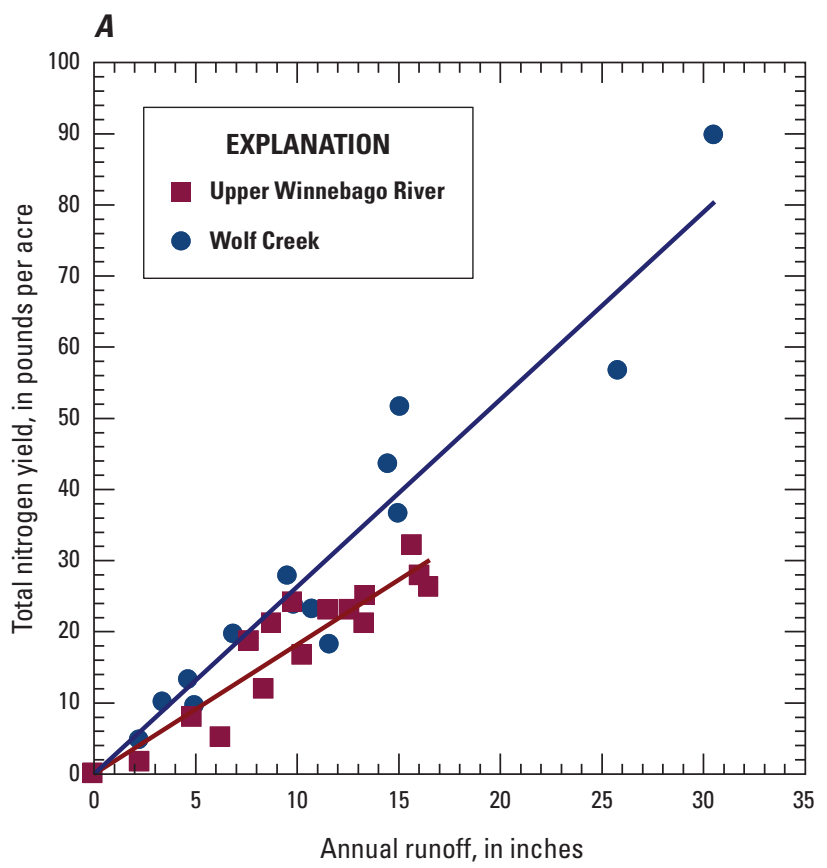

factors other than precipitation contribute to transport of nitrogen from the Cedar River Basin.

The relation between annual runoff and annual TP yield was variable in the 11 long-term monitoring subbasins and generally fell within 4 distinct groups (fig. 17). In the first TP group, the TP yield/runoff regression slope was greater than 0.10 in the Lower Cedar River (0.150) and the Wolf Creek (0.124) subbasins. In the second group, the regression slope ranged from 0.080 to 0.089 . The regression slopes in group 2 were significantly less ( $p<0.05$, ANCOVA) than in group 1. Subbasins in group 2 included, in decreasing order, the Main Stem Middle Cedar River, Beaver Creek, Minnesota Cedar River, and Black Hawk Creek. The third distinct group includes the Main Stem Upper Cedar River, Upper Winnebago, and the Shell Rock subbasins. The regression slopes (table 12) of the group 3 subbasins ranged from 0.065 to 0.068 . The group 3 regression slopes were significantly less $(p<0.05$, ANCOVA) than group 2 slopes, and group 4 includes two subbasins with the smallest slopes that were significantly less ( $p<0.05$, ANCOVA) than the group 3 subbasins. The group 4 subbasins were the West Fork Cedar River and the Little Cedar River subbasins.

Potential differences in source and transport mechanisms may account for the fact that although the Lower Cedar River subbasin had one of the smallest TN runoff/yield ratios, it had the largest TP runoff/yield ratio. Climatic, land use, and geologic factors driving nutrient transport have been documented previously, but analysis of the reason(s) for differences in yields among Cedar River subbasins is beyond the scope of this report.

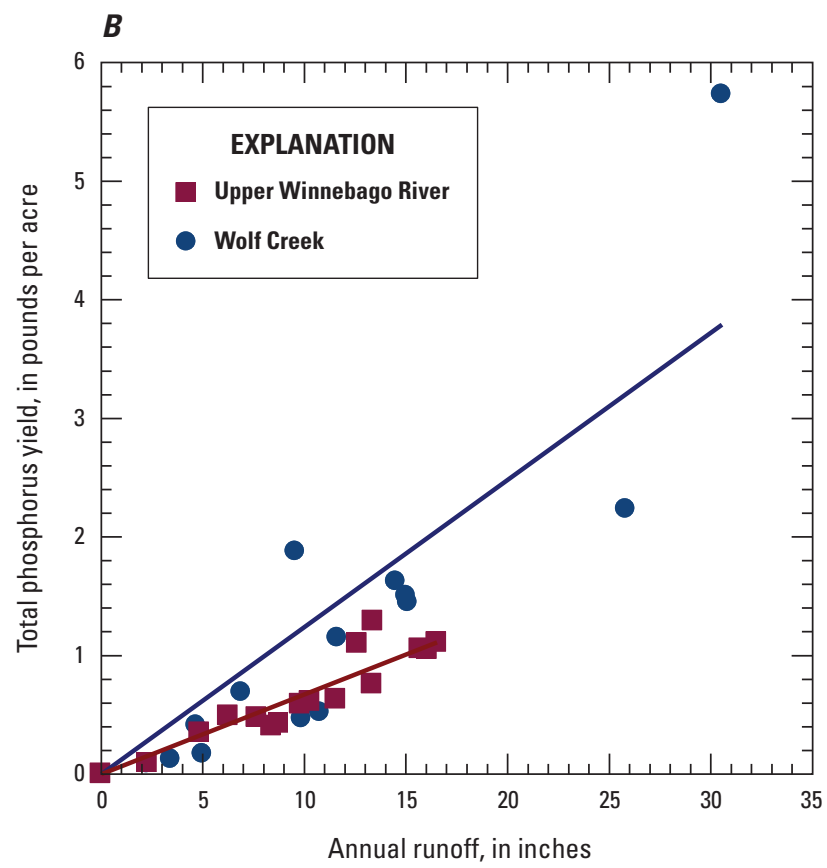

Figure 16. The relation between annual runoff and total nitrogen and total phosphorus yield in the Upper Winnebago River and Wolf Creek subbasins, 2000-15. 
Table 12. Linear relation between annual stream runoff and annual nitrogen and phosphorus yield in Cedar River subbasins, 2000-15.

[Regression forced through the origin; N, nitrogen; P, phosphorus; $R^{2}$, coefficient of determination; $x$ is annual runoff, in inches; $y$ is annual yield, in pounds per acre]

\begin{tabular}{|c|c|c|c|c|c|c|c|c|c|}
\hline \multirow{2}{*}{$\begin{array}{c}\text { Map } \\
\text { identifier } \\
\text { (fig. 6) }\end{array}$} & \multirow{2}{*}{ Subbasin name } & \multicolumn{2}{|r|}{ Nitrate-N } & \multicolumn{2}{|c|}{ Total nitrogen-N } & \multicolumn{2}{|c|}{ Orthophosphate-P } & \multicolumn{2}{|c|}{ Total phosphorus-P } \\
\hline & & $R^{2}$ & Equation & $R^{2}$ & Equation & $R^{2}$ & Equation & $R^{2}$ & Equation \\
\hline $\mathrm{MNC}$ & Minnesota Cedar River & 0.95 & ${ }^{1} y=2.166 x$ & 0.97 & $y=2.51 x$ & 0.98 & $y=0.049 x$ & 0.99 & $y=0.084 x$ \\
\hline MUC & $\begin{array}{l}\text { Main Stem Upper Cedar } \\
\text { River }\end{array}$ & 0.96 & $\begin{array}{l}{ }^{2} y=2.100 x / \\
\quad{ }^{3} y=1.940 x\end{array}$ & 0.97 & ${ }^{2} y=2.393 x$ & 0.97 & ${ }^{2} y=0.025 x$ & 0.97 & ${ }^{2} y=0.068 x$ \\
\hline LIC & Little Cedar River & 0.87 & $y=1.277 x$ & 0.90 & $y=1.433 x$ & 0.63 & $y=0.020 x$ & 0.80 & $y=0.035 x$ \\
\hline UWN & Upper Winnebago River & 0.95 & $y=1.463 x$ & 0.97 & $y=1.819 x$ & 0.91 & $y=0.025 x$ & 0.96 & $y=0.067 x$ \\
\hline SHR & Shell Rock River & 0.96 & $y=1.606 x$ & 0.97 & $y=1.918 x$ & 0.91 & $y=0.021 x$ & 0.94 & $y=0.065 x$ \\
\hline BEA & Beaver Creek & 0.96 & $y=2.157 x$ & 0.97 & $y=2.488 x$ & 0.91 & $y=0.019 x$ & 0.95 & $y=0.087 x$ \\
\hline BLH & Black Hawk Creek & 0.97 & $y=2.206 x$ & 0.98 & $y=2.450 x$ & 0.87 & $y=0.022 x$ & 0.97 & $y=0.080 x$ \\
\hline WOL & Wolf Creek & 0.97 & $y=2.228 x$ & 0.97 & $y=2.633 x$ & 0.92 & $y=0.022 x$ & 0.86 & $y=0.124 x$ \\
\hline
\end{tabular}

${ }^{1}$ Relation for 2007-15.

${ }^{2}$ Entire subbasin upstream from the Cedar River at Charles City, Iowa, 2000-15.

${ }^{3}$ Main Stem Upper Cedar River subbasin (not including Minnesota Cedar River subbasin) 2007-15.

\section{Implications for Nutrient Reduction Strategy}

The periodic monitoring and high frequency waterquality data collected from 2000 to 2015 , along with continuous streamflow, provide data on nutrient transport to evaluate progress on the future implementation of reduction strategies. The Gulf hypoxia nutrient reduction goal is a 45 -percent decrease of TN and TP loads from the 1980-96 baseline load (Mississippi River/Gulf of Mexico Watershed Nutrient Task Force, 2008). An interim goal of a 20-percent nitrogen and phosphorus load reduction by 2025 is a milestone toward reducing the hypoxic zone to less than $5,000 \mathrm{~km}^{2}$ by the year 2035 (U.S. Environmental Protection Agency, 2015). The 2017 reduction goal delays the 45 -percent goal by 20 years from the initial 2008 recommendation (Mississippi River/Gulf of Mexico Watershed Nutrient Task Force, 2008). Progress on nutrient reduction in the Cedar River Basin in Iowa (State of Iowa, 2018) and Minnesota (Minnesota Pollution Control Agency, 2014) will be evaluated based on 1980-96 baseline loads.

Except for sites on the Cedar River at Cedar Falls, Iowa, and at Conesville, Iowa (Goolsby and others, 1999), little water-quality data are available from the Cedar River Basin during the baseline period to directly quantify these loads from smaller subbasins; however, nitrogen and phosphorus loads and yields determined for this study period (2000-15) could provide the basis on which to evaluate future nutrient reduction progress in the Cedar River Basin. The average annual nitrogen and phosphorus loads and yields from the Cedar
River Basin and long-term monitoring subbasins were estimated during 2000-15, when rainfall and runoff varied from extremely dry to extremely wet conditions (figs. 4 and 5). This large hydrologic variability results in a representative estimate of nitrogen and phosphorus transported from the basin during a period when loads were not increasing or decreasing significantly.

The estimated annual average TN reduction, based on the 2000-15 average, from the Cedar River Basin to meet the 45 -percent goal is 23,900 tons. The estimated average annual total nitrogen load reduction to meet the 45-percent goal is 13,500 tons from the Upper Cedar River Basin, 6,700 tons from the Middle Cedar River Basin, and 4,390 tons from the Lower Cedar River Basin. The estimated annual average TP reduction from the Cedar River Basin to meet the 45-percent goal is 1,130 tons. Based on current loads, the estimated average annual TP load reduction from the Upper Cedar River Basin to meet the 45-percent goal is 375 tons; from the Middle Cedar River Basin is 328 tons; and from the Lower Cedar River Basin is 459 tons. Current annual loads and loads for other subbasins in the Cedar River Basin based on a 45 -percent reduction are listed in table 13. Nitrogen and phosphorus reductions to meet the 20-percent and 45-percent goals using the 1980-96 loads are unknown because estimates of baseline loads have not yet (as of early 2018) been calculated.

This report describes runoff transport relations that can be used as a tool to evaluate the nutrient reduction progress. Implementation of the nutrient reduction strategies is expected to alter the runoff/yield relation. A uniform reduction in yield 


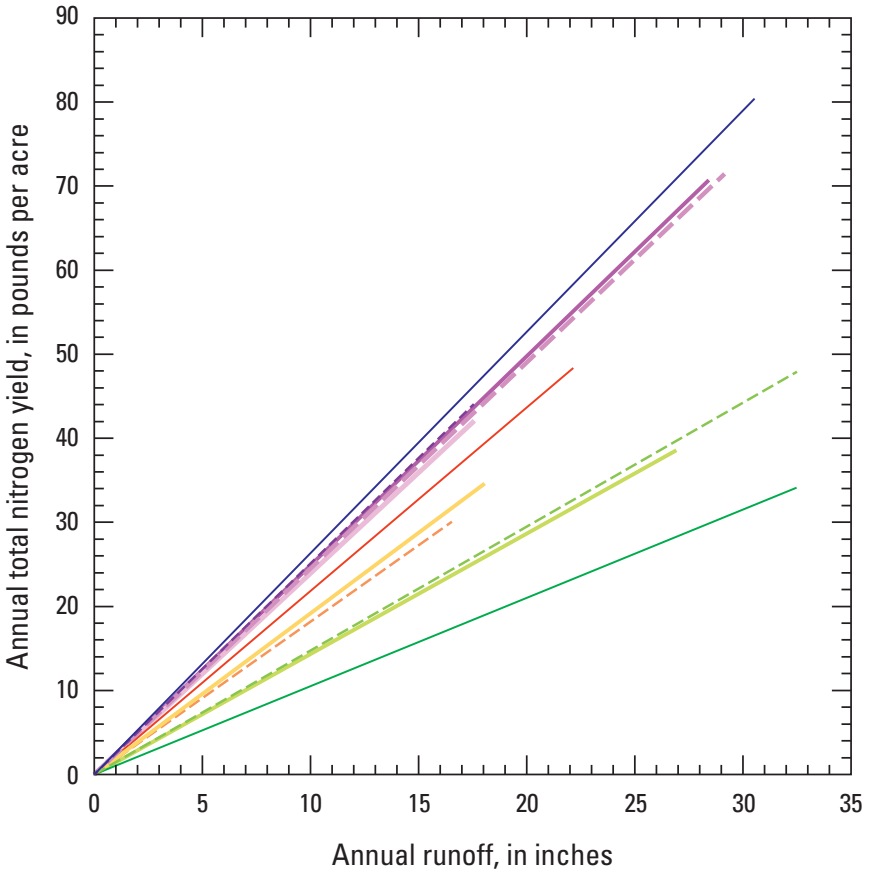

EXPLANATION

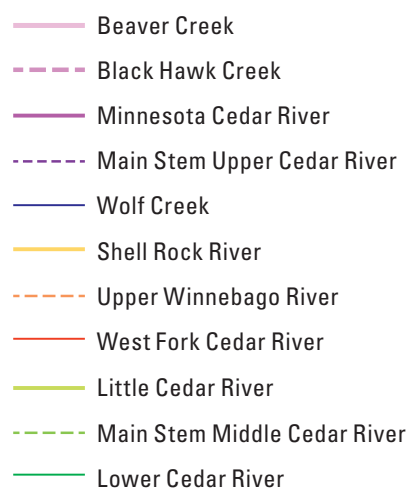

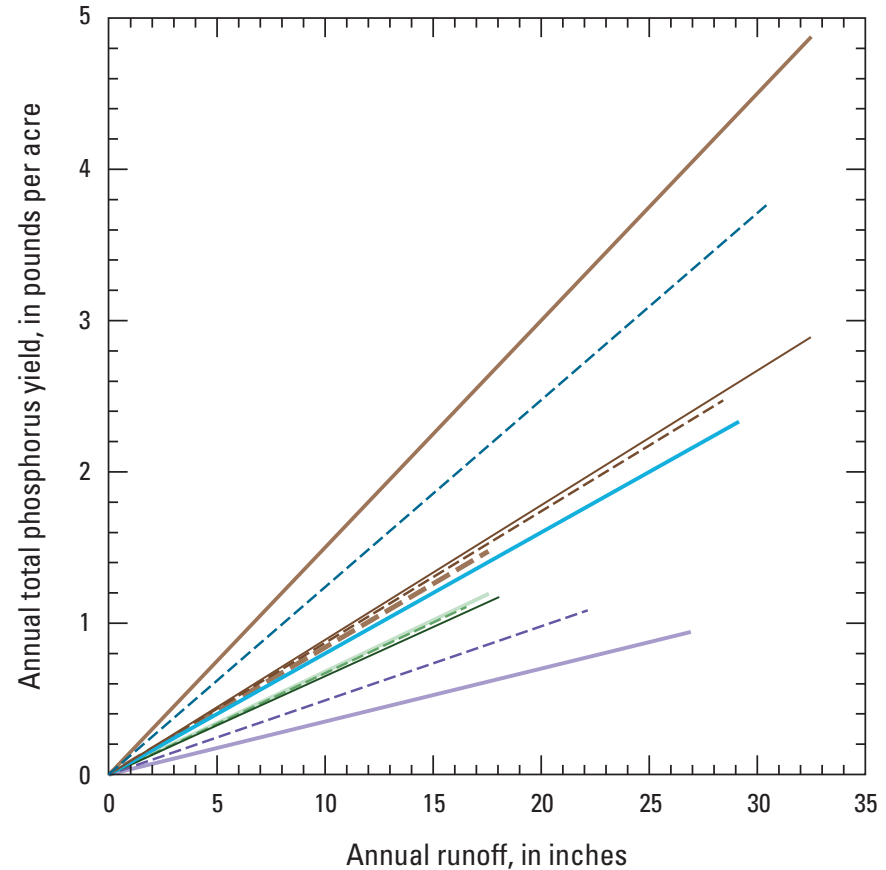

EXPLANATION

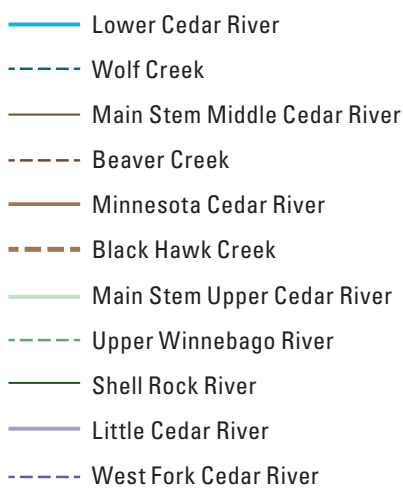

Figure 17. The relation between stream runoff and total nitrogen and total phosphorus yield from long-term monitoring Cedar River subbasins, 2000-15.

over a wide range of hydrologic conditions will result in a smaller slope in the runoff/transport relation. The amount of nutrients transported from a subbasin still would increase with increasing discharge (runoff), although the basin would yield smaller quantities of nitrogen and phosphorus for a given discharge or runoff. An example of the new runoff/yield relation using the yield reduction goals from the Wolf Creek subbasin is shown in figure 18. For the interim 20-percent reduction goal, the estimated TN yield would decrease from the current $29.5 \mathrm{lb}$ /acre to $23.6 \mathrm{lb}$ /acre, generated with $11.22 \mathrm{in}$. of runoff (average for 2000-15, table 10), and would decrease from the current $79.0 \mathrm{lb} /$ acre to $63.0 \mathrm{lb} / \mathrm{acre}$ during a wet (30 in. runoff) year. For the 45 -percent reduction goal, the estimated TN yield would decrease from the current $29.5 \mathrm{lb}$ /acre to $19.2 \mathrm{lb} /$ acre, generated with $11.22 \mathrm{in}$. of runoff (average for 2000-15, table 12), and would decrease from the current $79.0 \mathrm{lb} /$ acre to $51.3 \mathrm{lb} /$ acre during a wet (30 in. runoff) year. A reduction of 20 percent would decrease the annual TP yield from the Wolf Creek subbasin during years with average runoff from the current $1.39 \mathrm{lb} /$ acre to $1.11 \mathrm{lb} /$ acre and would decrease TP yield during a wet (30 in. runoff) year from $3.72 \mathrm{lb} /$ acre to $2.98 \mathrm{lb} /$ acre. A reduction of 45 percent would result in an annual TP yield of $0.90 \mathrm{lb} /$ acre during years with average runoff and would yield $2.42 \mathrm{lb}$ /acre during a wet (30 in. runoff) year. It has been estimated that the full effect of nutrient reduction strategies will require a decade or more to document. By continuing to monitor nitrogen and phosphorus concentrations in the rivers and streams and continuously measuring stream discharge over the next 2 decades or longer, progress towards the final 2035 nutrient reduction goal can be determined by comparing the new runoff/yield relation with the current relation. 
Table 13. Estimated nitrogen and phosphorus loads transported from long-term monitoring Cedar River subbasins to meet 20- and 45-percent nutrient reduction goals.

[Current load average from 2000-15; \%, percent]

\begin{tabular}{|c|c|c|c|c|c|c|c|c|}
\hline \multirow[b]{2}{*}{$\begin{array}{c}\text { Cedar River } \\
\text { Basin }\end{array}$} & \multirow[b]{2}{*}{$\begin{array}{l}\text { Map } \\
\text { identifier } \\
\text { (fig. 6) }\end{array}$} & \multirow[b]{2}{*}{ Subbasin name } & \multicolumn{3}{|c|}{ Average annual total nitrogen } & \multicolumn{3}{|c|}{ Average annual total phosphorus } \\
\hline & & & $\begin{array}{l}\text { Current load } \\
\text { (ton) }\end{array}$ & $\begin{array}{l}\text { Load after } \\
20 \% \text { reduction } \\
\text { (ton) }\end{array}$ & $\begin{array}{l}\text { Load after } \\
45 \% \text { reduction } \\
\text { (ton) }\end{array}$ & $\begin{array}{l}\text { Current load } \\
\text { (ton) }\end{array}$ & $\begin{array}{l}\text { Load after } \\
20 \% \text { reduction } \\
\text { (ton) }\end{array}$ & $\begin{array}{l}\text { Load after } \\
45 \% \text { reduction } \\
\text { (ton) }\end{array}$ \\
\hline \multirow[t]{5}{*}{ Upper Cedar } & $\mathrm{MNC}$ & $\begin{array}{l}\text { Minnesota Cedar } \\
\text { River }\end{array}$ & 3,610 & 2,890 & 1,990 & 124 & 99.4 & 68.4 \\
\hline & MUC & $\begin{array}{l}\text { Main Stem Upper } \\
\text { Cedar River }\end{array}$ & 9,380 & 7,500 & 5,160 & 265 & 212 & 146 \\
\hline & LIC & Little Cedar River & 3,170 & 2,540 & 1,740 & 63.4 & 50.7 & 34.9 \\
\hline & WFC & $\begin{array}{l}\text { West Fork Cedar } \\
\text { River }\end{array}$ & 6,890 & 5,510 & 3,790 & 151 & 121 & 83.0 \\
\hline & UWN & $\begin{array}{l}\text { Upper Winnebago } \\
\text { River }\end{array}$ & 2,760 & 2,210 & 1,520 & 101 & 80.7 & 55.5 \\
\hline \multirow{2}{*}{ Middle Cedar } & WOL & Wolf Creek & 3,200 & 2,560 & 1,760 & 135 & 108 & 74.1 \\
\hline & MMC & $\begin{array}{l}\text { Main Stem } \\
\text { Middle Cedar } \\
\text { River }\end{array}$ & 5,370 & 4,300 & 2,950 & 381 & 305 & 210 \\
\hline Lower Cedar & LOC & $\begin{array}{l}\text { Lower Cedar } \\
\text { River }\end{array}$ & 9,470 & 7,580 & 5,210 & 981 & 785 & 539 \\
\hline
\end{tabular}
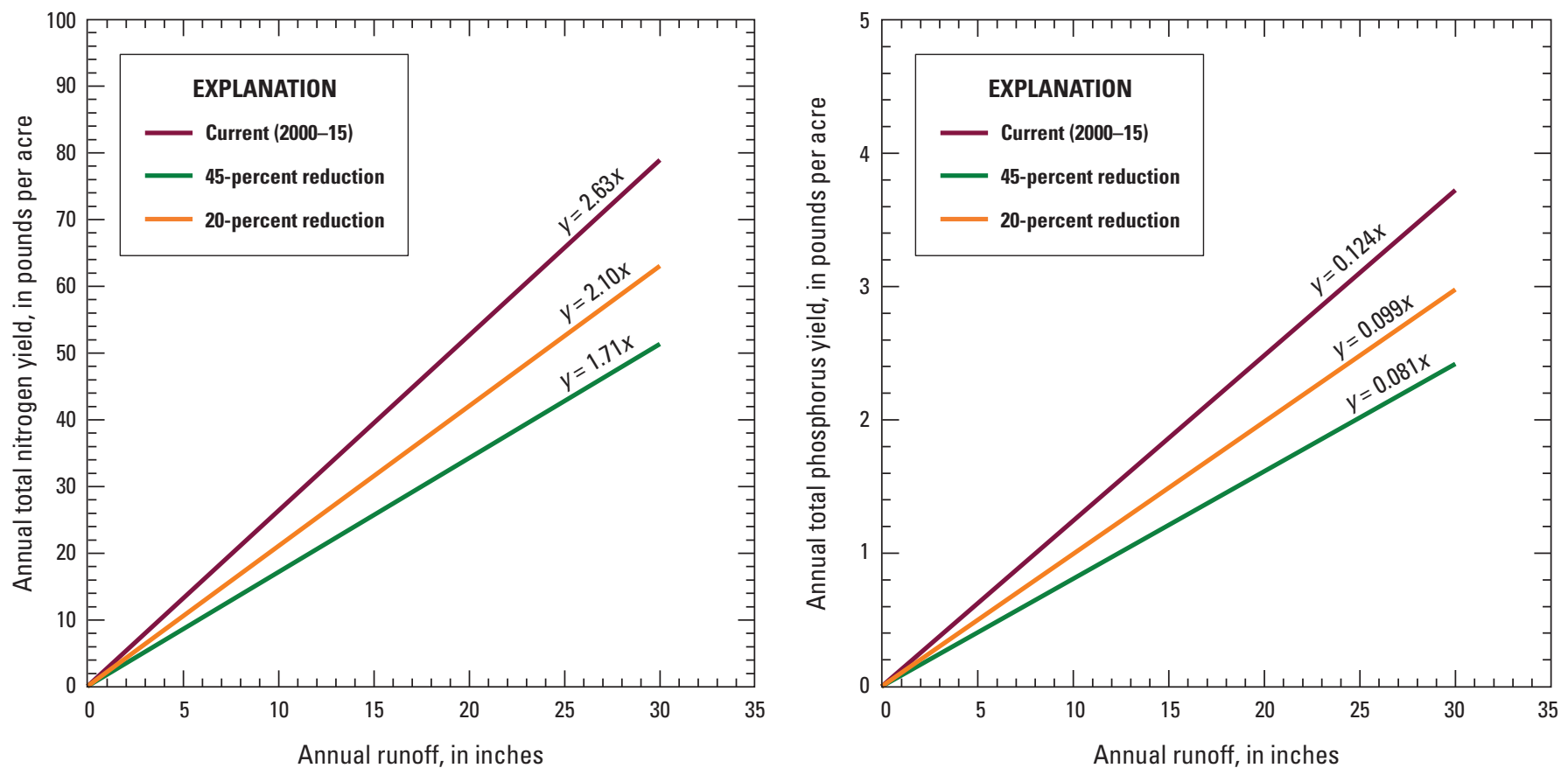

Figure 18. The relation between annual runoff and total nitrogen and total phosphorus yields with current conditions (2000-15) and theoretical 20- and 45-percent yield reductions from the Wolf Creek subbasin. 


\section{Summary and Conclusions}

Nitrate concentrations in the Cedar River in Iowa and Minnesota have increased from an average of less than 1.0 milligram per liter in the early 1900 s to more than 5.0 milligrams per liter in the 2000s and at times have exceeded 10 milligrams per liter and resulted in periodic water-quality impairments of the river. Water from the Cedar River is used for recreation, cooling water, and a source of municipal and industrial supply. Degradation of this resource has limited use of the water at times. Impairments have been recognized, and the States of Iowa and Minnesota have begun implementation of strategies to reduce nutrient transport to the Cedar River and its tributaries.

An assessment of nitrogen and phosphorus currently (2000-15) transported from the Cedar River Basin to the Iowa River was made to document water-quality conditions and to document spatial differences in the origin of nitrogen and phosphorus in the Cedar River Basin in Iowa and Minnesota. Changes in the amount of nitrogen and phosphorus transported were evaluated. Nutrient transport was evaluated in relation to runoff to understand how streamflow affects transport. Data used for this analysis of nitrogen and phosphorus transport in the Cedar River were collected from 2000 to 2015 by the Iowa Department of Natural Resources and the Minnesota Pollution Control Agency as part of their long-term stream and river monitoring programs and by the U.S. Geological Survey as part of six base-flow synoptic studies.

Results of the synoptic studies indicate that nitrogen and phosphorus concentrations varied seasonally during base-flow conditions in the Cedar River Basin. The seasonal differences in concentration and flow resulted in synoptic subbasins yielding more than four times the amount of total nitrogen (TN; average of 75.3 pounds per square mile per day $\left[\mathrm{lb} / \mathrm{mi}^{2} /\right.$ day $]$ ) during spring base-flow conditions than during fall (average of $17.8 \mathrm{lb} / \mathrm{mi}^{2} /$ day) base-flow conditions. Similarly, synoptic subbasins in the Cedar River Basin on average yielded more than three times the amount of total phosphorus during spring $\left(0.92 \mathrm{lb} / \mathrm{mi}^{2} /\right.$ day $)$ than were yielded during fall base-flow conditions $\left(0.29 \mathrm{lb} / \mathrm{mi}^{2} /\right.$ day $)$. During spring and fall base-flow conditions, an average of 90 percent or more of the nitrogen transported was in the dissolved form, nitrate plus nitrite as nitrogen. The proportion of phosphorus transported in the dissolved phase (orthophosphate [OP]) varied from an average of 21 percent during spring to about 45 percent during fall base flow.

Generally, more uniform nitrate and TN were transported from throughout the Cedar River Basin during fall than in spring base-flow conditions. The greatest total phosphorus (TP) yield regardless of season was in several main stem Cedar River subbasins downstream from Waterloo to Cedar Rapids, Iowa. Although streamflow was substantially less, subbasins yielded more TP during dry fall than during normal fall low flow conditions.

The estimated annual average TN and TP load transported from the Cedar River Bain from 2000 to 2015 was
53,100 and 2,510 tons, respectively. Annual nitrogen and phosphorus loads were smallest in 2012 when stream runoff was 4.53 inches and greatest in 2008 when runoff was 24.6 inches. The annual TN load ranged from 15,400 tons to 102,000 tons. Most (about 82 percent) of the nitrogen transported from the Cedar River Basin was in the dissolved nitrate form. The annual TP load averaged 2,510 tons and ranged from 934 to 5,970 tons. An average of 37 percent of the phosphorus was transported as dissolved OP.

Although average annual TN loads were some of the smallest measured, Beaver Creek, Black Hawk Creek, and Wolf Creek subbasins in the Middle Cedar River Basin yielded the largest amount of TN on a per acre basis. These subbasins yielded an annual average of more than 30 pounds per acre (lb/acre), of which more than $25 \mathrm{lb} /$ acre were as nitrate. In contrast, the smallest yielding subbasins, Main Stem Middle Cedar River, the Little Cedar, Upper Winnebago River and Shell Rock River, contributed less than $20 \mathrm{lb} / \mathrm{acre}$ of TN to the Cedar River.

As with TN, the largest average annual load originated from the largest subbasin, but TP loads did not necessarily correlate with the size of the subbasin. A total of four subbasins, the Lower Cedar River, Main Stem Middle Cedar River, Beaver Creek, and Wolf Creek, yielded an average of more than $1.0 \mathrm{lb} / \mathrm{acre}$. In contrast, the average annual TP yield from the Little Cedar River subbasin ( $0.35 \mathrm{lb} / \mathrm{acre})$ was only about 16 percent of the yield from the greatest TP yielding Lower Cedar River subbasin. The dissolved OP part generally was less than 50 percent of the TP load, but this proportion varied throughout the Cedar River Basin.

Annual nitrogen and phosphorus loads varied year to year. There was no linear temporal trend from the 11 subbasins, except for TP from the 2 most downstream main stem Cedar River subbasins, from 2000 to 2015. There was a statistically significant increase in the TP load from 2000 to 2015 in two main stem Cedar River subbasins that include the Waterloo and Cedar Rapids urban areas. The annual rate of increase was about 8 percent per year from both subbasins.

Rainfall and subsequent runoff have been major factors in the transport of nutrients from the landscape. Study results were the same in the Cedar River Basin where there was a highly correlated, statistically significant relation between annual runoff and annual nitrate, TN, OP, and TP yields. However, this relation was not uniform from subbasin to subbasin. Beaver Creek, Black Hawk Creek, and Wolf Creek yielded the largest and the Main Stem Middle Cedar River, the Lower Cedar River, and the Little Cedar River yielded the least amount of TN for a given amount of runoff. The Lower Cedar River and the Wolf Creek subbasins yielded the largest and the West Fork Cedar River and the Little Cedar River subbasins yielded the least amount of TP for a given amount of runoff.

The results of this study describe baseline nutrient transport conditions during 2000-15 that can be used to evaluate progress of the future implementation of reduction strategies in the Cedar River Basin. Using the estimated annual load from 2000 to 2015 as the baseline, an average 
annual reduction of 23,900 tons would be required to meet the 45-percent goal for TN transported from the Cedar River Basin. Based on baseline loads, the estimated average annual TP load reduction from the Cedar River Basin to meet the 45 -percent goal is 1,130 tons. Implementation of the nutrient reduction strategies is expected to alter the runoff/yield relation. By continuing to monitor nitrogen and phosphorus compounds in the rivers and streams and continuously measuring stream discharge at the 11 long-term monitoring sites over the next decade or longer, changes in nutrient transport can be evaluated by comparing the new runoff/yield relation with the current relation.

\section{References Cited}

Becher, K.D., Kalkhoff, S.J., Schnoebelen, D.J., Barnes, K.K., and Miller, V.E., 2001, Water-quality assessment of the Eastern Iowa Basins - Nitrogen, phosphorus, suspended sediment, and organic carbon in surface water, 1996-98: U.S. Geological Survey Water-Resources Investigations Report 2001-4175, 56 p., accessed January 2016 at https://pubs.er.usgs.gov/publication/wri014175.

Boyd, R.A., 1998, Characterizing groundwater flow in the municipal well fields of Cedar Rapids, Iowa, with selected environmental tracers: Journal of the American Water Resources Association, v. 34, no. 3, p. 507-518, accessed April 2018 at https://doi.org/10.1111/j.1752-1688.1998. tb00950.x.

Boyd, R.A., 1999, Groundwater geochemistry in the Seminole Well Field, Cedar Rapids, Iowa: Journal of the American Water Resources Association, v. 35, no. 5, p. 1257-1268. [Also available at https://doi.org/10.1111/j.1752-1688.1999. tb04212.x.]

Christopherson, D., 2014, Water quality trends for Minnesota rivers and streams at milestone sites: Minnesota Pollution Control Agency no. wq-s1-71., accessed June 2017 at https://www.pca.state.mn.us/sites/default/files/wq-s1-71.pdf.

Clarke, F.W., 1924, The composition of the river and lake waters of the United States: U.S. Geological Survey Professional Paper 135, 199 p., accessed April 2018 at https://pubs.er.usgs.gov/publication/pp135.

Dole, R.B., 1909, The quality of surface waters in the United States, part I, analyses of waters east of the one hundredth meridian: U.S. Geological Survey Water-Supply Paper 236, 123 p., accessed April 2018 at https://pubs.er.usgs.gov/ publication/wsp236.
Eash, D.A., O’Shea, P.S., Weber, J.R., Nguyen, K.T., Montgomery, N.L., and Simonson, A.J., 2015, Statistical summaries of selected Iowa streamflow data through September 2013: U.S. Geological Survey Open-File Report 20151214, 18 p., accessed April 2018 at https://doi.org/10.3133/ ofr20151214.

Fishman, M.J., ed., 1993, Methods of analysis by the U.S. Geological Survey National Water Quality Laboratory; determination of inorganic and organic constituents in water and fluvial sediments: U.S. Geological Survey Open-File Report 93-125, 217 p. [Also available at https://pubs.er.usgs.gov/publication/ofr93125.]

Garrett, J.D., 2012, Concentrations, loads, and yields of select constituents from major tributaries of the Mississippi and Missouri Rivers in Iowa, water years 2004-2008: U.S. Geological Survey Scientific Investigations Report 2012-5240, 61 p. [Also available at https://pubs.usgs.gov/ sir/2012/5240.]

Goolsby, D.A., Battaglin, W.A., Lawrence, G.B., Artz, R.S., Aulenbach, B.T., Hooper, R.P., Keeney, D.R., and Stensland, G.J., 1999, Flux and sources of nutrients in the Mississippi-Atchafalaya River Basin-Topic 3 report for the integrated assessment on hypoxia in the Gulf of Mexico: National Oceanic and Atmospheric Administration Coastal Ocean Program, Decision Analysis Series no. 17, 137 p., accessed April 2018 at https://aamboceanservice.blob.core. windows.net/oceanservice-prod/products/hypox_t3final.pdf.

Goolsby, D.A., Battaglin, W.A., Aulenbach, B.T., and Hooper, R.P., Nitrogen input to the Gulf of Mexico: Journal of Environmental Quality, vol. 30. no. 2, p. 329-336, accessed July 2018 at https://dl.sciencesocieties.org/publications/jeq/ pdfs/30/2/329.

Helsel, D.R., and Hirsch, R.M., 2002, Statistical methods in water resources: U.S. Geological Survey Techniques of Water-Resources Investigations, book 4, chapter A3, 522 p., accessed July 2018 at https:/pubs.usgs.gov/twri/twri4a3/ html/toc.html.

Hershey, H.G., 1955, Quality of surface waters of Iowa 18861954; Iowa Geological Survey Water Supply Bulletin no. 5, Iowa City, Iowa, 351 p.

Hirsch, R.M., 1979, An evaluation of some record reconstruction techniques: Water Resources Research, v. 15, no. 6, p. 1781-1790., accessed December 2016 at https://doi.org/10.1029/WR015i006p01781.

Hirsch, R.M., 2014, Large biases in regression-based constituent flux estimates - Causes and diagnostic tools: Journal of the American Water Resources Association, v. 50, no. 6, p. 1401-1424., accessed April 2018 at https://doi.org/10.1111/jawr.12195. 
Hirsch, R.M., and De Cicco, L.A., 2015, User guide to Exploration and Graphics for RivEr Trends (EGRET) and dataRetrieval - R packages for hydrologic data (version 2.0, February 2015): U.S. Geological Survey Techniques and Methods, book 4, chap. A10, 93 p., accessed April 2018 at https://pubs.er.usgs.gov/publication/tm4A10.

Iowa Department of Agriculture and Land Stewardship, Iowa Department of Natural Resources, and Iowa State University College of Agriculture and Life Sciences, 2014, Iowa nutrient reduction strategy-A science and technology-based framework to assess and reduce nutrients to Iowa waters and the Gulf of Mexico: Iowa State University web page, accessed August 16, 2017, at http://www.nutrientstrategy.iastate.edu/sites/default/files/ documents/NRSfull-141001.pdf.

Iowa Department of Natural Resources, 2006, Total maximum daily load for nitrate, Cedar River, Linn County, Iowa: Iowa Department of Natural Resources Watershed Improvement Section, 55 p., accessed April 2018 at http://www.iowadnr.gov/Portals/idnr/uploads/water/ watershed/tmdl/files/final/cedarriver.pdf.

Iowa Natural Resources Council, 1955, An inventory of water resources and water problems Iowa-Cedar River Basin Iowa: Des Moines, Iowa, Iowa Natural Resources Council Bulletin no. 3, 94 p.

Jones, C.S., Davis, C.A., Drake, C.W., Schilling, K.E., Debionne, S.H.P., Gilles, D.W., Demir, D. and Weber, L.J., 2017, Iowa statewide stream nitrate load calculated using in situ sensor network: Journal of the American Water Resources Association, pp. 1-16.

Lee, C.J., Hirsch, R.M., Schwarz, G.E., Holtschlag, D.J., Preston, S.D., Crawford, C.G., and Vecchia, A.V., 2016, An evaluation of methods for estimating decadal stream loads: Journal of Hydrology, v. 542, p. 185-203, accessed April 2018 at https://doi.org/10.1016/j.jhydrol.2016.08.059.

Linhart, S.M., Nania, J.F., Sanders, C.L., Jr., and Archfield, S.A., 2012, Computing daily mean streamflow at ungaged locations in Iowa by using the Flow Anywhere and Flow Duration Curve Transfer statistical methods: U.S. Geological Survey Scientific Investigations Report 2012-5232, 50 p., accessed April 2018 at https://pubs.usgs.gov/ sir/2012/5232/.

Littin, G.R., 2012, Selected water-quality data from the Cedar River and Cedar Rapids well fields, Cedar Rapids, Iowa, 2006-10: U.S. Geological Survey Data Series 657, 32 p., accessed June 2016 at https://pubs.usgs.gov/ds/657/pdf/ ds657.pdf.
Littin, G.R., and Schnoebelen, D.J., 2010, Selected waterquality data from the Cedar River and Cedar Rapids well fields, Cedar Rapids, Iowa, 1999-2005: U.S. Geological Survey Data Series 494, 52 p., accessed June 2016 at https://pubs.usgs.gov/ds/494/pdf/ds494.pdf.

Lorenz, D.L., 2015, smwrBase-An R package for managing hydrologic data, version 1.1.1: U.S. Geological Survey Open-File Report 2015-1202, 7 p., accessed April 2018 at https://doi.org/10.3133/ofr20151202.

Love, S.K., 1956, Quality of surface waters of the United States 1951. Parts 5 and 6, Hudson Bay and Upper Mississippi River basins and Missouri River Basin: U.S. Geological Survey Water-Supply Paper 1198, 586 p., accessed June 2016 at https://pubs.er.usgs.gov/publication/wsp1198.

McDonald, J.H., 2014, Handbook of Biological Statistics (3rd ed.), Sparky House Publishing, Baltimore, Maryland, p. 220-228, accessed July 2018 at http://www.biostathandbook.com/HandbookBioStatThird. pdf.

Midwestern Regional Climate Center, 2015, Welcome to the cli-MATE database: Midwestern Regional Climate Center web page, accessed April 2018 at http://mrcc.isws.illinois.edu/CLIMATE/.

Minnesota Pollution Control Agency, 2012, Cedar River watershed monitoring and assessment report: Minnesota Pollution Control Agency no. wq-ws3-07080201b, 101 p., accessed November 2015 at https://www.pca.state.mn.us/ sites/default/files/wq-ws3-07080201b.pdf.

Minnesota Pollution Control Agency, 2014, The Minnesota nutrient reduction strategy: Minnesota Pollution Control Agency no. wq-s1-80, 348 p., accessed August 2017 at https://www.pca.state.mn.us/sites/default/files/wq-s1-80.pdf.

Minnesota Pollution Control Agency, 2015, Watershed Pollutant Load Monitoring Network (WPLMN) - Surface water quality sampling: Minnesota Pollution Control Agency no. wq-cm1-02, 21 p., accessed April 2018 at https://www.pca.state.mn.us/sites/default/files/ wq-cm1-02.pdf.

Mississippi River/Gulf of Mexico Watershed Nutrient Task Force, 2008, Gulf hypoxia action plan 2008 for reducing, mitigating, and controlling hypoxia in the Northern Gulf of Mexico and improving water quality in the Mississippi River Basin: U.S. Environmental Protection Agency web page, accessed September 2017 at https://www.epa.gov/ ms-htf/gulf-hypoxia-action-plan-2008.

Mosley, L.M., 2015, Drought impacts on the water quality of freshwater systems; review and integration: Earth-Science Reviews, v. 140, p. 203-214, accessed February 2017 at https://doi.org/10.1016/j.earscirev.2014.11.010. 
O’Dell, ed., 1993a, Method 351.2-Determination of total Kjeldahl nitrogen by semi-automated colorimetry (ver. 2.0): U.S. Environmental Protection Agency Inorganic Chemistry Branch, 14 p., accessed October 12, 2016, at https://www.epa.gov/sites/production/files/2015-08/ documents/method_351-2_1993.pdf.

O'Dell, ed., 1993b, Method 353.2-Determination of nitrate-nitrite nitrogen by automated colorimetry: U.S. Environmental Protection Agency Inorganic Chemistry Branch, 14 p., accessed October 12, 2016, at https://www.epa.gov/sites/production/files/2015-08/ documents/method_353-2_1993.pdf.

O'Dell, ed., 1993c, Method 365.1-Determination of phosphorus by semi-automated colorimetry: U.S. Environmental Protection Agency Inorganic Chemistry Branch, 14 p., accessed October 12, 2016, at https://www.epa.gov/sites/ production/files/2015-08/documents/method_365-1_1993. pdf.

Patton, C.J., and Kryskalla, J.R., 2011, Colorimetric determination of nitrate plus nitrite in water by enzymatic reduction, automated discrete analyzer methods: U.S. Geological Survey Techniques and Methods, book 5, chap. B8, 34 p., accessed April 2018 at https://pubs.usgs.gov/tm/05b08/.

Patton, C.J., and Truitt, E.P., 2000, Methods of analysis by the U.S. Geological Survey National Water Quality Laboratory-Determination of ammonium plus organic nitrogen by a Kjeldahl digestion method and an automated photometric finish that includes digest cleanup by gas diffusion: U.S. Geological Survey Open-File Report 00-170, 31 p., accessed April 2018 at https://nwql.usgs.gov/Public/pubs/ OFR00-170.pdf.

Paulsen, C.G., 1950, Quality of surface waters of the United States, 1946: U.S. Geological Survey Water Supply Paper 1050, 486 p., accessed January 2016 at https://pubs.er.usgs.gov/publication/wsp1050.

Paulsen, C.G., 1953, Quality of surface waters of the United States, 1949-Parts 1-6: U.S. Geological Survey Water Supply Paper 1162, 662 p., accessed June 2016 at https://pubs.er.usgs.gov/publication/wsp1162.

Pellerin, B.A., Bergamaschi, B.A., Downing, B.D., Saraceno, J.F., Garrett, J.D., and Olsen, L.D., 2013, Optical techniques for the determination of nitrate in environmental watersGuidelines for instrument selection, operation, deployment, maintenance, quality assurance, and data reporting: U.S. Geological Survey Techniques and Methods, book 1-D5, 37 p., accessed April 2018 at https://pubs.er.usgs.gov/ publication/tm1D5.

Prior, J.C., 1991, Landforms of Iowa: Iowa City, Iowa, University of Iowa Press, 153 p.
Ries, K.G., III, Guthrie, J.G., Rea, A.H., Steeves, P.A., and Stewart, D.W., 2008, StreamStats-A water resources web application: U.S. Geological Survey Fact Sheet 20083067, 6 p., accessed April 2018 at https://pubs.usgs.gov/ fs $/ 2008 / 3067 /$.

Runkel, R.L., Crawford, C.G., and Cohn, T.A., 2004, Load Estimator (LOADEST): A FORTRAN Program for Estimating Constituent Loads in Streams and Rivers: U.S. Geological Survey Techniques and Methods Book 4, Chapter A5, 69 p., accessed July 2018 at https://pubs.usgs.gov/tm/2005/ tm4A5/.

Schilling, K.E., Jones, C.S., Wolter, C.F., Liang, X., Zhang, Y.K., Seeman, A., Isenhart, T., Schnoebelen, D., and Skopec, M., 2017a, Variability of nitrate-nitrogen load estimation results will make quantifying load reduction strategies difficult in Iowa: Journal of Soil and Water Conservation, v. 72, no. 4, p. 317-325, accessed April 2018 at https://doi.org/10.2489/jswc.72.4.317.

Schilling, K.E., Sea-Won, K., Jones, C.S., and Wolter, C.F., 2017b, Orthophosphorus contributions to TP concentrations and loads in Iowa agricultural watersheds: Journal of Environmental Quality, v. 46, no. 4, p. 828-835, accessed April 2018 at https://doi.org/10.2134/jeq2017.01.0015.

Schulmeyer, P.M., Barnes, K.K., and Squillace, P.J., 1995, Hydrologic data from the Lower Cedar River Basin, Iowa, 1989-91: U.S. Geological Survey OpenFile Report 94-711, 116 p., accessed June 2016 at https://pubs.er.usgs.gov/publication/ofr94711W.

Schulmeyer, P.M., and Schnoebelen, D.J., 1998, Hydrogeology and water quality in the Cedar Rapids area, Iowa, 1992-96: U.S. Geological Survey Water-Resources Investigations Report 97-4261, 77 p., accessed April 2018 at https://pubs.er.usgs.gov/publication/wri974261.

Seaber, P.R., Kapinos, F.P., and Knapp, G.L., 1987, Hydrologic unit maps: U.S. Geological Survey WaterSupply Paper 2294, 63 p., accessed April 2018 at https://pubs.er.usgs.gov/publication/wsp2294.

Squillace, P.J., and Engberg, R.A., 1988, Surface-water quality of the Cedar River basin, Iowa-Minnesota, with emphasis on the occurrence and transport of herbicides, May 1984 through November 1985: U.S. Geological Survey WaterResources Investigations Report 88-4060, 81 p., accessed November 2015 at https://pubs.usgs.gov/wri/1988/4060/ report.pdf.

State of Iowa, 2018, Senate file 512: Iowa Legislature web page, accessed April 2018 at https://www.legis.iowa.gov/ docs/publications/LGE/87/SF512.pdf. 
Turnipseed, D.P., and Sauer, V.B., 2010, Discharge measurements at gaging stations: U.S. Geological Survey Techniques and Methods, book 3, chap. A8, 87 p., accessed April 2018 at https://pubs.usgs.gov/tm/tm3-a $8 /$.

U.S. Census Bureau, 2010, 2010 Census TIGER/Line shapefiles: U.S. Department of Commerce, U.S. Census Bureau web page, accessed April 2018 at https://www.census.gov/ geo/maps-data/data/tiger.html.

U.S. Environmental Protection Agency, 1974, Method 365.4: Phosphorous, Total (Colorimetric, Automated, Block Digester AA II), 6 p., accessed April 2018 at https://www.epa.gov/sites/production/files/2015-08/ documents/method_365-4_1974.pdf

U.S. Environmental Protection Agency, 2015, Mississippi River/Gulf of Mexico Watershed Nutrient Task Force 2015 Report to Congress: U.S. Environmental Protection Agency web page, accessed April 2018 at https://www.epa.gov/ ms-htf/hypoxia-task-force-reports-congress.

U.S. Geological Survey, 1977, Water resources data for Iowa, water year 1976: U.S. Geological Survey Water Data Report IA-76-1, 319 p., accessed April 2018 at https://pubs.er.usgs.gov/publication/wdrIA761.

U.S. Geological Survey, 1978, Water resources data for Iowa, water year 1977: U.S. Geological Survey Water Data Report IA-77-1, 258 p., accessed April 2018 at https://pubs.er.usgs.gov/publication/wdrIA771.

U.S. Geological Survey, 1979, Water resources data for Iowa, water year 1978: U.S. Geological Survey Water Data Report IA-78-1, 256 p., accessed April 2018 at https://pubs.er.usgs.gov/publication/wdrIA781.

U.S. Geological Survey, 1980, Water resources data for Iowa, water year 1979: U.S. Geological Survey Water Data Report IA-79-1, 250 p., accessed April 2018 at https://pubs.er.usgs.gov/publication/wdrIA791.

U.S. Geological Survey, 2006, Collection of water samples (ver. 2.0): U.S. Geological Survey Techniques of WaterResources Investigations, book 9, chap. A4, September 2006, accessed April 2018 at https://pubs.water.usgs.gov/ twri9A.

U.S. Geological Survey, 2017, National Water Information System - Web interface: accessed June 10, 2012, at https://doi.org/10.5066/F7P55KJN.

U.S. Geological Survey, variously dated, National field manual for the collection of water-quality data: U.S. Geological Survey Techniques of Water-Resources Investigations, book 9, chaps. A1-A10, accessed April 2018 at https://pubs.water.usgs.gov/twri9A.
Wang, C., Chan, K.S., and Schilling, K.E., 2016, TP concentration trends in 40 Iowa rivers, 1999 to 2013: Journal of Environmental Quality, v. 45, no. 4, p. 1351-1358, accessed July 2017 at https://doi.org/10.2134/jeq2015.07.0365.

Wilde, F.D., ed., 2004, Cleaning of equipment for water sampling (ver. 2.0): U.S. Geological Survey Techniques of Water-Resources Investigations, book 9, chap. A3, April 2004, accessed April 2018 at https://pubs.water.usgs.gov/ twri9A3/.

Wilde, F.D., and Radtke, D.B., Gibs, J., and Iwatsubo, R.T., eds., 2004 with updates through 2009, Processing of water samples (ver. 2.2): U.S. Geological Survey Techniques of Water-Resources Investigations, book 9, chap. A5, April 2004, accessed April 2018 at https://pubs.water.usgs.gov/ twri9A5/. 



\section{Glossary}

annual runoff The total quantity of water that is discharged ("runs off") from a drainage basin in a year. Refers to the depth to which the drainage area would be covered with water if all the runoff for a given period were distributed uniformly on it.

base flow The sustained flow of a stream in the absence of direct runoff. It includes natural and human-induced streamflows. Natural base flow is sustained largely by groundwater discharge.

load The rate of constituent transport, as measured by dry mass or volume, that passes a cross section in a given time. It is calculated in units of tons per day as follows: concentration (in milligrams per liter) $\times$ discharge (in cubic feet per second) $\times 0.0027$.

subbasin A part of the Earth's surface where a smaller drainage basin forms within a larger drainage basin. synoptic studies Short-term investigations of specific water-quality conditions during selected seasonal or hydrologic periods to provide improved spatial resolution for critical water-quality conditions. For the period and conditions sampled, the studies assess the spatial distribution of selected water-quality constituents in relation to causative factors, such as land use and contaminant sources.

trend A statistical term referring to the direction or rate of increase or decrease in magnitude of the individual members of a time series of data when random fluctuations of individual members are disregarded.

water year The 12-month period October 1 through September 30. The water year is designated by the calendar year in which it ends and which includes 9 of the 12 months. Thus, the year beginning on October 1, 2014, and ending September 30, 2015, is called the "2015 water year." 


\section{Appendix 1. Long-Term Monitoring Data from the Cedar River Basin, lowa and Minnesota.}

Table 1.1. Source of long-term monitoring data.

[USGS, U.S. Geological Survey; STORET, U.S. Environmental Protection Agency Storage and Retrieval System; wtryr, water year (A water year is the 12-month period October 1 through September 30 designated by the calendar year in which it ends); MN, Minnesota; QW, periodic water quality; MPCA, Minnesota Pollution Control Agency; Q, daily stream discharge; IA, Iowa; IADNR, Iowa Department of Natural Resources; --, not applicable]

\begin{tabular}{|c|c|c|c|c|c|c|c|}
\hline $\begin{array}{c}\text { Map } \\
\text { number } \\
\text { (fig. 3) }\end{array}$ & $\begin{array}{c}\text { USGS station } \\
\text { identification } \\
\text { number }\end{array}$ & $\begin{array}{c}\text { STORET } \\
\text { identifica- } \\
\text { tion number }\end{array}$ & Station name & Data & $\begin{array}{l}\text { Watershed } \\
\text { area to gage } \\
\text { area ratio }^{1}\end{array}$ & $\begin{array}{l}\text { Source of } \\
\text { data }\end{array}$ & $\begin{array}{l}\text { Period } \\
\text { of record } \\
\text { (wtryr) }\end{array}$ \\
\hline \multirow[t]{2}{*}{1} & 05457000 & ${ }^{2} \mathrm{~S} 000-001$ & Cedar River near Austin, MN & QW & 1.00 & ${ }^{3} \mathrm{MPCA}$ & $2007-15$ \\
\hline & & & & Q & & ${ }^{4} \mathrm{USGS}$ & $2000-15$ \\
\hline \multirow[t]{2}{*}{2} & 05457700 & 10340001 & Cedar River near Charles City, IA & QW & 1.04 & ${ }^{5} \mathrm{IADNR}$ & $2000-15$ \\
\hline & & & Cedar River at Charles City, IA & Q & & ${ }^{4} \mathrm{USGS}$ & $2000-15$ \\
\hline 3 & & & & Q & & ${ }^{4} \mathrm{USGS}$ & $2000-15$ \\
\hline \multirow[t]{2}{*}{4} & 05458900 & 10070003 & West Fork Cedar River at Finchford, IA & QW & 1.00 & ${ }^{5} \mathrm{IADNR}$ & $2000-15$ \\
\hline & & & & Q & & ${ }^{4} \mathrm{USGS}$ & $2000-15$ \\
\hline 5 & 05459500 & 10170002 & $\begin{array}{l}\text { Winnebago River upstream from } \\
\text { Mason City, IA }\end{array}$ & QW & 0.86 & ${ }^{5} \mathrm{IADNR}$ & 2001-14 \\
\hline 6 & & & & Q & & ${ }^{4} \mathrm{USGS}$ & $2000-15$ \\
\hline \multirow[t]{2}{*}{7} & 05463000 & 10070001 & Beaver Creek near Cedar Falls, IA & QW & 1.14 & ${ }^{5} \mathrm{IADNR}$ & $2000-15$ \\
\hline & & & Beaver Creek at New Hartford, IA & Q & & ${ }^{4}$ USGS & $2000-15$ \\
\hline \multirow[t]{2}{*}{8} & 05463500 & 10070004 & Black Hawk Creek at Waterloo, IA & QW & 1.08 & ${ }^{5} \mathrm{IADNR}$ & $2001-15$ \\
\hline & & & Black Hawk Creek at Hudson, IA & Q & & ${ }^{4} \mathrm{USGS}$ & $2000-15$ \\
\hline \multirow[t]{2}{*}{9} & 05464220 & 10070002 & Wolf Creek at La Porte City, IA & QW & 1.09 & ${ }^{5} \mathrm{IADNR}$ & $2000-15$ \\
\hline & & & Wolf Creek near Dysart, IA & Q & & ${ }^{4} \mathrm{USGS}$ & $2000-15$ \\
\hline 10 & -- & 10570002 & $\begin{array}{l}\text { Cedar River upstream from Cedar Rapids, } \\
\text { IA }\end{array}$ & QW & 0.97 & ${ }^{5} \mathrm{IADNR}$ & 2001-14 \\
\hline
\end{tabular}

${ }^{1}$ Watershed to gage area ratio from Calvin Wolter, Iowa Department of Natural Resources, written communication, April 2016.

${ }^{2}$ Minnesota Pollution Control site identification number.

${ }^{3}$ MPCA data source: https://cf.pca.state.mn.us//eda/.

${ }^{4}$ USGS data source: https://waterdata.usgs.gov/ia/nwis/.

${ }^{5}$ IADNR data source: https://programs.iowadnr.gov/aquia/. 
Table 1.2. Annual nutrient loads in long-term monitoring subbasins, 2000-15.

[N, nitrogen: $\mathrm{P}$, phosphorus]

\begin{tabular}{|c|c|c|c|c|c|c|c|}
\hline \multirow{2}{*}{$\begin{array}{c}\text { Map } \\
\text { identifier } \\
\text { (fig. 6) }\end{array}$} & \multirow{2}{*}{ Subbasin name } & \multirow{2}{*}{ Constituent } & \multirow{2}{*}{$\begin{array}{c}\text { Number of } \\
\text { years }\end{array}$} & \multicolumn{4}{|c|}{ Yearly load, in tons } \\
\hline & & & & Minimum & Mean & Median & Maximum \\
\hline \multirow[t]{4}{*}{$\mathrm{MNC}$} & \multirow[t]{4}{*}{ Minnesota Cedar River } & Nitrate-N & 9 & 563 & 3,120 & 3,010 & 5,800 \\
\hline & & Total nitrogen & 9 & 658 & 3,610 & 3,410 & 6,300 \\
\hline & & Orthophosphate-P & 9 & 30.4 & 73.0 & 71.4 & 118 \\
\hline & & Total phosphorus & 9 & 50.3 & 124 & 126 & 176 \\
\hline \multirow{3}{*}{ MUC } & \multirow{3}{*}{$\begin{array}{l}\text { Main Stem Upper Cedar } \\
\text { River }\end{array}$} & Total nitrogen & 15 & 1,930 & 9,380 & 10,000 & 18,900 \\
\hline & & Orthophosphate-P & 15 & 31.9 & 101 & 110 & 162 \\
\hline & & Total phosphorus & 15 & 62.6 & 265 & 228 & 462 \\
\hline \multirow[t]{2}{*}{ LIC } & \multirow[t]{2}{*}{ Little Cedar River } & Nitrate-N & 15 & 441 & 2,820 & 2,780 & 5,310 \\
\hline & & Total nitrogen & 15 & 639 & 3,170 & 3,360 & 5,700 \\
\hline \multirow{3}{*}{ WFC } & \multirow{3}{*}{ West Fork Cedar River } & Total nitrogen & 16 & 1,120 & 6,890 & 6,190 & 12,400 \\
\hline & & Orthophosphate-P & 16 & 10.2 & 66.7 & 54.6 & 186.1 \\
\hline & & Total phosphorus & 16 & 22.8 & 151 & 133 & 307 \\
\hline \multirow[t]{4}{*}{ UWN } & \multirow[t]{4}{*}{ Upper Winnebago River } & Nitrate-N & 15 & 165 & 2,220 & 2,510 & 3,890 \\
\hline & & Total nitrogen & 15 & 238 & 2,760 & 3,060 & 4,660 \\
\hline & & Orthophosphate-P & 15 & 8.87 & 37.8 & 36.6 & 70.7 \\
\hline & & Total phosphorus & 15 & 13.1 & 101 & 88.5 & 187 \\
\hline \multirow[t]{2}{*}{ SHR } & \multirow[t]{2}{*}{ Shell Rock River } & Nitrate-N & 15 & 788 & 6,790 & 7,180 & 12,900 \\
\hline & & Total nitrogen & 15 & 1,090 & 8,130 & 8,290 & 14,800 \\
\hline \multirow[t]{4}{*}{$\mathrm{BLH}$} & \multirow[t]{4}{*}{ Black Hawk Creek } & Nitrate-N & 14 & 864 & 2,910 & 2,270 & 6,420 \\
\hline & & Total nitrogen & 14 & 933 & 3,210 & 2,470 & 7,270 \\
\hline & & Orthophosphate-P & 14 & 6.29 & 28.8 & 23.7 & 86.5 \\
\hline & & Total phosphorus & 14 & 14.8 & 96.3 & 62.5 & 290 \\
\hline \multirow[t]{4}{*}{ WOL } & Wolf Creek & Nitrate-N & 15 & 456 & 2,640 & 2,190 & 7,420 \\
\hline & & Total nitrogen & 14 & 495 & 3,200 & 2,450 & 9,390 \\
\hline & & Orthophosphate-P & 15 & 4.27 & 26.4 & 24.4 & 75.3 \\
\hline & & Total phosphorus & 14 & 8.93 & 135 & 96.3 & 600 \\
\hline MMC & Main Stem Middle Cedar & Nitrate-N & 14 & $-5,968$ & 4,240 & 5,140 & 8,570 \\
\hline & River & Total nitrogen & 13 & $-5,091$ & 5,370 & 6,230 & 10,800 \\
\hline & & Orthophosphate-P & 13 & -43.5 & 210 & 78.6 & 956 \\
\hline & & Total phosphorus & 13 & 59.9 & 381 & 268 & 891 \\
\hline LOC & Lower Cedar River & Nitrate-N & 16 & $-5,746$ & 6,700 & 6,010 & 18,800 \\
\hline & & Total nitrogen & 15 & $-2,835$ & 9,470 & 8,100 & 23,500 \\
\hline & & Orthophosphate-P & 15 & 70.6 & 370 & 308 & 1,060 \\
\hline & & Total phosphorus & 15 & 345 & 981 & 682 & 2,060 \\
\hline
\end{tabular}


Table 1.3. Annual nutrient yields in long-term monitoring subbasins, 2000-15.

[N, nitrogen: P, phosphorus]

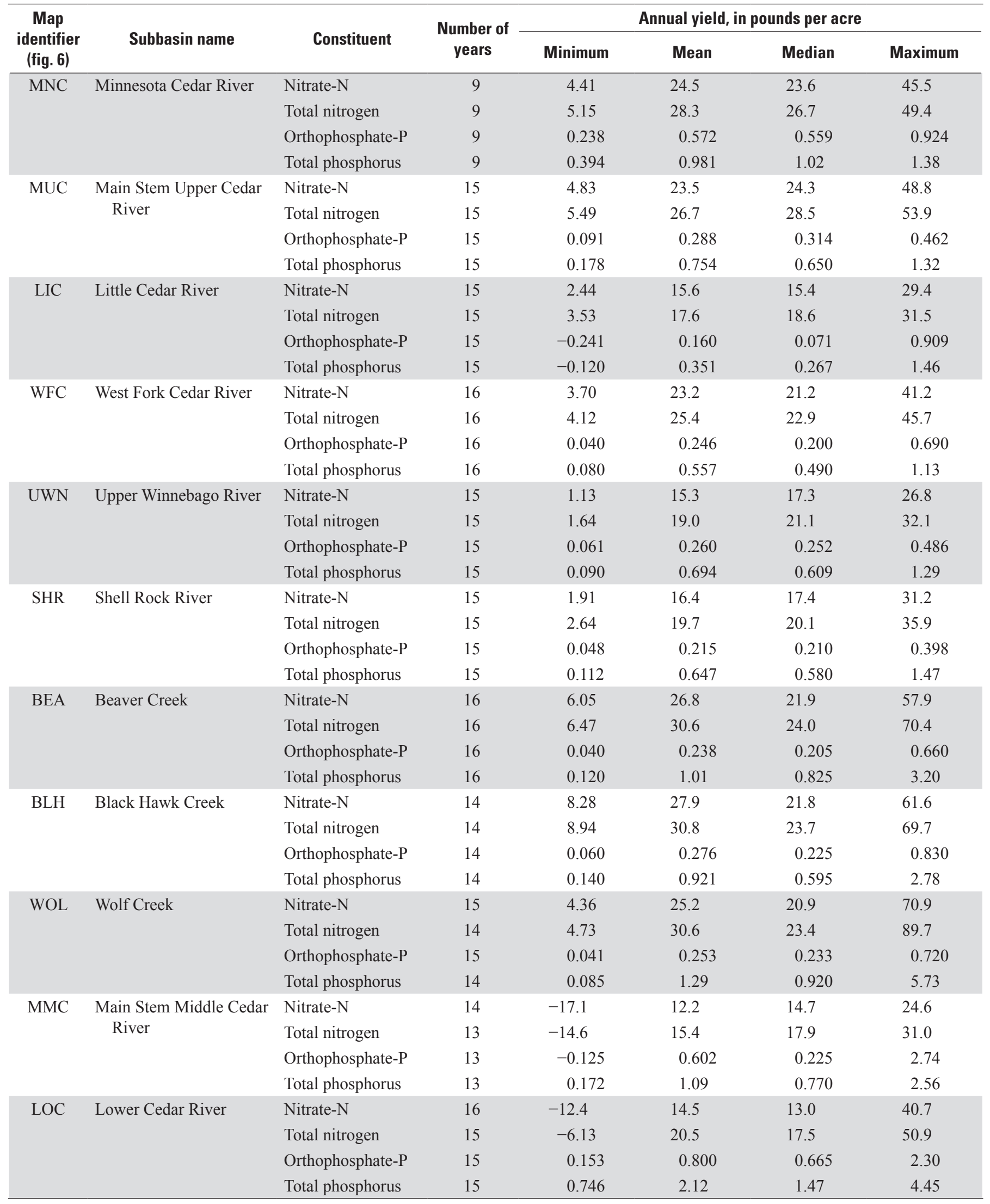


For more information about this publication, contact Director, lowa Water Science Center 400 South Clinton Street

Room 269

lowa City, lowa 52240-4105

(319) 337-4191

For additional information visit https://ia.water.usgs.gov/index.html

Publishing support provided by the

Rolla Publishing Service Center 
